ISABEL MELLO

\title{
METODOLOGIA DE AVALIAÇÃO DA PERMEABILIDADE DENTINÁRIA UTILIZANDO CORANTE E DA REMOÇÃO DO MAGMA DENTINÁRIO ATRAVÉS DE MEV NO MESMO ESPÉCIME RADICULAR
}




\section{Isabel Mello}

Metodologia de avaliação da permeabilidade dentinária utilizando corante e da remoção do magma dentinário através de MEV no mesmo espécime radicular

Tese apresentada à Faculdade de Odontologia da Universidade de São Paulo, para obter o título de Doutor pelo Programa de Pós-Graduação em Ciências Odontológicas

Área de Concentração: Endodontia

Orientador: Prof. Dr. João Humberto Antoniazzi

Co-orientador: Prof. Dr. Jeffrey M. Coil

São Paulo 
Mello I. Metodologia de avaliação da permeabilidade dentinária utilizando corante e da remoção do magma dentinário através de MEV no mesmo espécime radicular [Tese de Doutorado]. São Paulo: Faculdade de Odontologia da USP; 2008.

São Paulo, / / /2008

\section{Banca Examinadora}

1) $\operatorname{Prof}(a)$. $\operatorname{Dr}(a)$.

Titulação:

Julgamento:

Assinatura:

2) $\operatorname{Prof}(a) \cdot \operatorname{Dr}(a)$.

Titulação:

Julgamento:

Assinatura:

3) $\operatorname{Prof}(a) . \operatorname{Dr}(a)$.

Titulação:

Julgamento:

Assinatura:

4) $\operatorname{Prof}(a) \cdot \operatorname{Dr}(a)$.

Titulação:

Julgamento:

Assinatura:

5) $\operatorname{Prof}(a) \cdot \operatorname{Dr}(a)$.

Titulação:

Julgamento:

Assinatura: 
Este trabatho vem conoar toda uma jornada que se inicion quando coloquei mens fés pela primeina vey numa escola. Desde aquela época tomei gosto pelos liveros e comecei a fazer perguntas...e Até aqui, foi uma longar jomada e munca tive medo de enfrentar as tempestades para alcançar mens objelivos. Ëmborav várias vezes as coisas tenham sido dificeis, hoje vejo que valew a pena tov insistido no mew sonho. Valew sim, valew muito a pena. 
Dedico este trabatho ì minha familia.

\section{Papaic mamãe,}

Mais do que para mim, en gostaria que esta conquista fosse motive de orgutho para vocês. Ëste babalho exigine tempo, esforço, abstinência. F̂i dificil sim, mas desta forma a vitória é sempre meltoor. PPara mim não há prêmio maio do que o veconhecimento de vocês dois. Obrigada por terem me proporcionado oportusnidades na minha vida.

\section{Daisy,}

Ninhar irmã mais do que quesida ...en bem sei que sempre loncen for mim. É uma felicidade muilo grande saber que sou moliva de ongulho para você. E̊ você é o men ongulho.

\section{Glaw,}

Tudo o que conquisto na minha vida, pergunto-me: o que ela pensaria? Algora não poderia ser diferente. Émbora não esteja entre nós para comemorar, sua presença é constante. Muilas saudades.

\section{Alos mens sobrinhos: Paulo, Marcelo, Pedro, Gabrielave Tatiana,}

Espero que a minha dedicação aos estudos e a capacidade de perseguir mens sonhos sinvar de exemplo parav vocês. Obrigada por trazerem lug e alegria is nossas vidas.

"Todo o bem que en puder fagers, toda a termuna que en puder demonstrar ar qualquer ser humano, que ew os faça agora, que não os adie ow esqueça, pois não passarei duas vezes pelo mesmo caminho." (Lames Green) 
Nenhuma pessoa é uma itha, embora as pessoas que passem infinilas horas escrevendo uma tese, pow vezes, sintam-se como uma. Ë gostaria de agradecer is pessoas cajo apoio me ajudow a produgiveste babalho. 
Querido Dr. Goão,

$\mathscr{T} \hat{e}$-lo como orientador foi um presente. OH sew apoio e orientação segura foram imprescindiveis parar conchusão deste trabalho. Ë lenho uma estima muito grande por você. Algradeço não somente pelos ensinamentos inspiradores sobre pesquisa, ensino e Endodontia, mas principalmente, pelos ensinamentos sobre a vida. Mnito obrigada por toda sua ajuda, pelo incentivo e por vibrar com minhas conquistas. Wocê é um grande exemplo de ser humano, professove orientador. 
Dear Leff,

The supenvison became a greal dear friend. I am such a lucky person for having met you and having you as a mentow not only to help me with my research but abo in my life. Thants you so much for hosting me in your country. Ny stay in Canada would never be so pleasant if $\mathscr{I}$ did not have the Coils around. It makes me very happy to know $\mathscr{I}$ made friends for my life. 
ADeus,

Agradesco por minha vida ser abençoada com saúde, oportunidades e acimar de tudo, com as pessoas cestas. 
Á Faculdade de Odontologia da Universidade de Säo Paulo, que foi minha casa durante meus cursos de pós-graduaçäo.

A' Faculdade de Odontologia da University of B̈rilish Cohumbia que me acolhew e me possibilitow a desemodvimento da parte experimental deste tuabatho.

So Dr. Markus Maapasalo, chefe do departamento Oral Biological and Medical Siences e chefo da disciplina de Endodontia por permitir que, durante minhar estadia na University of BBitish Codumbia, en pasticipasse de vaisias atividades da disciplina. Fo uma experiência ensiquecedora que von vecondar por loda a minha vida.

Aos colegas Allexandev Rosencyweige Wei Wong que me ajudaram com a análise das eletromicrografias.

Ao técnico de labonatório Andre Wong pela simpatia e pelo auxilio com o microscóprio eletionnico de vanedura.

Ä Capes e ao CONPY pelo suporte financeiro dusante mew curso de doutorado.

Alos funcionánios de ambas universidades que contribuiram de alguma forma para o desenvobimento deste habalho: Ana

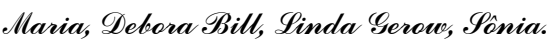

A' Gan, por ter me acollido em sua casa me fayendo sentir como em minha próferia casa, por ter sempre me estimulado a seguir men caminho e a aproveilar a vida!'

Agradeço a lodas as pessoas que, mesmo não ciladas aqui, contribuiram para a elaboraçäo e conchusão deste trabalho. Ulma palawer de afoio, um pequeno incentivo muilas vezes valem mais do que se imagina. 
Aos mens colegas de turma:

Adriana, Alexandre, Carmo, Cristiane, Denise e Sueli,

F̂i uma consivêencia muilo boa e um frivilégio poder compartilhar e aprender com vocês.

BBow Sorte a lodos no caminho... 
Denise (amigarguerida)

Nossos caminhos se conzaram nesta vida acadêmica for duas vezes: no mestrado e no doulorado. Que sorte ar minha!' Wocê é uma amiga muito especial não só pasar mim, mas para muila gente. É muito bom saber que posso sempre conlas com você. Obrigada pelas palaveras de apoio, pela confiança depositada em mime pela amizade que canneganemos pela vida loda. 
Mello I. Metodologia de avaliação da permeabilidade dentinária utilizando corante e da remoção do magma dentinário através de MEV no mesmo espécime radicular [Tese de Doutorado]. São Paulo: Faculdade de Odontologia da USP; 2008.

\section{RESUMO}

A qualidade final do preparo do canal destaca-se, dentre outras condições, pela ausência de magma dentinário e pelo aumento da permeabilidade dentinária, de modo a permitir pela primeira, a falta de substrato para desenvolvimento de microbiota e melhor adaptação do material obturador e, pelo segundo a possibilidade de alcançar na maior profundidade do túbulo dentinário as sujidades ali eventualmente presentes e fazer com que a medicação intracanal atue plenamente no sistema endodôntico. Metodologias experimentais de avaliação dessas qualidades aferem isoladamente cada uma delas dificultando a percepção de que a interação de ambas poderia permitir compreender o seu real papel no êxito da terapia endodôntica. O objetivo deste estudo consistiu-se em criar um procedimento capaz de, no mesmo espécime dental, avaliar a presença de magma e o quanto de permeabilidade dentinária radicular se alcança após o preparo químico-cirúrgico e a irrigação-aspiração final com diferentes irrigantes. Quarenta dentes unirradiculares humanos foram preparados com instrumentos rotatórios e Endo-PTC $+\mathrm{NaOCl}$ a $1 \%$ e divididos em quatro grupos $(n=10)$ no momento da irrigação-aspiração final de acordo com o irrigante a ser empregado: G I (controle) - NaOCl a 1\%; G II - EDTA a 17\%; G III - EDTA-T a 17\% e G IV - MTAD ${ }^{\circledR}$. Os canais foram preenchidos com azul de metileno a $0,5 \%$ e mantidos em frascos por $48 \mathrm{~h}$. Decorrido este tempo, as coroas foram removidas e as raízes foram clivadas no sentido transversal obtendose fragmentos do terço cervical, médio e apical. Os espécimes foram fotografados e analisados no programa ImageLab quanto à penetração do corante. Após esta 
análise, os fragmentos foram novamente clivados no sentido longitudinal e preparados para MEV. As eletromicrografias foram analisadas por três diferentes avaliadores e qualificadas por escores. As substâncias irrigadoras utilizadas, quando comparadas entre si, tiveram efeitos semelhantes sobre a permeabilidade dentinária, considerando as raízes por inteiras e pelos seus terços. Na avaliação individual das substâncias irrigadoras, as diferenças de permeabilidade entre os terços radiculares não foram estatisticamente significantes, exceto para o EDTA-T cujo terço apical teve menor penetração do corante. Quando a substância irrigadora com ação quelante/desmineralizante foi empregada para irrigação-aspiração final do canal radicular, o magma dentinário foi eficientemente removido enquanto a irrigação somente com $\mathrm{NaOCl}$ não foi suficiente para remover o magma. Os três terços do canal radicular apresentaram o mesmo grau de limpeza das paredes da dentina radicular, exceto para o EDTA-T, cujo terço apical apresentou maior quantidade de magma quando comparado aos terços cervical e médio. A vinculação dos resultados estatísticos da permeabilidade dentinária com a remoção do magma dentinário não mostrou a mesma relação uniforme para as substâncias irrigadoras avaliadas, quer na sua totalidade quer nos seus terços, deduzindo-se que maior ou menor permeabilidade necessariamente não corresponde a menor ou maior presença de magma dentinário. As análises da permeabilidade dentinária e da remoção do magma dentinário, com aplicação inicial do corante seguido de processamento para MEV, mostraram-se viáveis nos mesmos espécimes radiculares.

Palavras-Chave: corante; magma dentinário; microscopia eletrônica de varredura; permeabilidade dentinária; soluções irrigantes 
Mello I. Methodology of evaluation of dentin permeability using dye and smear layer removal using SEM in the same specimen [Tese de Doutorado]. São Paulo: Faculdade de Odontologia da USP; 2008.

\section{ABSTRACT}

After root canal preparation and removal of smear layer, penetration of intracanal dressing deep in dentinal tubules to reduce microbial growth is enhanced. Removal of smear layer also permits a more effective cleaning of organic tissue and bacteria from within the dentinal tubules and allows a better adaptation of obturation material along root canal walls. Other studies have evaluated smear layer removal and dentinal permeability in isolation on different specimens, making it difficult to interpret the interaction between smear layer and dentin permeability and their real roles in root canal treatment. The aim of this study was to create a procedure to evaluate the presence of smear layer and what its influence is on root dentin permeability after chemomechanical root canal preparation and final irrigation-aspiration with different chemicals using the same specimen. Forty single root human teeth were instrumented with rotary instruments and Endo-PTC $+1 \% \mathrm{NaOCl}$ and ramdomly divided into four groups $(n=10)$ at the final rinse step, according to the irrigant used: G I (control) - 1\% NaOCl; G II - 17\% EDTA; G III - 17\% EDTA-T and G IV - MTAD ${ }^{\circledR}$. The root canals were filled with $0.5 \%$ methylene blue and maintained in bottles for 48 h. After this time, the crowns were cut off and the roots were transversally split resulting in three fragments: coronal, middle and apical. The specimens were analyzed using ImageLab software to evaluate dye penetration. After this analysis, the fragments were then axially split and prepared for SEM. The photomicrographs were analyzed by three different evaluators and qualified by scores. When the whole 
roots were analyzed and the irrigants used were compared among themselves, the same effect on dentin permeability was observed. Individual evaluation of the irrigants showed, the differences in the permeability levels for all 3 root canal thirds were not statistically significant, except for the apical third of the EDTA-T irrigation group which exhibited less dye penetration. When a decalcifying irrigant was used for final rinse, the smear layer was efficiently removed. In contrast a final rinse with $\mathrm{NaOCl}$ was not enough to remove this layer. In all irrigation experimental groups the three different thirds of the root canals showed the same amount of smear layer removal, except for the EDTA-T group, which exhibited higher amounts of smear layer removal in the apical third compared to coronal and middle thirds. The results of both studies (dentin permeability and smear layer removal) did not show an even relationship for the irrigants evaluated, neither on their smear layer in the entire canal nor was it observed in each root canal thirds evaluated. This inferres that higher or lower dentinal permeability does not necessarily correspond to a higher or lower amount of smear layer presence. The Pearson correlation test supports these statements. The analysis of dentin permeability with initial introduction of a dye followed by the smear layer removal analysis under SEM, was shown to be a feasible procedure using the same root specimen.

Keywords: dye; smear layer; scanning electron microcopy; dentin permeability; irrigants 


\section{LISTA DE FIGURAS}

Figura 4.1 - Espécime em posição vertical no frasco preenchido com solução salina.

Figura 4.2 - Espécime após confecção dos sulcos longitudinais e transversais .65

Figura 4.3 - Fragmentos obtidos após a clivagem transversal segundo os terços radiculares (da esquerda para a direita: $\mathrm{C}=$ cervical; $\mathrm{M}=$ médio; $\mathrm{A}=$ apical)

Figura 4.4 - Processamento da imagem no programa ImageLab.

Figura 5.1 - Terços cervicais dos espécimes dos grupos submetidos ao estudo da permeabilidade dentinária - I (NaOCl); II (EDTA); III (EDTA-T); e, IV $\left(M T A D^{\circledR}\right)$. Observa-se que em todos os espécimes houve grande penetração do corante na dentina com maior concentração em torno da luz do canal. Nota-se que no espécime do grupo II a imagem sugere presença de dentina esclerótica ou atubular (seta). Verifica-se em todos os grupos o adequado isolamento do cemento radicular propiciado pelo cianoacrilato de etila, impedindo a contaminação eventual do corante no sentido cemento-canal.

Figura 5.2 - Terços médios dos espécimes dos grupos submetidos ao estudo da permeabilidade dentinária - I (NaOCl); II (EDTA); III (EDTA-T); e, IV $\left(M T A D^{\circledR}\right)$. Observa-se que em todos os espécimes houve grande penetração do corante na dentina com maior concentração em torno da luz do canal. Verifica-se em todos os grupos o adequado isolamento do cemento radicular propiciado pelo cianoacrilato de etila, impedindo a contaminação eventual do corante no sentido cemento-canal.

Figura 5.3 - Terços apicais dos espécimes dos grupos submetidos ao estudo da permeabilidade dentinária - I (NaOCl); II (EDTA); III (EDTA-T); e, IV $\left(M T A D^{\circledR}\right)$. Observa-se que em todos os espécimes houve maior penetração do corante em torno da luz do canal. Nota-se nos espécimes dos grupos II, III e IV que não houve penetração do corante em algumas áreas centrais, sugerindo-se presença de dentina esclerótica ou atubular (setas). Verifica-se em todos os grupos o adequado isolamento do cemento radicular propiciado pelo cianoacrilato de etila, impedindo a contaminação eventual do corante no sentido cementocanal. 
Figura 5.4 - Eletromicrografias dos terços cervicais dos espécimes dos grupos submetidos ao estudo da remoção do magma dentinário - I ( $\mathrm{NaOCl})$ parede totalmente coberta por magma dentinário; II (EDTA) parede livre de magma dentinário e imagem sugestiva de presença de tampões de dentina (smear plug) no interior dos túbulos dentinários; III (EDTA-T) e IV $\left(\right.$ MTAD $\left.^{\circledR}\right)$ paredes livres de magma dentinário e túbulos dentinários desobstruídos.

Figura 5.5 - Eletromicrografias dos terços médios dos espécimes dos grupos submetidos ao estudo da remoção do magma dentinário - I ( $\mathrm{NaOCl})$ parede totalmente coberta por magma dentinário; II (EDTA), III (EDTA-T) e IV $\left(M_{T A D}{ }^{\circledR}\right)$ paredes livres de magma dentinário e imagens sugestivas de presença de tampões de dentina (smear plug) no interior dos túbulos dentinários.

Figura 5.6 - Eletromicrografias dos terços apicais dos espécimes dos grupos submetidos ao estudo da remoção do magma dentinário - I ( $\mathrm{NaOCl})$ parede totalmente coberta por magma dentinário; II (EDTA), III (EDTA-T) e IV $\left(\right.$ MTAD $\left.^{\circledR}\right)$ paredes livres de magma dentinário e imagens sugestivas de presença de tampões de dentina (smear plug) no interior dos túbulos dentinários.

Figura 5.7 - Conversão dos dos resultados de permeabilidade dentinária $(\bullet)$ e remoção de magma dentinário $(\downarrow)$ em porcentagens de ocorrência e sua correspondente relação segundo os terços radiculares em cada grupo experimental.

Figura 5.8 - Coeficiente de correlação de Pearson para os grupos testados segundo as médias de permeabilidade dentinária e de magma dentinário 90

Figura 5.9 - Coeficiente de correlação de Pearson para os terços radiculares dos grupos testados segundo as médias de permeabilidade dentinária e de magma dentinário. 


\section{LISTA DE TABELAS}

Tabela 5.1 - Média (em porcentagem) da penetração do corante nos grupos avaliados e nos diferentes terços do canal radicular com os respectivos desvios padrão e níveis de significância de $5 \%$ entre si.

Tabela 5.2 - Valores absolutos das diferenças entre as médias dos tratamentos segundo os terços radiculares e teste de Tukey ${ }_{5 \%}$

Tabela 5.3 - Médias dos escores de remoção do magma dentinário nos grupos avaliados e nos diferentes terços do canal radicular e níveis de significância de $5 \%$ entre si.

Tabela 5.4 - Valores absolutos das diferenças entre os postos médios dos tratamentos de acordo com os terços radiculares e níveis de significância estatística de Kruskal-Wallis segundo o método de Dunn

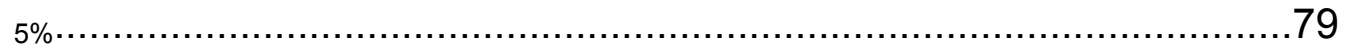

Tabela 5.5 - Comparações dos níveis de significância estatística entre os testes da permeabilidade dentinária e da remoção do magma dentinário para os grupos avaliados.

Tabela 5.6 - Comparações dos níveis de significância estatística entre os testes da permeabilidade dentinária e da remoção do magma dentinário para os terços de cada substância avaliada.

Tabela 5.7 - Comparações dos níveis de significância estatística entre os testes da permeabilidade dentinária e da remoção do magma dentinário das substâncias avaliadas em cada terço.

Tabela 5.8 - Correlação entre a infiltração e magma dentinário com nível de significância de $\alpha=0,05$. 


\section{LISTA DE ABREVIATURAS, SIGLAS E SÍMBOLOS}

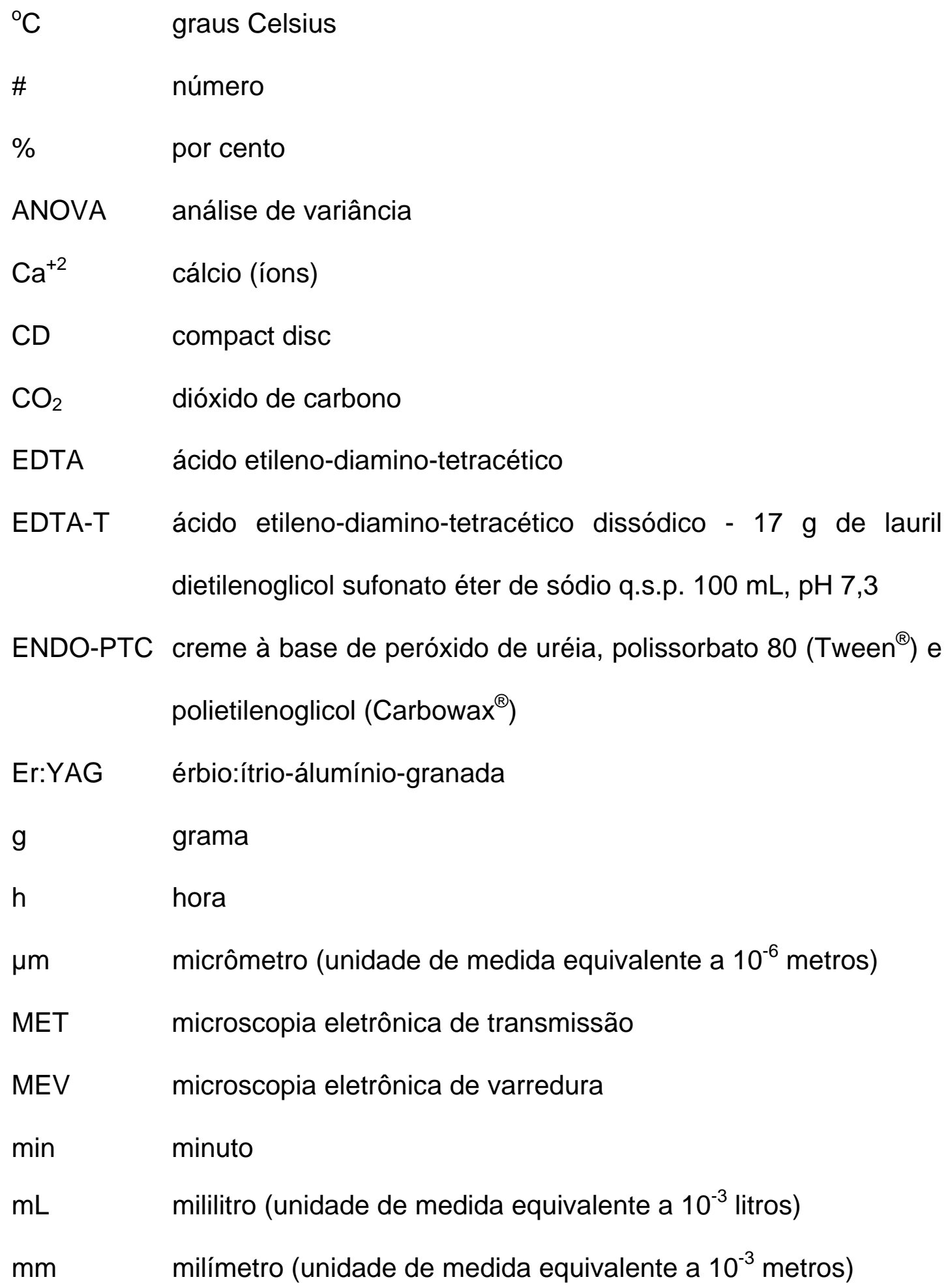


MTAD solução de ácido cítrico a 4,25\%, solução aquosa de doxiciclina a 3\% e polissorbato $80\left(\right.$ Tween $\left.^{\circledR}\right)$ a 0,5\% - $\left(\right.$ Biopure MTAD ${ }^{\circledR}$ ) $\mathrm{NaOCl}$ hipoclorito de sódio NDP medicação intracanal à base de paramonoclorofenol, fosfato de dexametasona veiculada em polietilenoglicol e rinossoro PBS Solução salina fosfato-tamponada

$\mathrm{pH} \quad$ potencial hidrogeniônico

PQC preparo químico-cirúrgico 


\section{SUMÁRIO}

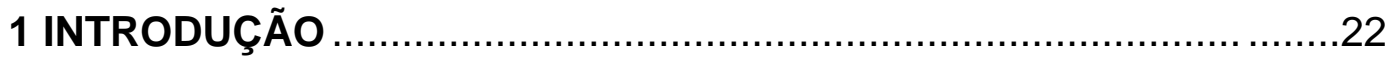

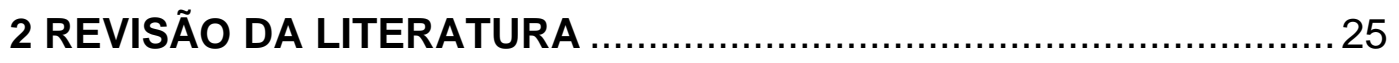

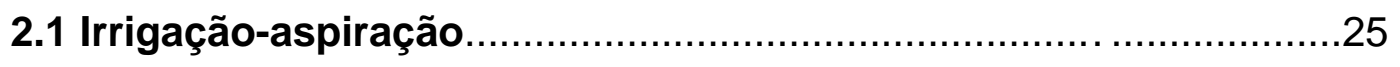

2.1.1 A importância da irrigação-aspiração para o sucesso da terapia

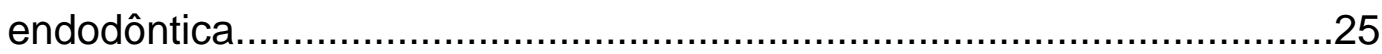

2.1.2 As substâncias irrigadoras..............................................26

2.2 A permeabilidade dentinária ............................................28

2.2.1 Definição e importância da permeabilidade dentinária dentro da

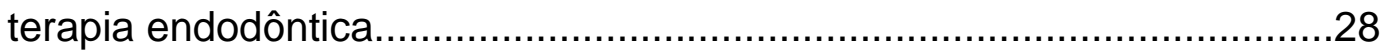

2.2.2 Os estudos sobre permeabilidade dentinária.............................32

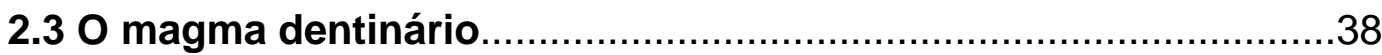

2.3.1 Definição e importância do magma dentinário dentro da terapia

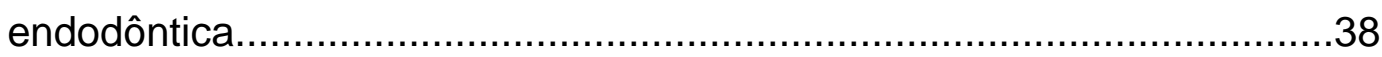

2.3.2 Os estudos sobre magma dentinário.......................................40

2.4 Estudos sobre permeabilidade dentinária x remoção do magma

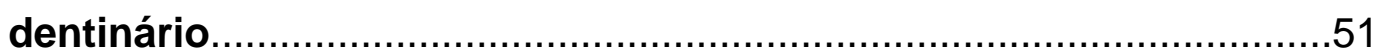

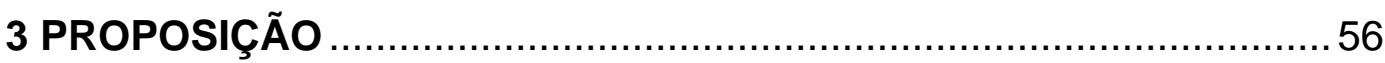

4 MATERIAL E MÉTODOS ..................................................... 57

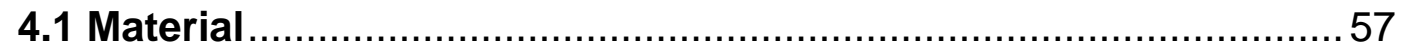

4.2 Métodos........................................................................ 60

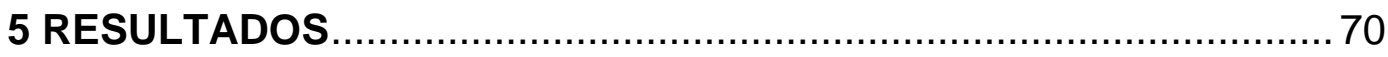

5.1 Estudo da permeabilidade dentinária....................................70 
5.3 Inter-relações dos estudos da permeabilidade dentinária e da remoção do magma dentinário..............................................83

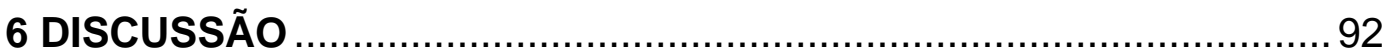

6.1 Estudo da permeabilidade dentinária....................................... 95

6.2 Estudo da remoção do magma dentinário................................ 100

6.3 Inter-relação entre permeabilidade dentinária e remoção do

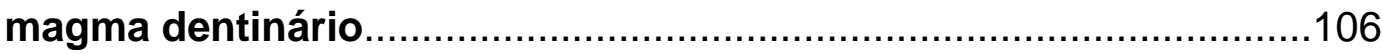

6.4 Considerações finais..........................................................112

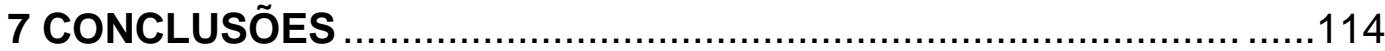

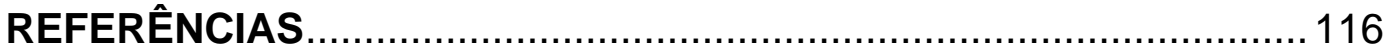

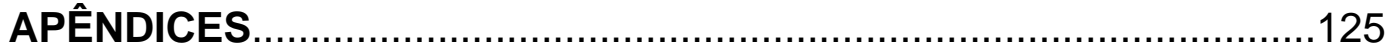

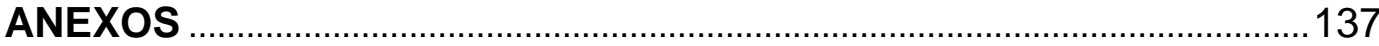




\section{INTRODUÇÃO}

O objetivo principal do tratamento endodôntico é promover a limpeza e desinfecção do sistema de canais radiculares para restabelecer a cura e devolver o dente às suas funções. É durante a fase de preparo químico-cirúrgico que a ação conjunta dos instrumentos e substâncias irrigadoras promovem uma série de alterações estruturais na dentina preparando-a para receber a obturação.

O tecido dentinário possui uma característica natural, a permeabilidade, que permite que fluidos transitem por sua matriz, principalmente através dos túbulos dentinários, que atuam como vias de transporte. É por meio destes que as substâncias irrigadoras e a medicação intracanal alcançam as regiões mais profundas da dentina até o cemento. A utilização de determinadas substâncias irrigadoras aumenta a permeabilidade natural da dentina, facilitando a entrada e penetração de irrigantes e drogas.

A ação dos instrumentos sobre a dentina cria uma camada que se deposita na superfície das paredes do canal. Esta camada, denominada magma dentinário, é composta de matérias orgânica e, principalmente, inorgânica e age como uma barreira física, que possivelmente dificulta a atuação das substâncias irrigadoras, da medicação intracanal e também impede o íntimo contato do material obturador com as paredes do canal. O magma dentinário ainda pode conter ou ser invadido por microorganismos e também oferecer proteção a biofilmes aderidos às paredes do canal radicular. Tais fatos podem contribuir para o insucesso do tratamento endodôntico, já que a presença de 
microorganismos e de sujidade pode desencadear inflamação no periodonto apical e conseqüente desenvolvimento de rarefações ósseas.

A seleção das substâncias irrigadoras empregadas durante o tratamento endodôntico recai sobre uma série de propriedades, dentre elas: não ser citotóxica, ser bactericida, ser solvente de matéria orgânica, impedir ou remover o magma dentinário e ser tensoativo superficial e interfacial. $\mathrm{Na}$ atualidade, não existe uma substância irrigadora ideal que apresente todos os pré-requisitos desejáveis para uma solução a ser empregada durante a fase do preparo do canal.

Dentre as substâncias irrigadoras disponíveis, o hipoclorito de sódio é que apresenta maior número de requisitos necessários por possuir a característica única de dissolução tecidual além de ser antimicrobiana e apresentar relativa tolerância tecidual desde que em baixas concentrações, sendo mundialmente o irrigante de escolha para o preparo químico-cirúrgico.

Para finalizar o preparo do canal, o magma dentinário deve ser removido. Como o hipoclorito de sódio não atua em matéria inorgânica, faz-se necessária a complementação da irrigação final com um agente capaz de atuar nos íons cálcio da dentina para remover a porção inorgânica do magma dentinário.

Os ácido fracos, tais como o EDTA e o ácido cítrico, empregados com esta finalidade, obtém sucesso há vários anos. A associação de tensoativos e antibacterianos a estes ácidos é indicada para melhorar ou complementar suas propriedades. Nesta linha de raciocínio, foi adicionado um detergente aniônico (Tergentol $^{\circledR}$ ) ao EDTA para dar-Ihe tensoatividade e facilitar o contato do quelante com a superfície dentinária. $O M T A D^{\circledR}$ é a associação de solução aquosa de doxiciclina a 3\% (antibiótico), ácido cítrico a 4,25\% e polissorbato 80 (detergente). O objetivo desta 
formulação é associar o poder desmineralizante do ácido cítrico ao poder antibacteriano do antibiótico de largo espectro e à tensoatividade do detergente.

A maioria dos estudos endodônticos atuais relaciona 0 aumento da permeabilidade da dentina à eliminação do magma dentinário empregando agentes indicadores e microscopia eletrônica de varredura. Diversas pesquisas já foram desenvolvidas no intuito de identificar ou estabelecer seus papéis no tratamento endodôntico tendo em conta que o magma dentinário pode interferir na permeabilidade da dentina, sem ter sido esta relação, cabalmente comprovada.

A literatura existente não elucida tais questões, sendo que dificuldades metodológicas inviabilizavam a compreensão do papel exato do magma dentinário sobre a permeabilidade da dentina. Portanto, é desejável que se realize uma incursão científica nos recursos metodológicos usualmente utilizados na avaliação da permeabilidade e na remoção do magma dentinário, de modo a relacionar os resultados obtidos e verificar a correlação entre os mesmos. 


\section{REVISÃO DA LITERATURA}

\subsection{Irrigação-aspiração}

2.1.1 A importância da irrigação-aspiração para o sucesso da terapia endodôntica

A terapia endodôntica tem como finalidade modelar e sanificar o sistema de canais radiculares para receber a obturação endodôntica a fim de que o dente possa retornar às suas funções normais. Durante a fase do PQC, a ação conjunta dos instrumentos e substâncias químicas provoca alterações tanto anatômicas quanto estruturais na dentina. As substâncias irrigadoras atuam quimicamente alterando a permeabilidade e desinfetando o sistema endodôntico. Já os instrumentos, excisam a dentina através da ação mecânica, modelando o canal principal (HAAPASALO et al., 2005).

Ao término do preparo do canal, restos de tecido orgânico e inorgânico que são depositados sobre as paredes do canal radicular devem ser removidos. A fase de irrigação-aspiração tem como objetivo fazer a toalete final da cavidade, deixandoa propícia para receber a obturação endodôntica. Esta condição pode ser obtida lavando-se o canal principal com substâncias irrigadoras depositadas com o auxílio de agulhas de fino calibre e aspiração concomintante para eliminar os produtos em suspensão (PAIVA; ANTONIAZZI, 1993; LAGE-MARQUES; ANTONIAZZI, 2002; UNIVERSIDADE DE SÃO PAULO, 2004). 


\subsubsection{As substâncias irrigadoras}

O $\mathrm{NaOCl}$ é a solução irrigadora mais utilizada no preparo do canal radicular por possuir o maior número de requisitos para um irrigante endodôntico, tais como: efeito antimicrobiano, dissolução tecidual e biocompatibilidade satisfatória em baixas concentrações (PAIVA; ANTONIAZZI, 1993; SPANÓ et al., 2001; ESTRELA et al., 2002; HAAPASALO et al., 2005; ZEHNDER, 2006; UNIVERSIDADE DE SÃO PAULO, 2004).

Nygaard-Østby (1957) preconizou o EDTA como solução auxiliar no preparo de canais radiculares, pois por meio da sua ação quelante, permite formular uma solução auxiliar para a instrumentação principalmente de canais atrésicos. Por ser biologicamente compatível com os tecidos, o autor preconiza o seu emprego em substituição aos ácidos inorgânicos até então utilizados. Essa solução aquosa de EDTA somada ao hidróxido de sódio, tem uma composição final de 15\% de EDTA e $\mathrm{pH}=7,3$. O EDTA também é empregado na irrigação final do canal radicular para remoção do magma dentinário (HULLSMANN; HECKENDORFF; LENNON, 2003). A irrigação com EDTA possivelmente facilita o desprendimento de biofilmes aderidos às paredes do canal radicular (ZEHNDER, 2006). Tal fato explica porque a irrigação com o EDTA provou ser superior ao soro fisiológico quando da redução da microbiota intracanal, apesar do fato de possuir capacidade antisséptica relativamente limitada (YOSHIDA et al., 1995).

Paiva e Antoniazzi (1993) sugeriram o acréscimo de 1,25\% de lauril-dietilenoéter-sulfato de sódio à fórmula original do EDTA objetivando melhorar o poder umectante da solução e empregá-la com a finalidade de remover a camada residual 
de magma após o preparo do canal. O detergente auxilia no processo de limpeza, diminuindo a tensão superficial, permitindo que a solução entre em contato mais rapidamente com as paredes do canal. O arranjo característico da molécula detergente lhe confere propriedades umectante e emulsionante, de modo que a contaminação gordurosa do canal é absorvida e mantida em suspensão (PAIVA, ANTONIAZZI, 1973).

Mais recentemente, Torabinejad et al. (2003b) idealizaram o MTAD ${ }^{\circledR}$ (mistura de tetraciclina, ácido e detergente) também para irrigação final do canal radicular combinando solução aquosa de doxiciclina a 3\% (antibiótico), ácido cítrico a 4,25\% e polissorbato 80 a $0,5 \%$ (detergente). Este produto, segundo os autores, além de remover o magma dentinário por meio da ação desmineralizante do ácido cítrico e também da ação quelante da doxiciclina, tem poder umectante e age nos microorganismos que resistiram ao preparo do canal. A combinação do $\mathrm{NaOCl}$ a 1,3\% como substância irrigadora auxiliar do $P Q C$ e MTAD $^{\circledR}$ como irrigante final mostrou-se mais efetiva contra Enterococcus faecalis do que quando o EDTA foi aplicado seguido de nova irrigação com $\mathrm{NaOCl}$ a 1,3 ou 5,25\% (SHABAHANG; TORABINEJAD, 2003). Portenier et al. (2006) também verificaram que o MTAD ${ }^{\circledR}$ é eficaz sobre E. faecalis, mesmo na presença de albumina, aproximando o estudo de uma situação in vivo. Krause, Liewehr e Hahn (2007) utilizando dentes bovinos também contaminados com $E$. faecalis obtiveram níveis melhores de descontaminação com $\mathrm{NaOCl}$ a $5,25 \%$ e doxiciclina $100 \mathrm{mg} / \mathrm{mL}$ do que com $\mathrm{MTAD}^{\circledR}$ ou ácido cítrico. Rossi-Fedele e Roberts (2007) compararam a capacidade do E. faecalis de sobreviver à irrigação com solução contendo tetraciclina em dentes bovinos e verificaram que houve resistência do microorganismos ao antibiótico. Os resultados referentes aos danos causados ao tecido dentinário são controversos, 
sendo que alguns mostram grande extensão de desmineralização, enquanto outros não (GARCÍA-GODOY et al., 2005; MACHNICK et al., 2003).

Outras substâncias irrigadoras podem ser empregadas durante o tratamento endodôntico, no entanto, aqui somente foram abordadas aquelas utilizadas neste estudo.

\subsection{A permeabilidade dentinária}

2.2.1 Definição e importância da permeabilidade dentinária dentro da terapia endodôntica

Anteriormente à abordagem do tema permeabilidade, é importante compreender o tecido dentinário e seus componentes. O sistema de canais radiculares é representado não só pelo canal principal, mas também por um complexo sistema de canais secundários, laterais, acessórios, delta apical e túbulos dentinários. Do ponto de vista estrutural, a dentina constitui-se de um tecido calcificado apresentando em sua extensão, túbulos dentinários que variam aproximadamente de 30.000 a $70.000 / \mathrm{mm}^{2}$ com diminuição gradual do diâmetro do centro para a periferia, em torno de 5 e $1 \mu \mathrm{m}$, respectivamente. No que diz respeito à quantidade, existe maior número de túbulos no terço cervical da raiz, diminuindo gradativamente até o terço apical (SELTZER; BENDER, 1975).

A dentina é um tecido conjuntivo mineralizado, constituído basicamente por 
cerca de 50 a $70 \%$ de material inorgânico, 18 a 30\% de material orgânico e 12 a 20\% de água (RODE; PENNA; CAVALCANTI, 2000).

Whittaker e Kneale (1979) examinaram número de túbulos dentinários da coroa ao ápice dos dentes utilizando MEV. As eletromicrografias revelaram que o número de túbulos dentinários é maior na região coronária, e a projeção ao longo dos canais radiculares evidenciou que dessa área, em direção ao ápice, o número de túbulos vai diminuindo, principalmente na área apical.

Alguns fatores afetam diretamente a permeabilidade dentinária, tais como: diâmetro do canal, idade do paciente, integridade do dente, natureza da substância química e o magma dentinário formado durante o preparo químico cirúrgico. $\mathrm{O}$ magma pode obstruir a entrada dos túbulos dentinários diminuindo a permeabilidade dentinária em até $49 \%$, interferindo, dessa forma, na ação de substâncias químicas irrigantes e na medicação intracanal (DIPPEL; BORGGREVEN; HOPPENBROUWERS, 1984).

Estudando a permeabilidade dentinária, Pashley (1984) afirmou que a maior via de acesso para a difusão de soluções na dentina seria pelos túbulos dentinários e ressaltou que a dentina sem túbulos era mais impermeável. O autor citou, também, os fatores físicos importantes que interferem na permeabilidade dentinária, tais como: superfície de área difusional (produto do número de túbulos pela área de sua luz), espessura da dentina, temperatura da dentina e espécie do agente que se difunde através desse tecido. Os túbulos dentinários, no seu estado normal, são túneis longos e fechados em sua parte periférica pelo esmalte ou cemento. Eles são cheios de fluido de composição similar aos fluidos extra celulares.

Pashley e Livingston (1978) verificaram que o tamanho da molécula de substâncias a serem difundidas na dentina influencia a permeabilidade dentinária. 
As substâncias com tamanho molecular menor permeam a dentina mais facilmente, inclusive na presença de barreira física, como o magma dentinário. Quanto maior o tamanho molecular, mais restrita será a penetração da substância. Quando o magma dentinário foi removido, o trânsito das substâncias com maior tamanho molecular foi facilitado.

No mesmo ano, Pashley, Livingston e Greenhill (1978) analisaram os fatores que influenciam na resistência ao fluxo de líqüidos através da dentina coronária, observando os seguintes aspectos: 1 - resistência de superfície devido à presença de débris que podem ocluir os túbulos dentinários; 2 - resistência intratubular devido à mineralização e irregularidades no interior dos túbulos; 3 - resistência pulpar devido à presença dos prolongamentos odontoblásticos e corpos celulares no interior dos túbulos. Com base nos resultados obtidos, os autores observaram que a magnitude de resistência ao fluxo de líquidos através da dentina é dependente da presença ou ausência do tecido pulpar, da presença ou ausência de debris na superfície dos túbulos e, também, do grau de oclusão dos túbulos.

Pashley et al. (1978) também analisaram os efeitos das alterações na superfície dentinária (após polimento versus após ataque ácido) utilizando-se de dois agentes traçadores com tamanhos moleculares diferentes $\left({ }^{3} \mathrm{H}_{2} \mathrm{O}\right.$ - água deuterada versus albumina) para verificar alterações na permeabilidade dentinária. Após condicionamento ácido da dentina a permeabilidade foi aumentada.

Mjör (1985) cita um grande número de fatores que podem afetar a penetração de substâncias ou fluidos através de um tecido, como por exemplo: tensão superficial, forças capilares, carga elétrica e tamanho molecular. A permeabilidade é considerada como sendo a expressão da soma de todos os processos que atuam na passagem de substâncias e fluidos através do tecido. A permeabilidade dentinária é 
também afetada marcadamente pelo grau de obliteração dos túbulos, e estes são o principal caminho através deste tecido. A quebra na continuidade desses túbulos será efetiva na redução da permeabilidade dentinária. Os túbulos podem terminar totalmente obliterados ou somente em uma pequena parte de seu trajeto.

Dippel, Borggreven e Hoppenbrouwers (1984) teceram comentários sobre o transporte de substâncias através da dentina, afirmando que a principal via são os túbulos dentinários e que este transporte pode ser diminuído em até 35\% quando os orifícios de entrada dos túbulos dentinários são cobertos por debris após o corte da dentina. Não somente a cobertura das paredes do canal por debris mas principalmente a obstrução dos túbulos dentinários servirá como barreira a fluidos. Tal fato é de alta relevância para o tratamento endodôntico pois tanto as substâncias irrigadoras quanto a medicação intracanal empregada entre sessões devem penetrar na dentina para agir em profundidade.

Harrán Ponce, Canalda Sahli e Vilar Fernandez (2001) estudaram a arquitetura dos túbulos dentinários de molares superiores humanos em detalhes, utilizando MEV. Verificaram que a densidade numérica dos túbulos dentinários é maior no terço cervical da raiz. A porcentagem de área ocupada pelos túbulos dentinários por $\mathrm{mm}^{2}$ de dentina foi significantemente maior na superfície interna quanto comparada à superfície externa. A forma da abertura dos túbulos dentinários foi mais circular na dentina coronária e irregular à medida que se aproximava do terço apical da raiz. Os autores também comentaram neste trabalho que os túbulos são os meios pelos quais a polpa e os tecidos mineralizados se comunicam e que é através dos túbulos que diversos agentes podem causar danos tanto à polpa quanto ao ligamento periodontal. 
Mesmo com um PQC criterioso, pequenas irregularidades podem abrigar microorganismos. O aumento da permeabilidade natural da dentina durante o PQC é extremamente importante para que os irrigantes e também a medicação intracanal possam ser efetivas em áreas inacessíveis à instrumentação (BAKER et al., 1975; GOLDBERG; ABRAMOVICH, 1977; RALDI; LAGE-MARQUES, 2003).

2.2.2 Os estudos sobre permeabilidade dentinária

Fish (1933) foi um dos pioneiros a estudar a permeabilidade dentinária com o uso de corantes e descreveu o perfil da penetração do azul de metileno, que se faz no sentido da câmara para as junções dentina-esmalte e dentina-cemento. Porém, nos casos em que existia hipercalcificação, a dentina tornou-se praticamente impermeável.

Marshall, Massler e Dute (1960) analisaram a variação da permeabilidade dentinária aos isótopos $\mathrm{P}^{32}, \mathrm{Na}^{22}, \mathrm{I}^{131}$ e $\mathrm{S}^{35}$ em raízes de dentes recém-extraídos, após o uso de vários medicamentos. A penetração dos radioisótopos era avaliada por autogramas e o índice da permeabilidade dentinária era computado para cada espécime, nas regiões cervical, média e apical do canal, cada qual subdividida em terços laterais e longitudinais designadores da profundidade e extensão, resultando para cada região um quadriculado composto de nove elementos. A região apical apresentou-se praticamente impermeável aos isótopos, ao contrário das regiões cervical e média. Quanto aos medicamentos, o $\mathrm{NaOCl}$ e a solução de peróxido de 
hidrogênio aumentaram a permeabilidade dentinária enquanto o EDTA e o bicarbonato de sódio promoveram sua diminuição.

Robazza (1973) verificou as variações da permeabilidade da dentina radicular em dentes humanos variando a substância química auxiliar da instrumentação da seguinte maneira: grupo I - água oxigenada e soda clorada durante a instrumentação e irrigação-aspiração segundo Grossman; grupo II - associação detergente - Furacin durante a instrumentação e irrigação-aspiração segundo Varella e Paiva; grupo III - Endo-PTC neutralizado pelo líquido de Dakin durante a instrumentação e irrigação-aspiração com associação detergente - Furacin segundo Paiva e Antoniazzi e grupo IV - água destilada durante a instrumentação e para irrigação-aspiração. O autor concluiu que a associação Endo-PTC neutralizado pelo líquido de Dakin foi a que apresentou maior homogeneidade quanto à penetração do corante e também foi a que mais aumentou a permeabilidade do terço apical. De todas as regiões do canal radicular, a apical foi a que apresentou menor permeabilidade.

Goldman et al. (1976) avaliaram a influência de dois tipos de agulha de irrigação sobre a qualidade da limpeza do canal radicular. Uma delas, preconizada pelos autores, apresentava perfurações laterais e a outra era do tipo convencional, com saída em direção apical. Quanto à efetividade da limpeza, aquela preconizada pelos autores ofereceu melhor resultado, já que o líquido irrigante é dirigido diretamente contra as paredes do canal e não em direção ao ápice. A pressão hidráulica é menor quando utiliza-se uma agulha perfurada lateralmente e, em conseqüência, não promove possíveis injúrias nos tecidos periapicais pelas soluções irrigantes utilizadas, principalmente em canais atresiados. Esse estudo foi realizado 
in vitro, com o uso de solução aquosa de azul de toluidina a $0,1 \%$ a fim de comprovar a infiltração no tecido dentinário. No estudo in vivo, verificaram que o uso de agulha perfurada lateralmente praticamente não incidia dores pós-operatórias e lesões no periodonto.

Fraser e Laws (1976) compararam o efeito de três diferentes preparações contendo EDTA (Decal, Largal Ultra e RC-Prep) na permeabilidade da dentina. Em todos os espécimes houve diminuição na penetração do corante quando comparados ao grupo controle, que foi lavado somente com água. Os autores também verificaram penetração quase nula do corante na região apical.

Robazza e Antoniazzi (1976) analisaram o comportamento de algumas substâncias químicas auxiliares da instrumentação frente à permeabilidade dentinária. O grupo no qual o EDTA foi utilizado durante o preparo do canal, seguido de irrigação-aspiração com lauril-dietileno-glicol-éter-sulfato-de-sódio (Tergentol ${ }^{\circledR}$ ) e o grupo no qual água oxigenda a 10 volumes foi empregada como auxiliar do preparo do canal e também na irrigação-aspiração final foram os que apresentaram menores índices de permeabilidade dentinária. O grupo no qual o Tergentol ${ }^{\circledR}$ foi usado tanto durante o preparo do canal quanto para irrigação-aspiração final foi o que apresentou maior permeabilidade dentinária radicular. A região apical foi a menos permeável, independente da substância química utilizada.

Moura (1985) analisou a porcentagem de penetração dentinária do corante azul de metileno em dentes humanos recém-extraídos. Para o PQC foram utilizadas limas tipo $\mathrm{K}$ de duas procedências e limas tipo K-Flex, levando-se em consideração o número de vezes que as mesmas foram utilizadas para o preparo do canal. $O$ creme Endo-PTC neutralizado pelo líquido de Dakin como substâncias químicas 
auxiliares. Os resultados mostraram que não houve variação estatisticamente significante na penetração do corante em função da variação do instrumento e que o aumento do número de usos diminuiu a porcentagem de penetração do corante, principalmente na região apical.

Pécora (1985) estudou a permeabilidade da dentina radicular em caninos humanos após a instrumentação manual dos canais radiculares, com o uso de diferentes soluções irrigantes: líquido de Dakin, solução de Milton, soda clorada, soda clorada alternada com água oxigenada, EDTA, ácido cítrico, RC-PREP mais soda clorada, tergentol-furacin, Endo-PTC neutralizado com líquido de Dakin e água como controle. A permeabilidade da dentina radicular foi estudada por meio de cortes transversais, com a adoção de um método histoquímico. A quantificação dos níveis de permeabilidade foi realizada com análise morfométrica. Baseando-se nos resultados, concluiu-se que as soluções halogenadas, a soda clorada alternada com água oxigenada, o EDTA e o ácido cítrico foram os irrigantes que mais aumentaram a permeabilidade da dentina radicular.

Zuolo et al. (1987) estudaram o efeito do EDTA e suas associações com tensoativos aniônicos e catiônicos, na permeabilidade da dentina radicular de incisivos superiores humanos removidos cirurgicamente. Eles utilizaram o método histoquímico para medir a permeabilidade dentinária radicular. A associação mais efetiva em promover aumento da permeabilidade foi a do EDTA-C, quando comparada ao EDTA, EDTA-T e EDTA + cetil piridino. A permeabilidade do EDTA-T foi semelhante à da solução salina.

Prokopowitsch, Moura e Muench (1989) analisaram a permeabilidade dentinária radicular do terço apical do canal, tendo como fonte de variação, a substância química auxiliar da instrumentação e irrigação final: soro fisiológico para 
instrumentação e irrigação final (controle), tergentol-furacin para instrumentação e irrigação final, $\mathrm{NaOCl}$ a $1 \%$ para instrumentação e irrigação final, Endo-PTC associado ao $\mathrm{NaOCl}$ a $1 \%$ para instrumentação e irrigação final com tergento-furacin e finalmente, EDTA-T para instrumentação e irrigação final. O creme de Endo-PTC neutralizado pelo $\mathrm{NaOCl}$ foi a associação que mais aumentou a permeabilidade dentinária. O soro fisiológico seguido do $\mathrm{NaOCl}$ a $1 \%$ foi o que menos aumentou a permeabilidade radicular e as outras substâncias utilizadas ficaram numa situação intermediária.

Grempel, Antoniazzi e Paiva (1990) estudaram a permeabilidade radicular natural em dentes extraídos de diferentes faixas etárias, sem a aplicação de drogas ou medicamentos, utilizando os corantes Rodamina B e azul de metileno. Quando a Rodamina B foi empregada, houve maior percentual de penetração em relação às regiões cervical, média e apical do que quando o corante azul de metileno foi utilizado. Independente do corante, a região apical apresentou menor infiltração. O grupo de dentes com faixa etária mais avançada apresentou menor infiltração dos corantes.

Pécora et al. (1993) estudaram o efeito das soluções de Dakin e de EDTA isoladas, alternadas e misturadas sobre a permeabilidade da dentina radicular. Os autores usaram o método histoquímico para revelar a permeabilidade dentinária e quantificaram-na por meio da análise morfométrica. Os resultados obtidos demonstraram que, tanto o uso alternado como o misturado dessas soluções promoveu maior aumento da permeabilidade em relação ao uso dessas soluções de modo isolado e que o terço apical foi menos permeável do que os terços cervical e médio. 
Fróis (1999) avaliou quantitativamente o diferencial da permeabilidade dentinária radicular do dente com polpa viva e polpa morta após a realização do preparo do canal. Os resultados mostraram que os dentes com polpa morta apresentaram maior permeabilidade quando comparados àqueles com polpa viva e que, independente da condição pulpar prévia, a permeabilidade diminui de cervical para apical.

Ribeiro (2001) comparou a permeabilidade dentinária das paredes dos canais radiculares instrumentados com diferentes soluções irrigadoras auxiliares $(\mathrm{NaOCl} a$ 1\%, lauril-dietilenoglicol-éter sulfato de sódio a $0,1 \%$, ácido cítrico a $10 \%$, EDTA a 15\% e água destilada deionizada) associados ou não à irradiação do laser Er:YAG. A água destilada deionizada associada ao laser Er:YAG e o uso isolado do $\mathrm{NaOCl}$ a $1 \%$ promoveram os maiores valores de evidenciação da permeabilidade dentinária radicular em relação aos demais tratamentos e de modo estatisticamente semelhante entre si. Os tratamentos realizados com as soluções de $\mathrm{NaOCl}$ a $1 \%$, EDTA a $15 \%$, ácido cítrico a $10 \%$ e lauril dietilenoglicol éter sulfato de sódio a $0,1 \%$ todas associadas ao uso do laser Er:YAG, e com as soluções de EDTA a 15\% e ácido cítrico a 10\%, utilizadas isoladamente apresentaram evidenciação da permeabilidade dentinária de modo estatisticamente semelhante entre si e com valores intermediários quando comparados aos demais tratamentos, ou seja, valores maiores que os obtidos com o uso da água destilada deionizada e com lauril dietilenoglicol éter sulfato de sódio a $0,1 \%$ e menores que os valores de evidenciação da permeabilidade obtidos com a utilização da água destilada deionizada associada ao laser Er:YAG e à solução de $\mathrm{NaOCl}$ a $1 \%$ utilizada isoladamente. Os terços cervical e médio dos canais radiculares apresentam valores de evidenciação da permeabilidade dentinária de modo estatisticamente 
semelhantes entre si e maiores que os valores obtidos no terço apical, em todos os tratamentos realizados.

Pascon, Kantovitz e Puppin-Rontani (2006) realizaram uma revisão da literatura sobre a influência de substâncias irrigadoras na dentina radicular de dentes decíduos e permanentes e verificaram que todas as substâncias empregadas atualmente para o preparo do canal aumentam a permeabilidade dentinária e que a combinação de irrigantes se faz necessária para otimizar este aumento.

Marending et al. (2007) desenvolveram um estudo sobre as alterações ocorridas no tecido dentinário após imersão de blocos de dentina em diferentes concentrações de soluções de $\mathrm{NaOCl}$. Uma das análises feitas foi a alteração da permeabilidade dentinária. Verificaram que a penetração do corante nos espécimes do grupo controle, que foram imersos em água, ocorreu somente através dos túbulos dentinários enquanto nos espécimes imersos em soluções de $\mathrm{NaOCl}$ a penetração do corante ocorreu também na dentina intertubular.

\subsection{0 magma dentinário}

2.3.1 Definição e importância do magma dentinário dentro da terapia endodôntica

O PQC tem por finalidade obter um canal principal modelado de forma cônica e também sanificar o sistema, limpando, desinfetando e aumentado a permeabilidade natural da dentina (PAIVA; ANTONIAZZI, 1993). 
Durante a fase de preparo do canal é formada uma camada amorfa denominada magma dentinário. Juntamente com as soluções irrigadoras, a dentina excisada forma uma massa constituída de material inorgânico (raspas de dentina, contendo hidroxiapatita) e material orgânico (células da polpa, células sangüíneas, fibras nervosas, vasos, colágeno e líquido tissular, restos necróticos, bactérias). Esta massa é denominada de magma dentinário, tendo uma espessura que varia de 1 a 5 um (PASHLEY, 1984; MADER; BAUMGARTNER; PETERS, 1984). O termo smear layer, em inglês, prevaleceu sobre qualquer tentativa de tradução por descrever de forma simples e correta a real natureza desta estrutura. Ao longo do texto, tanto o termo em português como em inglês será apresentado. Os componentes da smear layer podem penetrar no interior dos túbulos dentinários a uma distância de até 40 $\mu \mathrm{m}$, sendo chamados então de smear plug. Isto pode ocorrer como resultado do movimento linear ou de rotação dos instrumentos e também pela ação de capilaridade gerada entre os túbulos dentinários e a smear layer (CENGIZ; AKTENER; PISKIN, 1990).

Antigamente, acreditava-se que o magma dentinário poderia ser benéfico por servir como barreira à penetração de microorganismos na dentina e diminuir a permeabilidade dentinária. Entretanto, Akpata e Blechman (1982) provaram que o magma produzido pela instrumentação do canal é permeável à streptococci. Além disso, o magma dentinário pode ser lentamente dissolvido caso exposto à constante microinfiltração, criando um espaço entre a dentina e o material selador adjacente, acarretando contaminação bacteriana. O próprio magma pode alojar microorganismos e/ou seus subprodutos atuando como um reservatório para irritantes em potencial em um canal obturado (TORABINEJAD et al., 2002). 
Embora ainda haja alguma controvérsia, atualmente, a remoção do magma dentinário é altamente recomendada, já que contém microorganismos, prejudica a difusão das substâncias irrigadoras e da medicação intracanal para a periferia da dentina e impede contato íntimo do material obturador com as paredes do canal (ØRSTAVIK; HAAPASALO, 1990; CZONSTKOWSKY; WILSON; HOLSTEIN, 1990; TORABINEJAD et al., 2002; MELLO, 2006).

Algumas substâncias químicas têm sido empregadas para eliminação de tal camada. Os ácidos fracos desempenham este papel com bastante eficiência. Dentre eles, o ácido cítrico em diferentes concentrações e o EDTA puro ou associado a detergentes têm sido mais comumente empregados (PAIVA; ANTONIAZZI, 1993, SCELZA, 1998; HULSMANN; HECKENDORFF; LENNON, 2003). Porém, estes ácidos agem somente nos compontentes inorgânicos do magma, necessitando assim, associar um agente que atue na porção orgânica (LAGE-MARQUES; ANTONIAZZI, 2002). O NaOCI possui a característica única de dissolução tecidual e faz com que tecido pulpar, células e microorganismos sejam liqüefeitos, sendo passíveis de serem aspirados (PAIVA; ANTONIAZZI, 1993; SPANÓ et al., 2001; ESTRELA et al., 2002; HAAPASALO et al., 2005).

\subsubsection{Os estudos sobre magma dentinário}

McComb e Smith (1975), em um estudo pioneiro, observaram sob MEV, o efeito de diversas soluções irrigadoras utilizadas no tratamento endodôntico sobre as paredes dentinárias do canal radicular. Observou-se pela primeira vez a formação de 
uma camada amorfa aderida às paredes dos canais radiculares como resultado do preparo do canal. Estes autores, bastante surpresos com seus achados, concluíram que o EDTA associado a um detergente foi capaz de remover o magma do canal radicular, tornando as paredes dentinárias propícias para receber o material obturador.

Baker et al. (1975) compararam a eficiência de diferentes volumes de soluções irrigantes $(0,5,1,0,2,5$ e $5,0 \mathrm{~mL})$ com relação à limpeza e à remoção de debris no interior dos canais radiculares, utilizando MEV. As soluções utilizadas no estudo foram: solução fisiológica, peróxido de hidrogênio, $\mathrm{NaOCl}$ a 1\%, Glyoxide, Glyoxide e $\mathrm{NaOCl}$ a $1 \%$, RC Prep, RC Prep e $\mathrm{NaOCl}$ a 1\%, EDTA, EDTA e $\mathrm{NaOCl}$ a 1\%. Após a avaliação dos resultados, os autores não verificaram diferenças aparentes na eficiência das soluções testadas para remover os debris e que melhor limpeza dos canais radiculares era diretamente proporcional ao volume da solução irrigante utilizada.

Goldberg e Abramovich (1977), acreditando na necessidade de aumentar a permeabilidade da dentina radicular de modo a facilitar a ação dos medicamentos, realizaram um estudo utilizando o EDTA-C na remoção da smear layer e do smear plug formados durante $\mathrm{O}$ PQC dos canais radiculares. Os autores utilizaram soro fisiológico como solução irrigadora na fase de instrumentação dos canais radiculares. Em seguida, fraturaram longitudinalmente os dentes no sentido vestíbulo-lingual e aplicaram duas gotas de EDTA-C, com intervalo de $15 \mathrm{~min}$, em somente uma das metades. Após análise em MEV, relataram que a metade do dente que não recebeu tratamento com EDTA-C encontrava-se coberta por uma massa amorfa e os túbulos dentinários estavam parcial ou totalmente obstruídos por este material. As metades tratadas com EDTA-C mostravam-se livres desta massa 
amorfa, com os túbulos expostos e aumentados em diâmetro. Os autores concluíram que o EDTA-C traz benefícios à terapia endodôntica, pois auxilia na limpeza e desinfecção do canal radicular, facilita a ação das soluções irrigadoras e drogas devido ao aumento da permeabilidade radicular e, finalmente, condiciona as paredes dentinárias do canal para promover maior embricamento do material obturador.

Componentes extra e intracelulares de placa bacteriana cultivada foram avaliados quanto à sua capacidade de induzir reações inflamatórias na polpa dental por Bergenholtz (1977). Foram confeccionadas cavidades classe $V$ na face vestibular de dentes de macacos e componentes bacterianos liofilizados foram selados nas cavidades isoladamente ou seguidos de aplicação tópica de uma solução com os mesmos componentes em PBS. Os animais foram sacrificados após $32 \mathrm{~h}$ e as polpas foram examinadas histologicamente. A formação de abscessos foi frequentemente encontrada. As reações severas que se desenvolveram foram independentes das espessuras da dentina remanescente. Os achados confirmam que produtos bacterianos aplicados em dentina exposta iniciam reação inflamatória na polpa, ou seja, os produtos bacterianos permearam toda a espessura da dentina até alcançar a polpa dental.

Goldman et al. (1981) testaram a eficiência de três soluções irrigadoras de uso endodôntico para remoção da camada de magma, utilizando uma agulha com perfuração lateral. Ao término do preparo do canal, os canais radiculares foram irrigados com $20 \mathrm{~mL}$ de uma das seguintes soluções: $\mathrm{NaOCl}$ a 5,25\%, TEGO (solução detergente de glicina dodecildiaminoetil a $1 \%$ ou REDTA (acetato dinitrilotetra-acetato dissódico neutralizado com $5 \mathrm{~N}$ de hidróxido de sódio). $\mathrm{O} \mathrm{NaOCl}$ a 5,25\% e o TEGO não removeram o magma dentinário. O REDTA foi a única solução eficiente, no entanto, não removeu os restos de tecido orgânico. Diante dos 
resultados, os autores recomendaram que combinações de soluções fossem feitas no sentido de se conseguir resultados tanto para remoção de tecido orgânico quanto de inorgânico.

No ano seguinte, Goldman et al. (1982) avaliaram diferentes combinações de substâncias irrigadoras com a finalidade de remover o magma dentinário e verificaram que a associação de soluções que atuem tanto em matéria orgânica quanto inorgânica é altamente vantajosa.

Yamada et al. (1983) testaram a eficiência do PQC realizado com instrumentos manuais e $\mathrm{NaOCl}$ a 5,25\%. A irrigação final foi feita com um total de 20 $\mathrm{mL}$ de soluções irrigantes isoladas ou combinadas: soro fisiológico, $\mathrm{NaOCl}$ a $5,25 \%$, EDTA a $17 \%$, EDTA a $8,5 \%$, ácido cítrico a $25 \%$, EDTA a $17 \%+\mathrm{NaOCl}$ a $5,25 \%$, EDTA a $8,5 \%+\mathrm{NaOCl}$ a $5,25 \%$, ácido cítrico a $25 \%+\mathrm{NaOCl}$ a $5,25 \%$. A observação das imagens em MEV mostrou que a irrigação final com EDTA a 17\% seguido de $\mathrm{NaOCl}$ a $5,25 \%$ foi a combinação mais eficaz para remoção do magma dentinário.

Pashley (1984) observou que a dentina, ao ser cortada, tanto por instrumentos manuais como rotatórios, produz considerável quantidade de magma dentinário. Tal magma é composto por muitas partículas pequenas de matriz de colágeno mineralizada, que se espraiam sobre a superfície de dentina. A presença ou ausência do magma dentinário tem grande interesse para os endodontistas, pois essa camada pode conter microrganismos que, por sua vez, podem permanecer no interior do canal radicular e constituir um reservatório de agente irritante. O autor enfatizou que a presença da camada de magma dentinário influi sobremaneira na permeabilidade da dentina, pois oblitera os túbulos dentinários, reduzindo, assim, a área de difusão. 
Czonstkowsky, Wilson e Holstein (1990) comentam que embora dentes infectados tenham sido tratados com sucesso por gerações na presença de magma dentinário, a remoção desta camada é recomendável pois representa uma barreira para um contato íntimo entre o material obturador e as paredes do canal. Os autores recomendam como protocolo para irrigação final, o $\mathrm{NaOCl}$ a 5,25\% seguido de ácido cítrico a $6 \%$ ou EDTA a $17 \%$ para remover o magma dentinário e abrir os túbulos dentinários, produzindo uma superfície livre de debris.

Em 1993, preocupados em otimizar a limpeza final da cavidade endodôntica, Paiva e Antoniazzi recomendaram o uso do EDTA-T a $17 \%$. Esta solução associa um ácido fraco com poder quelante (EDTA) a um detergente capaz de diminuir a tensão superficial, facilitando o contato entre a solução e as paredes do canal.

Barkhordar et al. (1997) investigaram o efeito da doxiciclina no magma dentinário formado sobre as paredes do canal radicular após PQC e provaram que este antibiótico remove o magma dentinário com eficiência. Os autores ainda tecem comentários sobre o potente efeito anticolagenase quando utilizado topicamente e também sobre sua substantividade. Tukusuda e Gabler (1993) já comentavam sobre os benefícios dos antibióticos da família das tetraciclinas no tratamento de doenças periodontais devido às suas propriedades antimicrobianas, anti-colagenase e antinflamatória.

Zinng, Sakura e Moura (1997) avaliaram a eficiência na remoção do magma dentinário das paredes de canais radiculares de dentes humanos através da MEV. Os espécimes foram divididos em três grupos de acordo com a substância a ser empregada para irrigação final: EDTA, EDTA-T ou ácido cítrico ativados por ultrasom durante $1 \mathrm{~min}$. Após análise das eletromicrografias, os autores constataram a eficiência do EDTA-T na remoção do magma dentinário das paredes do canal. Os 
autores também verificaram que a limpeza era melhor nos terços cervical e médio e pior no terço apical.

Scelza (1998) estudou a capacidade de limpeza e remoção do magma dentinário do canal radicular empregando três conjuntos distintos de soluções irrigadoras e concluiu que a associação $\mathrm{NaOCl}$ a 0,5\% + EDTA-T foi mais eficiente do que $\mathrm{NaOCl}$ a $1 \%$ + ácido cítrico a $10 \%$ e ao $\mathrm{NaOCl}$ a $5,25 \%$ + água oxigenada.

Takeda et al. (1999) compararam os efeitos de três irrigantes endodônticos e dois tipos de laser sobre o magma dentinário criado pela instrumentação manual. Os adjuntos utilizados durante a instrumentação foram $\mathrm{NaOCl}$ a 5,25\% e peróxido de hidrogênio a $3 \%$. Os espécimes foram divididos de acordo com o método para remoção do magma: EDTA a 17\%, ácido fosfórico a 6\%, ácido cítrico a 6\%, laser de $\mathrm{CO}_{2}$ ou laser Er:YAG. Os espécimes irrigados com EDTA a 17\% mostraram superfícies radiculares limpas no terço médio, porém, em alguns espécimes, o terço apical apresentou magma. Os espécimes irrigados tanto com ácido fosfórico quanto com ácido cítrico apresentaram superfícies bastante limpas no terço médio, mas alguns espécimes apresentaram pequena quantidade de magma no terço apical. Os canais irradiados com laser de $\mathrm{CO}_{2}$ mostraram paredes livres de magma dentinário, derretimento da superfície e recristalização tanto nos terços médio quanto cervical. Finalmente, os canais irradiados com laser de Er:YAG revelaram ausência de magma dentinário com túbulos dentinários abertos nos terços médio e apical. Os autores comentaram sobre a descalcificação exagerada obtida com as soluções ácidas em que os túbulos dentinários foram demasiadamente alargados revelando a rede de colágeno de uma dentina intertubular amolecida.

Scelza, Antoniazzi e Scelza (2000) estudaram o grau de remoção de remanescentes pulpares e magma dentinário após irrigação final com três regimes 
diferentes: $\mathrm{NaOCl}$ a $1 \%$ + ácido cítrico a $10 \%$ + água destilada, $\mathrm{NaOCl}$ a $0,5 \%$ + EDTA-T a $17 \%$ e $\mathrm{NaOCl}$ a $5 \%$ + água oxigenada a $3 \%+\mathrm{NaOCl}$ a $5 \%$. Os canais foram irrigados por 4 min. A combinação $\mathrm{NaOCl}$ a $1 \%$ + ácido cítrico a $10 \%$ + água destilada se comportou de forma semelhante à combinação $\mathrm{NaOCl}$ a $0,5 \%$ + EDTAT a 17\%, que apresentaram maior quantidade de túbulos visíveis do que a combinação $\mathrm{NaOCl}$ a $5 \%$ + água oxigenada a $3 \%+\mathrm{NaOCl}$ a $5 \%$. O terço cervical apresentou maior quantidade de túbulos visíveis do que os terços médio e apical.

Guerisoli et al. (2002) analisaram a eficiência do NaOCl associado ao EDTA-C e agitação ultrassônica na remoção do magma dentinário. Os autores concluíram que a associação $\mathrm{NaOCl}+$ EDTA-C removeu eficientemente o magma das paredes do canal. $\mathrm{O} \mathrm{NaOCl}$ a $1 \%$ isoladamente e a água destilada não foram capazes de remover o magma. Quando os grupos foram examinados separadamente, não houve diferença entre a quantidade de magma dentinário encontrada nas regiões cervical, média e apical do canal.

Yang e Bae (2002) avaliaram o efeito da presença ou ausência do magma dentinário sobre a adesão de Prevotella nigrescens à dentina do canal radicular. Dez $\mathrm{mL}$ de soro fisiológico (grupos 1 e 4), $10 \mathrm{~mL}$ de $\mathrm{NaOCl}$ a 3,5\% (grupos 2 e 5) e 10 $\mathrm{mL}$ de EDTA (grupos 3 e 6) foram usados como solução irrigante durante o PQC. Após clivagem e esterilização com gás de óxido de etileno, as amostras dos grupos 1,2 e 3 foram inoculadas com $P$. nigrescens. Foi observado magma dentinário cobrindo todas as paredes do canal após PQC. Quando NaOCl e EDTA foram aplicados, o magma dentinário foi removido e as entradas dos túbulos dentinários foram abertas. Um número significantemente maior de bactérias foi encontrado aderido às paredes dos canais nos quais o magma dentinário estava presente. Os autores ainda comentaram que se o magma produzido durante o preparo do canal 
promoveu adesão e colonização bacteriana, ele pode aumentar a probabilidade de recontaminação do canal.

Cardoso de Menezes, Zanet e Valera (2003) avaliaram a capacidade de remoção do magma dentinário das paredes de canais radiculares preparados e irrigados com $\mathrm{NaOCl}$ a 2,5\%, $\mathrm{NaOCl}$ a 2,5\% e gluconato de clorexidina a $2 \%$, associados ou não a EDTA a 17\%. O emprego do EDTA melhorou significantemente a remoção do magma dentinário independente das substâncias usadas durante o preparo do canal. No geral, os diferentes terços do canal apresentaram aparência semelhante, dentro do mesmo grupo.

Scelza, Teixeira e Scelza (2003) avaliaram a capacidade de quelação dos íons cálcio da dentina do canal radicular quando da irrigação com EDTA-T, ácido cítrico a $10 \%$ e EDTA em 3, 10 e 15 min. Após o preparo dos canais, os dentes foram divididos em nove grupos de acordo com a solução envolvida e o tempo dispensado para o procedimento. Aos 3 min, não houve diferença na quelação dos íons cálcio quando o ácido cítrico e o EDTA foram utilizados. O EDTA-T apresentou menor eficácia quanto à quelação dos íons cálcio. Nos tempos de 10 e 15 min não foram encontradas diferenças estatísticas entre o ácido cítrico e o EDTA ou entre o EDTA e o EDTA-T, no entanto, o ácido cítrico foi melhor do que o EDTA-T.

Yamashita et al. (2003) avaliaram o grau de limpeza das paredes radiculares após irrigação com diferentes soluções: solução fisiológica, clorexidina a $2 \%, \mathrm{NaOCl}$ e $\mathrm{NaOCl}$ a $2,5 \%+$ EDTA. A melhor limpeza foi obtida quando o $\mathrm{NaOCl}$ a $2,5 \%+0$ EDTA foram utilizados, seguidos do $\mathrm{NaOCl}$ a 2,5\%. O grau de limpeza do $\mathrm{NaOCl}$ a $2,5 \%$ foi similar ao da clorexidina somente no terço cervical. A limpeza obtida com solução fisiológica e clorexidina a $2 \%$ foi similar em todos os terços e pior do que $\mathrm{NaOCl}$ e $\mathrm{NaOCl}$ a 2,5\% + EDTA. No geral, o terço apical de todos os grupos 
apresentou maior quantidade de smear layer do que nas outras áreas do canal radicular.

Scelza, Pierro e Scelza (2004) analisaram a interferência do tempo de irrigação (3, 10 e 15 min) na capacidade de remoção do magma dentinário do EDTAT, EDTA e ácido cítrico a $10 \%$. Os canais foram instrumentados e os espécimes divididos em nove grupos de acordo com a substância irrigadora e o tempo para irrigação final. Após análise das eletromicrografias, os autores concluíram que os três agentes irrigadores foram efetivos no tempo de 3 min e não apresentaram maior eficácia com a progressão do tempo.

Torabinejad et al. (2003b) compararam a irrigação final de canais instrumentados com uma dessas soluções: água destilada, $\mathrm{NaOCI}$ a 5,25\%, EDTA a $17 \%$, ou $M T A D^{\circledR}$. A análise da superfície com MEV mostrou que o $M T A D^{\circledR}$ removeu o magma de maneira mais eficiente do que o $\operatorname{EDTA}_{\text {e que }}$ $\mathrm{MTAD}^{\circledR}$ não alterou a estrutura dos túbulos dentinários. Os autores também comentaram sobre as vantagens da associação dos componentes, capazes de agir tanto em matéria orgânica quanto inorgânica.

Torabinejad et al. (2003a) analisaram o efeito de várias concentrações de $\mathrm{NaOCl}$ como irrigante final antes do uso do $\mathrm{MTAD}^{\circledR}$ como agente de irrigação para remoção do magma dentinário. Durante o preparo do canal, água destilada, quatro diferentes concentrações de $\mathrm{NaOCl}$ ou $\mathrm{MTAD}^{\circledR}$ foram usadas como irrigantes. Os canais foram então tratados por $2 \min$ com $5 \mathrm{~mL}$ de uma das seguintes soluções para irrigação final: $\mathrm{NaOCl}$ a $5,25 \%$, agua destilada, EDTA a $17 \%$ ou $\mathrm{MTAD}^{\circledR}$. A presença ou ausência de magma e a quantidade de erosão na superfície das paredes do canal radicular nos terços cervical, médio e apical foram examinadas sob MEV. Os resultados mostraram que, embora o $M T A D^{\circledR}$ remova a maioria do magma 
quando usado como irrigante intracanal, remanescentes de componentes orgânicos permanecem espalhados na superfície das paredes do canal. A eficiência do MTAD ${ }^{\circledR}$ em remover completamente o magma é aumentada quando $\mathrm{NaOCl}$ em baixas concentrações é empregado como irrigante intracanal antes da irrigação final com $M T A D^{\circledR}$. Este procedimento parece não alterar significantemente a estrutura dos túbulos dentinários.

García-Godoy et al. (2005) compararam a capacidade de remoção do magma dentinário e também a estrutura da camada formada após o uso das soluções de EDTA ou $M T A D^{\circledR}$, empregadas para irrigação final. Os dentes foram instrumentados empregando-se $\mathrm{NaOCl}$ a 1,3\% como substância auxiliar, seguido de irrigação final com EDTA a $17 \%$, MTAD $^{\circledR}$ ou solução salina (controle negativo). As raízes foram obturadas com com guta-percha e cimento Endo Rez. Os espécimes foram analisados em MET para se avaliar as imperfeições no selamento e nanoinfiltração. Apos irrigação com $\mathrm{NaOCl}$ e irrigação final com $\mathrm{MTAD}^{\circledR}$ ou EDTA a $17 \%$, o magma foi totalmente removido das paredes do canal. Tanto o MTAD $^{\circledR}$ quanto o EDTA provocaram colapso da matriz de dentina, ou seja, desmineralização, o que poderia ter impedido a formação de uma camada híbrida entre o cimento e a parede dentinária de melhor qualidade. Apesar destes resultados, os autores encorajam a remoção do magma após a preparo do canal.

Teixeira, Felippe e Felippe (2005) verificaram a influência do tempo de irrigação com EDTA a $15 \%$ e $\mathrm{NaOCl}$ a $1 \%$ sobre a remoção do magma dentinário intracanal. Após PQC, os canais foram irrigados com $3 \mathrm{~mL}$ de EDTA seguido de irrigação com $3 \mathrm{~mL}$ de $\mathrm{NaOCl}$ por 1 min (grupo 1), 3 min (grupo 2) e por 5 min (grupo 3). O grupo controle não recebeu irrigação final. Os espécimes foram clivados e as paredes dentinárias dos diferentes terços do canal foram avaliadas por escores de 
acordo com a quantidade de magma remanescente. No geral, a irrigação final com as soluções utilizadas por 1, 3 e 5 min foram igualmente efetivas na remoção do magma dentinário. Quando os terços foram analisados separadamente, o tempo de 1 min não foi suficiente para remover todo o magma na porção apical dos canais.

Torabinejad, Shabahang e Bahjri (2005) compararam os níveis de desconforto pós-operatório após limpeza e modelagem de canais radiculares, usando dois diferentes protocolos para remoção do magma dentinário. Os autores utilizaram-se de 73 pacientes necessitando de tratamento endodôntico que foram divididos em 2 grupos: no grupo $1, \mathrm{NaOCl}$ a $5,25 \%$ foi empregado como irrigante durante o PQC e o magma foi removido pela colocação de EDTA a $17 \%$ no canal por 1 min, seguido de irrigação final com $\mathrm{NaOCl}$ a 5,25\%; no grupo 2, $\mathrm{NaOCl}$ a $1,3 \%$ foi empregado como irrigante durante o PQC e o magma foi removido, colocando-se MTAD $^{\circledR}$ no canal por 5 min. Os dentes foram selados, deixando-se um penso de algodão estéril na câmara pulpar. Os pacientes anotaram o grau de desconforto em vários intervalos de tempo após a consulta, numa escala visual por uma semana. Não houve diferença estatística significante no grau de desconforto entre os dois grupos.

Tay et al. (2006) examinaram a estrutura da dentina intra-radicular de canais instrumentados apos irrigação com $\mathrm{NaOCl}$ seguidos de irrigação final com $\mathrm{MTAD}^{\circledR}$. Foram analisados os terços cervical, médio e apical dos canais usando-se MET. Para os grupos controle negativo e positivo foram utilizados água destilada e EDTA, respectivamente, sob as mesmas condições experimentais. Formaram-se camadas de 2 a $5 \mu \mathrm{m}$ de espessura produzidas nas paredes dos canais instrumentados que foram totalmente removidas pelo EDTA e pelo $M T A D^{\circledR}$ sob agitação. Ambos os irrigantes criaram uma zona de desmineralização da matriz de colágeno na dentina 
erodida e ao redor dos túbulos dentinários, sendo que o $M T A D^{\circledR}$ foi ligeiramente mais agressivo do que o EDTA. Eles constataram que estas zonas de desmineralização da dentina criam a oportunidade para hibridização da mesma pela infiltração de cimentos e/ ou adesivos hidrofílicos.

Khademi, Yazdizadeh e Feizianfard (2006) examinaram qual o alargamento mínimo necessário da região apical obtido com a instrumentação para uma efetiva penetração dos irrigantes e eliminação do magma dentinário. Raízes mésiovestibulares de primeiros molares inferiores foram instrumentadas, sendo que o alargamento da região apical foi \#20, \#25, \#30 ou \#35. Os resultados demonstraram que a instrumentação mínima da região apical deve ser realizada com instrumento \#30 para que a irrigação desta área seja feita com eficiência.

Mello et al. (2007) avaliaram a eficiência na remoção do magma dentinário de paredes de canais radiculares quando do emprego de algumas soluções para irrigação final. Os grupos foram formados de acordo com a solução a ser empregada para este fim, como a seguir: grupo 1 (controle) - soro fisiológico, grupo 2 hipoclorito de sódio a 1\%, grupo 3 - EDTA-T a 17\%, grupo 4 - clorexidina a 0,2\%, grupo 5 - hipoclorito de sódio a $1 \%$ seguido de EDTA-T a 17\%, grupo 6 - hipoclorito de sódio a $1 \%$ seguido de clorexidina a $0,2 \%$. O melhor desempenho ocorreu nos grupos em que se utilizou EDTA-T a 17\% e a associação hipoclorito de sódio a 1\% seguida de EDTA-T a $17 \%$.

\subsection{Estudos sobre a relação entre permeabilidade dentinária e remoção do magma dentinário}


Pashley, Michelich e Kehl (1981) examinaram o aspecto da dentina por MEV antes e após a remoção do magma dentinário com ácido cítrico e analisaram os efeitos deste tratamento na permeabilidade da dentina. Os autores verificaram que o ácido cítrico removeu o magma dentinário num espaço curto de tempo e que a permeabilidade dentinária aumentou após irrigação com o ácido.

Moura et al. (1988) avaliaram a permeabilidade dentinária radicular em dentes irrigados com $\mathrm{NaOCl}$ a $1 \%$, associado ao creme de ENDO-PTC, durante a instrumentação, e irrigação final com solução de Tergentol-Furacin, seguida ou não do emprego final de EDTA-C. Os autores correlacionaram a presença do magma como barreira à passagem do corante por meio da massa dentinária e constataram que o emprego do EDTA-C não alterou significantemente a permeabilidade da dentina.

Fogel e Pashley (1990) mediram a permeabilidade dentinária radicular antes e após o preparo do canal e antes e após remoção do magma dentinário com $\mathrm{NaOCl}$, ácido cítrico a $50 \%$ ou oxalato de monopotássio-monohidrogênio a $3 \%$. A instrumentação reduziu a permeabilidade da dentina entre 25 e 49\%. A permeabilidade não foi afetada pelo $\mathrm{NaOCl}$ a $5 \%$ mas aumentou diversas vezes após o tratamento com ácido cítrico a $50 \%$ por 2 min. O tratamento com o oxalato de monopotássio-monohidrogênio a 3\% diminuiu a permeabilidade da dentina a níveis abaixo daqueles da camada de magma dentinário devido à produção de um precipitado cristalino.

Tao, Anderson e Pashley (1991) quantificaram os efeitos sequenciais dos procedimentos endodônticos sobre a permeabilidade da dentina radicular in vitro. As 
medições foram feitas antes e após tais procedimentos. Os autores também mediram a espessura dentinária, as alterações no diâmetro intracanal e as alterações na superfície intracanal. Os resultados mostraram que a instrumentação com limas tipo K, sozinhas ou associadas às brocas de Gates-Glidden, não alteraram a permeabilidade radicular quando o cemento permaneceu intacto. Após a remoção do cemento, a formação de smear layer e smear plugs tendeu a compensar o aumento esperado na permeabilidade dentinária criada pela área aumentada da superfície intracanal e também pela diminuição da espessura da dentina. $O$ tratamento com EDTA no interior dos canais não aumentou significantemente a permeabilidade da dentina. O uso de limas tipo $\mathrm{K}$, seguidas de brocas GatesGlidden, removeu mais dentina na região cervical, aumentou a superfície de área intracanal e aumentou também a permeabilidade dentinária quando comparado ao uso das limas tipo $\mathrm{K}$ isoladamente.

Galvan et al. (1994) investigaram a permeabilidade dentinária de dentes humanos extraídos antes e após a remoção do magma dentinário com EDTA e $\mathrm{NaOCl}$ a $5 \%$. Os resultados mostraram redução da difusão do indicador após a remoção do magma dentinário. Os autores justificaram o achado dizendo que o EDTA pode não ter sido capaz de quelar completamente os íons cálcio liberados formando assim, fosfato de cálcio dentro dos túbulos, tornando a dentina menos permeável, ou ainda, o EDTA não fora capaz de remover completamente o smear plug.

Guignes, Faure e Maurette (1996) avaliaram a permeabilidade dentinária após três protocolos distintos de preparo do canal: manual (limas tipo $\mathrm{K} \mathrm{e} \mathrm{H}$, preparo ultrassônico e preparo manual) com $\mathrm{NaOCl}$ e EDTA. A superfície do canal foi observada sob MEV para permitir correlações entre as variações da permeabilidade 
e a quantidade de magma dentinário sobre as paredes do canal. Os autores concluíram que há uma relação inversamente proporcional entre a permeabilidade dentinária radicular e a quantidade do magma dentinário; em outras palavras, quanto maior a quantidade do magma dentinário presente nas paredes dos canais radiculares, menor a permeabilidade dentinária. O emprego do EDTA induziu a um aumento considerável na permeabilidade radicular. O uso do ultrassom produziu um efeito similar, porém mais fraco.

Raldi e Lage-Marques (2003) avaliaram os efeitos da interação de substâncias irrigantes, medicação intracanal e laser Er:YAG na permeabilidade dentinária do sistema endodôntico. Após o PQC, os espécimes foram divididos em sete grupos experimentais: grupos I e II - irrigação final com solução de EDTA-T e ácido cítrico, respectivamente; grupos III e IV - irrigação final com EDTA-T e ácido cítrico, respectivamente, mais a associação entre solução irrigante e laser Er:YAG; grupos V e VI - irrigação final com EDTA-T e ácido cítrico, respectivamente, mais a associação entre medicação intracanal NDP e laser Er:YAG, e grupo VII (controle) irrigação final com água destilada. Existiram diferenças estatisticamente significantes quanto à penetração da solução corante-medicação intracanal nos diferentes grupos. Os grupos III e IV apresentaram menores valores de permeabilidade dentinária quando comparados aos outros e, finalmente, os melhores resultados foram obtidos quando da interação entre a solução irrigante desmineralizadora e a associação medicação intracanal/laser Er:YAG (grupos V e VI). Nesses, constatouse que a diferença de penetração da solução corante-medicação intracanal no terço apical foi, em média, $29 \%$ maior do que nos demais grupos.

Após a revisão da literatura, pôde-se constatar a importância do papel da permeabilidade dentinária e do magma dentinário dentro do tratamento endodôntico. 
Mesmo com tantos estudos desenvolvidos ao redor destes temas, alguns aspectos ainda permanecem não esclarecidos e merecem ser pesquisados. 


\section{PROPOSIÇÃO}

Este trabalho teve como objetivo:

1. analisar possíveis diferenças e seus significados na permeabilidade dentinária radicular quando da irrigação-aspiração final, utilizando diversas substâncias irrigadoras após o preparo químico-cirúrgico padrão;

2. avaliar, sob MEV, a eficiência de diferentes soluções preconizadas para a irrigação-aspiração final do canal radicular quanto à remoção do magma dentinário;

3. identificar as alterações ocorridas nos diferentes terços do canal radicular em ambos os testes realizados - permeabilidade dentinária radicular e remoção do magma dentinário radicular;

4. desenvolver uma metodologia que possibilite a realização de ambos os testes, permeabilidade dentinária radicular e magma dentinário por meio de substância corante e MEV, nos mesmos espécimes;

5. verificar a correlação dos resultados estatísticos entre a permeabilidade dentinária radicular e a presença de magma dentinário quando da comparação entre as substâncias entre si, segundo os terços radiculares e, como um todo e no confronto dos terços ao se empregar a mesma substância irrigadora. 


\section{MATERIAL E MÉTODOS}

\subsection{Material}

48 dentes unirradiculares humanos cedidos pelo Banco de Dentes Humanos da Faculdade de Odontologia da Universidade de São Paulo Agulhas para irrigação ProRinse (Dentsply-Tulsa Dental, Tulsa, OK, EUA) Algodão (Coltène/Whaledent Inc., Cuyahoga Falls, Ohio, EUA) BioPure MTAD (Sigma Aldrich Co., St Louis, MO, EUA) Brocas Largo \# 1 e 2 (Dentsply-Tulsa Dental, Tulsa, OK, EUA)

Câmera digital Nikon Coolpix 4500 (Nikon Co., Tóquio, Japão)

Cânulas suctoras (Ultradent, South Jordan, UT, EUA)

Cera utilidade (Ronkonkoma, NY, EUA)

Cianoacrilato de etila (Sun Medical Co. Ltd, Kioto, Japão)

Clivador (conforme modelo da Disciplina de Endodontia da Faculdade de Odontologia da USP)

Cones de papel absorvente (Dentsply-Tulsa Dental, Tulsa, OK, EUA)

Creme Endo-PTC (Farmácia de manipulação Fórmula \& Ação, São Paulo, SP)

Discos de aço diamantados (Adaco, Köln, Alemanha)

EDTA a 17\% (manipulado no laboratório de bioquímica da Faculdade de

Odontologia da Universidade de British Columbia, Vancouver, BC, Canadá)

EDTA-T a 17\% (Farmácia de manipulação Fórmula \& Ação, São Paulo, SP)

Estufa a $37^{\circ} \mathrm{C}$ (Precision Scientific, Chicago, ILL, EUA) 
Explorador n05 (Blue Lake Products, Irvine, CA, EUA)

Frascos para acondicionamento dos espécimes

Fresas diamantadas 1012, 1013 e 3083 (SS White Burs Inc., Lakewood, NJ, EUA)

Gaze (Coltène/Whaledent Inc., Cuyahoga Falls, OH, EUA)

Hipoclorito de sódio a 1\% (manipulado no laboratório de bioquímica da Faculdade de

Odontologia da Universidade de British Columbia, Vancouver, BC, Canadá)

Limas endodônticas Hedströen, $1^{a}$ série (Dentsply-Tulsa Dental, Tulsa, OK, EUA)

Limas endodônticas ProTaper (Dentsply-Tulsa Dental, Tulsa, OK, EUA)

Limas endodônticas tipo $\mathrm{K}, 1^{\mathrm{a}}$ série (Dentsply-Tulsa Dental, Tulsa, OK, EUA)

Limas endodônticas tipo K, série especial (Dentsply-Tulsa Dental, Tulsa, OK, EUA)

Lupa de 10 aumentos (D. F. Vasconcelos, São Paulo, SP)

Luvas de procedimento (Cardinal Health, Toronto, ON, Canadá)

Microscópio cirúrgico (Global Surgical Co., St. Louis, MO, EUA)

Microscópio eletrônico de varredura S-260 (Leo Ltd, Cambridge, Cambridgeshire, Inglaterra)

Papel de filtro (Hangzhou Special Paper Co., Fuyang,China)

Películas radiográficas (Kodak Co., Rochester, NY, EUA)

Pinça clínica (Blue Lake Products, Irvine, CA, EUA)

Programa estatístico Bioestat 3.0 (programa desenvolvido pela Universidade Federal do Pará, Belém, PA)

Programa ImageLab 2.3 (programa desenvolvido pelo laboratório de informática dedicado à disciplina de Patologia da Faculdade de Odontologia da Universidade de São Paulo, São Paulo, SP)

Seringas plásticas 5 mL (Dentsply-Tulsa Dental, Tulsa, OK, EUA) 
Solução de azul de metileno a 0,5\% (manipulada no laboratório de bioquímica da Faculdade de Odontologia da Universidade de British Columbia, Vancouver, BC, Canadá)

Solução de timol a 1\% (manipulada no laboratório de bioquímica da Faculdade de Odontologia da Universidade de British Columbia, Vancouver, BC, Canadá) Solução fisiológica (manipulada no laboratório de bioquímica da Faculdade de Odontologia da Universidade de British Columbia, Vancouver, BC, Canadá) 


\subsection{Métodos}

4.2.1 Atendimento às normas de bioética

Anteriormente ao início da pesquisa, o projeto foi encaminhado ao Comitê de Ética em Pesquisa da Faculdade de Odontologia da Universidade de São Paulo (Anexo 1).

\subsubsection{Seleção da amostra}

Foram selecionados 40 (quarenta) dentes humanos unirradiculares (superiores e inferiores), fornecidos pelo Banco de Dentes Humanos da Faculdade de Odontologia da Universidade de São Paulo. Os dentes foram radiografados para constatar a presença de canal único, com volume semelhante, formação radicular completa, ausência de reabsorções e de obturação endodôntica e mantidos em solução de timol a $1 \%$ em geladeira a $4^{\circ} \mathrm{C}$ até o momento do uso.

\subsubsection{Preparo da amostra}


4.2.3.1 manipulação prévia dos espécimes

Após limpeza, os espécimes foram mantidos em solução fisiológica por 72 h para equalizar o padrão de hidratação.

4.2.3.2 cirurgia de acesso e preparo da entrada do canal

A cirurgia de acesso foi realizada com brocas diamantadas compatíveis com o volume das câmaras pulpares de cada dente (1012 ou 1013) e forma de conveniência feita com brocas 3083. A seguir, o terço cervical do canal foi preparado com brocas de Largo \# 1 e 2.

\subsubsection{3 esvaziamento e preparo químico-cirúrgico}

O comprimento real de cada dente foi estabelecido introduzindo-se uma lima tipo K \# 10 até a abertura foraminal apical, fato confirmado com o uso de uma lupa de 10 aumentos. Desta medida recuou-se $0,5 \mathrm{~mm}$ para estabelecer o comprimento de trabalho de cada dente. O eventual conteúdo do canal foi removido com limas Hedströen e $\mathrm{NaOCl}$ a 1\%. O preparo químico-cirúrgico foi iniciado com instrumentos manuais \#15 ou \#20, dependendo do diâmetro inicial do canal. Os instrumentos 
rotatórios foram então empregados utilizando-se a sequência de limas rotatórias ProTaper (de S1 a F3) e o preparo do batente apical feito com limas manuais tipo K \#35. Como substâncias químicas auxiliares foram utilizados o creme Endo-PTC neutralizado pelo $\mathrm{NaOCl}$ a $1 \%$ segundo a técnica de Paiva e Antoniazzi (1993). A cada troca de lima, o canal era irrigado com $1 \mathrm{~mL}$ de $\mathrm{NaOCl}$, em seguida aspirado e o creme Endo-PTC renovado. Findo o preparo químico-cirúrgico, os canais radiculares foram irrigados com $5 \mathrm{~mL}$ de $\mathrm{NaOCl}$ a 1\%. Um total de $10 \mathrm{~mL}$ de $\mathrm{NaOCl}$ foi usado para o preparo químico-cirúrgico de cada dente. O tempo aproximado de preparo químico-cirúrgico de cada espécime foi de 8 a 10 min.

\subsubsection{Irrigação-aspiração experimental}

4.2.4.1 formação dos grupos

Os 40 espécimes foram divididos aleatoriamente em quatro grupos de 10 dentes cada, de acordo com a solução irrigadora a ser empregada para irrigaçãoaspiração final do canal radicular (Quadro 4.1). 


\begin{tabular}{|c|c|}
\hline Grupos & Soluções para irrigação-aspiração final \\
\hline I & NaOCl a 1\% \\
\hline II & EDTA a 17\% \\
\hline III & EDTA-T a 17\% \\
\hline IV & BioPure - MTAD \\
\hline
\end{tabular}

Quadro 4.1 - Divisão dos grupos experimentais de acordo com as soluções para irrigação-aspiração final

\subsubsection{2 irrigação-aspiração final e secagem do canal}

Para a irrigação-aspiração final de todos os espécimes, foram acopladas agulhas de irrigação de calibre 30 a seringas plásticas de $5 \mathrm{~mL}$. As agulhas foram introduzidas a $2 \mathrm{~mm}$ aquém do comprimento de trabalho (SEDGLEY et al., 2005) com movimentos de vaivém com amplitude de 2 a $3 \mathrm{~mm}$. As irrigações foram realizadas da seguinte forma: irrigação-aspiração dos espécimes dos grupos I, II e III utilizando-se $5 \mathrm{~mL}$ das respectivas soluções irrigadoras durante $3 \mathrm{~min}$. Diferentemente dos outros grupos, a irrigação-aspiração dos espécimes do grupo IV foi realizada inicialmente, com $1 \mathrm{~mL}$ da solução irrigadora que permaneceu no canal radicular por 5 min e, somente após este período, empregou-se os $4 \mathrm{~mL}$ restantes, segundo o protocolo estabelecido pelo fabricante. Concluída a fase de irrigaçãoaspiração final, os canais foram secos por aspiração com cânula suctora seguida de cones de papel absorvente. 
4.2.5 Preparo dos dentes para o estudo da permeabilidade dentinária

\subsubsection{1 impermeabilização externa e injeção do corante}

Todos os dentes foram impermeabilizados externamente com duas demãos de cianoacrilato de etila (ROBAZZA, 1991), tomando-se o cuidado para o impermeabilizante não penetrar para o interior do canal radicular, movimentando-se uma lima \# 10 no forame apical. Os frascos utilizados para armazenagem dos espécimes tinham $10 \mathrm{~mm}$ de diâmetro, o que permitiu que os dentes permanecessem em posição vertical com a coroa voltada para cima. O corante azul de metileno a $0,5 \%$ foi colocado em seringa tipo Luer, na qual foi acoplada uma agulha de calibre 30. O corante foi injetado no canal desde o terço apical até o preenchimento total da cavidade pulpar. Solução salina foi dispensada no frasco até o nível da junção amelo-cementária para manter a umidade relativa do ar (Figura 4.1). Os espécimes permaneceram com corante por $48 \mathrm{~h}$, em estufa a $37^{\circ} \mathrm{C}$ (ANTONIAZZI et al., 1968) nos frascos devidamente tampados.

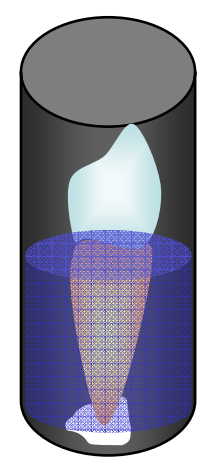

Figura 4.1 - Espécime em posição vertical no frasco preenchido com solução salina 
4.2.5.2 remoção dos espécimes do corante e confecção dos sulcos de orientação

Decorridas as $48 \mathrm{~h}$, os espécimes foram retirados dos frascos, lavados em água corrente por 30 min para remoção do excesso do corante e secos em papel de filtro. As cirurgias de acesso foram seladas com cera utilidade para impedir que raspas de dentina penetrassem para o interior da cavidade pulpar. Foram confeccionados sulcos transversais com discos diamantados em baixa rotação e sem refrigeração nos limites entre os três terços da raiz (cervical, médio e apical). Também foram confeccionados dois sulcos longitudinais de orientação, um na face mesial e outro na face distal de cada espécime para posterior clivagem e análise em MEV (Figura 4.2).

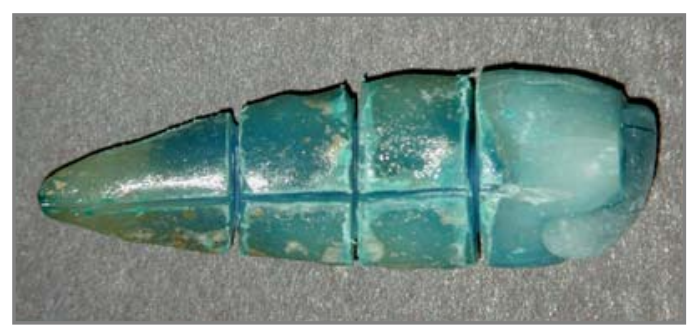

Figura 4.2 - Espécime após confecção dos sulcos longitudinais e transversais

\subsubsection{3 clivagem transversal}


As coroas dos dentes foram removidas por clivagem (Bombana et al., 1993). A seguir, as raízes foram também clivadas no sentido transversal, obtendo-se três fragmentos, um cervical, um médio e um apical (Figura 4.3).

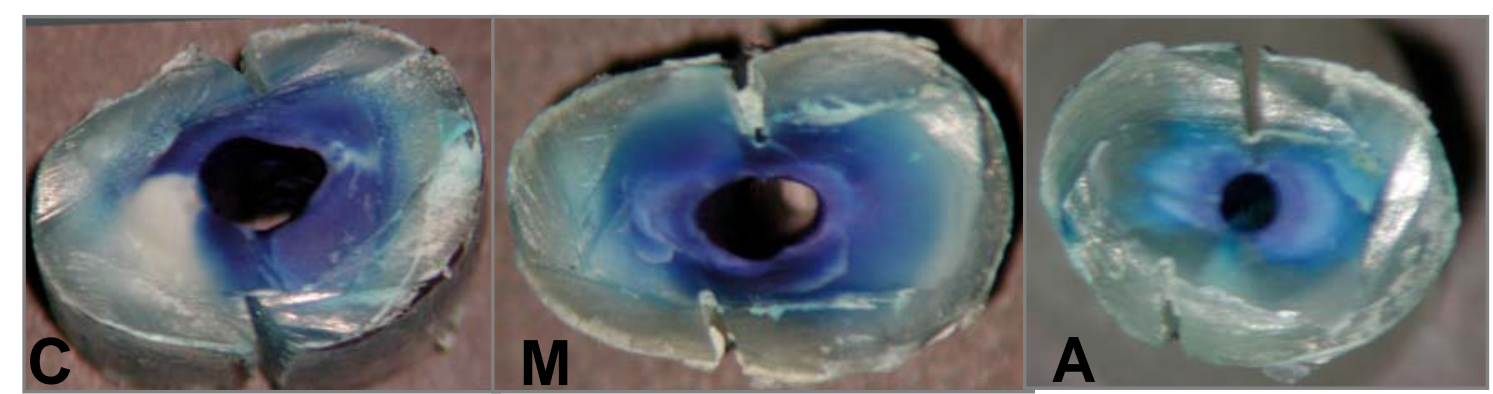

Figura 4.3 - Fragmentos obtidos após a clivagem transversal segundo os terços radiculares (da esquerda para a direita: $\mathrm{C}=$ cervical; $\mathrm{M}=$ médio; $\mathrm{A}=$ apical)

\subsubsection{4 obtenção das imagens}

Para a obtenção das imagens, a face selecionada para ser fotografada era sempre aquela voltada para a coroa do dente. Cada fragmento foi fotografado sob microscópio cirúrgico com aumento de 12,8 vezes e resolução de 2048 x 1536 pixels. As imagens foram armazenadas em CD para posterior mensuração da penetração do corante nos três fragmentos.

\subsubsection{5 mensuração da penetração do corante}

As imagens foram reduzidas para o tamanho de $1000 \times 750$ pixels a fim de possibilitar a utilização das mesmas no programa Imagelab 2.3, utilizado para 
mensuração da penetração do corante na massa dentinária (Figura 4.4). Para cada corte, foi calculado o percentual da área corada em relação à área radicular total. Inicialmente, foi demarcada a área total do dente e posteriormente, a área do canal. A área do canal foi subtraída da área total do dente, determinando assim, a área da dentina (área do dente - área do canal = área da dentina). Delimitou-se então a área total corada, da qual foi subtraída a área do canal, obtendo-se assim a área corada (área total corada - área do canal = área corada). A porcentagem da área corada foi determinada de acordo com o cálculo a seguir:

área corada $($ em porcentagem $)=($ área corada $\times 100) /$ área da dentina

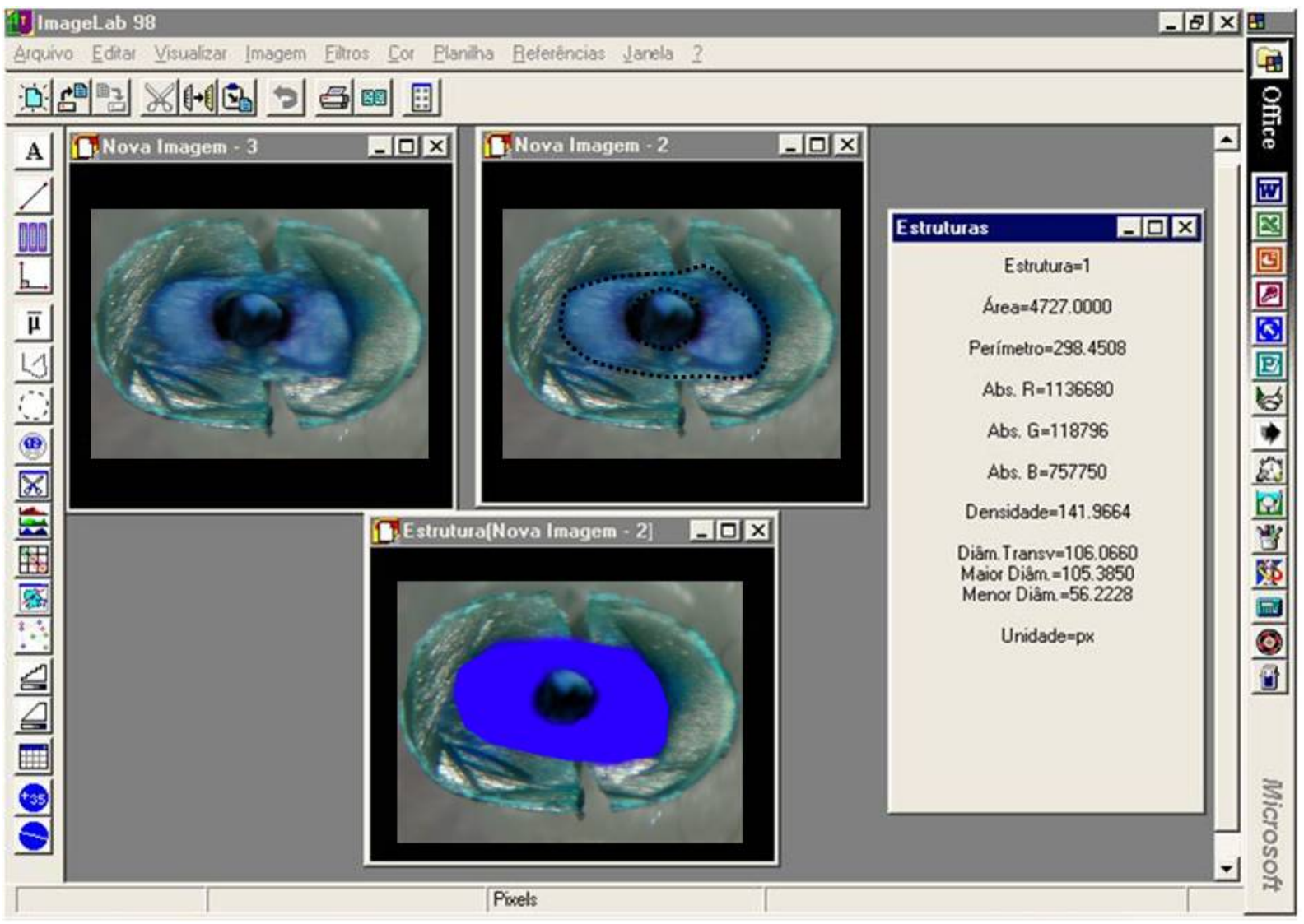

Figura 4.4 - Processamento da imagem no programa ImageLab 
4.2.6 Preparo dos dentes para o estudo sobre remoção do magma dentinário Os mesmos espécimes foram posteriormente preparados para análise da limpeza da superfície dentinária dos canais radiculares.

4.2.6.1 clivagem longitudinal

Cada fragmento foi novamente clivado, agora no sentido longitudinal, utilizando-se novamente do clivador (Bombana et al., 1993).

4.2.6.2 preparo dos dentes para análise sob MEV

Todos os fragmentos foram desidratados em álcool absoluto por $24 \mathrm{~h}$ e colocados em estufa a $37^{\circ} \mathrm{C}$ por $48 \mathrm{~h}$. Decorrido este período, os fragmentos foram montados em stubs de alumínio e cobertos com $25 \mu$ m de liga de ouro-paládio.

\subsubsection{3 observação sob MEV}

Os espécimes foram observados em MEV com 500 vezes de aumento. Toda a área do espécime foi varrida e a região mais expressiva (mais freqüentemente encontrada) de cada segmento foi selecionada e capturada. 


\subsubsection{4 avaliação das eletromicrografias}

As imagens foram analisadas quanto à limpeza da superfície dentinária por três avaliadores de acordo com o Quadro 4.2, conforme o critério proposto por Torabinejad et al. (2003b).

\begin{tabular}{|c|c|c|}
\hline Escore & Aspecto da parede dentinária & Definição \\
\hline 1 & Magma dentinário ausente & $\begin{array}{c}\text { Parede livre de debris e } \\
\text { túbulos dentinários limpos e } \\
\text { abertos }\end{array}$ \\
\hline 2 & $\begin{array}{c}\text { Quantidade moderada de } \\
\text { magma dentinário } \\
\text { Parede livre de debris ou } \\
\text { presença de debris cobrindo } \\
\text { parte da parede do canal e } \\
\text { debris no interior dos túbulos } \\
\text { dentinários }\end{array}$ \\
\hline 3 & $\begin{array}{c}\text { Grande quantidade de } \\
\text { magma dentinário }\end{array}$ & $\begin{array}{c}\text { Debris cobrindo a maior } \\
\text { parte da parede do canal } \\
\text { radicular e túbulos } \\
\text { dentinários }\end{array}$ \\
\hline
\end{tabular}

Quadro 4.2 - Critério utilizado para classificação da limpeza das paredes dentinárias após irrigação-aspiração final com as substâncias avaliadas

\subsubsection{Análise estatística}

O programa estatístico Bioestat 3.0 foi empregado para a análise dos dados. Quando a distribuição amostral foi normal, o teste paramétrico ANOVA foi utilizado e quando a distribuição amostral não foi normal, foi então utilizado o teste não-paramétrico de KruskalWallis, ambos com nível de significância de 5\%. Para a correlação de ambos os estudos, o teste de correlação de Pearson foi aplicado. 


\section{RESULTADOS}

\subsection{Estudo da permeabilidade dentinária}

No Apêndice A, encontram-se os dados originais, em percentual, da penetração do corante medido em pixels em cada secção transversal dos espécimes, assim como as médias dos diferentes grupos experimentais. Os valores percentuais submetidos ao teste de normalidade mostram distribuição amostral normal (Apêndice B). Desta forma empregou-se o teste estatístico paramétrico ANOVA com nível de significância de $\alpha=0,05$. As médias, desvios-padrões e resultados estatísticos encontram-se na Tabela 5.1.

Tabela 5.1 - Média (em porcentagem) da penetração do corante nos grupos avaliados e nos diferentes terços do canal radicular com os respectivos desvios padrão e níveis de significância de $5 \%$ entre si

\begin{tabular}{|c|c|c|c|c|}
\hline $\begin{array}{l}\text { Terços } \\
\text { Grupos }\end{array}$ & Cervical & Médio & Apical & TOTAL \\
\hline $\mathrm{I}$ & $49,48 \pm 10,397^{\mathrm{a} \Delta}$ & $47,51 \pm 17,68^{\mathrm{a} \Delta}$ & $35,63 \pm 12,07^{\mathrm{a} \Delta}$ & $44,21 \pm 14,60^{\Delta}$ \\
\hline II & $52,67 \pm 16,19^{a \Delta}$ & $46,20 \pm 12,29^{a \Delta}$ & $38,12 \pm 11,65^{a \Delta}$ & $45,66 \pm 14,35^{\Delta}$ \\
\hline III & $51,04 \pm 18,23^{a \Delta}$ & $43,36 \pm 17,76^{\mathrm{a} \Delta}$ & $21,66 \pm 12,09^{b \Delta}$ & $38,69 \pm 20,08^{\Delta}$ \\
\hline IV & $50,24 \pm 8,38^{a \Delta}$ & $48,89 \pm 10,03^{a \Delta}$ & $35,08 \pm 13,03^{a \Delta}$ & $44,74 \pm 12,48^{\Delta}$ \\
\hline TOTAL & $50,85 \pm 14,35^{a}$ & $46,49 \pm 13,52^{a}$ & $32,62 \pm 13,30^{a}$ & 43,32 \\
\hline
\end{tabular}

Letras iguais na mesma linha indicam grupos homogêneos estatisticamente não significantes $(p=0,05)$

Símbolos iguais na mesma coluna indicam grupos homogêneos estatisticamente não significantes $(p=0,05)$ 
Os resultados da ANOVA entre os grupos testados, no geral, mostram que não há diferença estatística significante quanto à permeabilidade dentinária (Apêndice D). Todas as substâncias irrigadoras empregadas permitem penetração dentinária semelhante à do corante azul de metileno ao longo da raiz analisada como um todo (Coluna Total da Tabela $5.1)$.

Quando em cada um dos terços do canal são comparadas as substâncias irrigadoras, não há diferença estatística significante, ou seja, a permeabilidade da dentina é semelhante após a irrigação final com as substâncias empregadas, tanto para o terço cervical quanto para o médio e terço apical (Colunas da Tabela 5.1).

Quando os terços do canal radicular são confrontados entre si com a mesma substância irrigadora, diferenças estatísticas são encontradas. Não há diferença estatística significante $(p>0,05)$ entre os terços nos grupos I, II e IV (Linhas da Tabela 5.1). No grupo III há diferença estatística significante quando se compara os terços cervical e médio com o terço apical $(p<0,05)$, sendo que o terço cervical apresenta maior penetração do corante quando comparado ao terço apical do canal radicular, assim como o terço médio apresenta maior infiltração do corante quando comparado ao terço apical. Não há diferença, no entanto, entre os terços cervical e médio.

Todos os resultados de significância estatística estão confirmados pelo teste de Tukey (Tabela 5.2).

Por fim, as Figuras 5.1 a 5.3 mostram espécimes dos grupos avaliados quanto à penetração do corante de acordo com os terços do canal radicular. 
Tabela 5.2 - Valores absolutos das diferenças entre as médias dos tratamentos segundo os terços radiculares e teste de Tukey $5 \%$

\begin{tabular}{|c|c|c|c|c|c|c|c|c|c|c|c|c|c|}
\hline \multirow{2}{*}{\multicolumn{2}{|c|}{$\begin{array}{l}\text { Grupos e } \\
\text { Terços } \\
\text { Grupos } \\
\text { e Terços }\end{array}$}} & \multicolumn{3}{|c|}{ Grupo I } & \multicolumn{3}{|c|}{ Grupo II } & \multicolumn{3}{|c|}{ Grupo III } & \multicolumn{3}{|c|}{ Grupo IV } \\
\hline & & C & M & A & C & M & A & C & M & A & C & M & A \\
\hline \multirow{2}{*}{ Grupo } & C & - & - & - & - & - & - & - & - & - & - & - & - \\
\hline & $\mathbf{M}$ & $1,97^{\mathrm{ns}}$ & - & - & - & - & - & - & - & - & - & - & - \\
\hline I & A & $13,84^{\mathrm{ns}}$ & $11,88^{\mathrm{ns}}$ & - & - & - & - & - & - & - & - & - & - \\
\hline Grupo & C & $3,18^{\text {ns }}$ & - & - & - & - & - & - & - & - & - & - & - \\
\hline \multirow{2}{*}{ II } & $M$ & - & $1,31^{\text {ns }}$ & - & $6,45^{\mathrm{ns}}$ & - & - & - & - & - & - & - & - \\
\hline & A & - & - & $2,49^{\text {ns }}$ & $14,53^{\text {ns }}$ & $8,08^{\text {ns }}$ & - & - & - & - & - & - & - \\
\hline Grupo & C & $1,56^{\mathrm{ns}}$ & - & - & $1,61^{\text {ns }}$ & - & - & - & - & - & - & - & - \\
\hline \multirow{2}{*}{ III } & $\mathbf{M}$ & - & $4,15^{\mathrm{ns}}$ & - & - & $2,84^{\mathrm{ns}}$ & - & $7,68^{\text {ns }}$ & - & - & - & - & - \\
\hline & A & - & - & $13,97^{\text {ns }}$ & - & - & $16,46^{\text {ns }}$ & $29,38^{s}$ & $21,70^{\mathrm{s}}$ & - & - & - & - \\
\hline \multirow{3}{*}{$\begin{array}{c}\text { Grupo } \\
\text { IV }\end{array}$} & C & $0,76^{\text {ns }}$ & - & - & $2,42^{\text {ns }}$ & - & - & $0,81^{n s}$ & - & - & - & - & - \\
\hline & $\mathbf{M}$ & - & $1,38^{\mathrm{ns}}$ & - & - & $2,69^{\text {ns }}$ & - & - & $5,53^{\text {ns }}$ & - & $1,34^{\mathrm{ns}}$ & - & - \\
\hline & A & - & - & $0,55^{\mathrm{ns}}$ & - & - & $3,04^{\mathrm{ns}}$ & - & - & $13,42^{\mathrm{ns}}$ & $15,16^{\mathrm{s}}$ & $13,81^{\text {ns }}$ & - \\
\hline
\end{tabular}



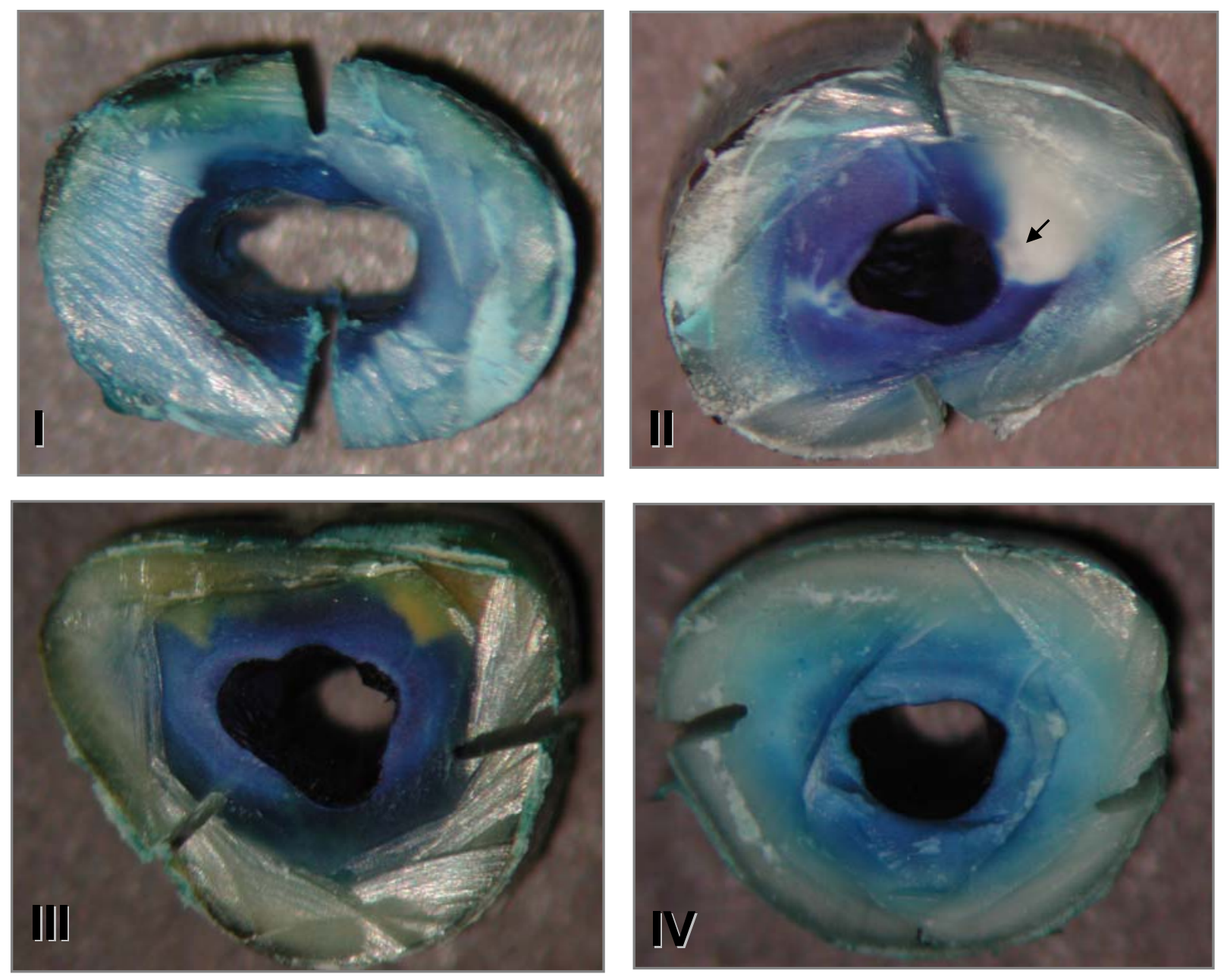

Figura 5.1 - Terços cervicais dos espécimes dos grupos submetidos ao estudo da permeabilidade dentinária - I (NaOCI); II (EDTA); III (EDTA-T); e, IV (MTAD ${ }^{\circledR}$ ). Observa-se que em todos os espécimes houve grande penetração do corante na dentina com maior concentração em torno da luz do canal. Nota-se que no espécime do grupo II a imagem sugere presença de dentina esclerótica ou atubular (seta). Verifica-se em todos os grupos o adequado isolamento do cemento radicular propiciado pelo cianoacrilato de etila, impedindo a contaminação eventual do corante no sentido cemento-canal 

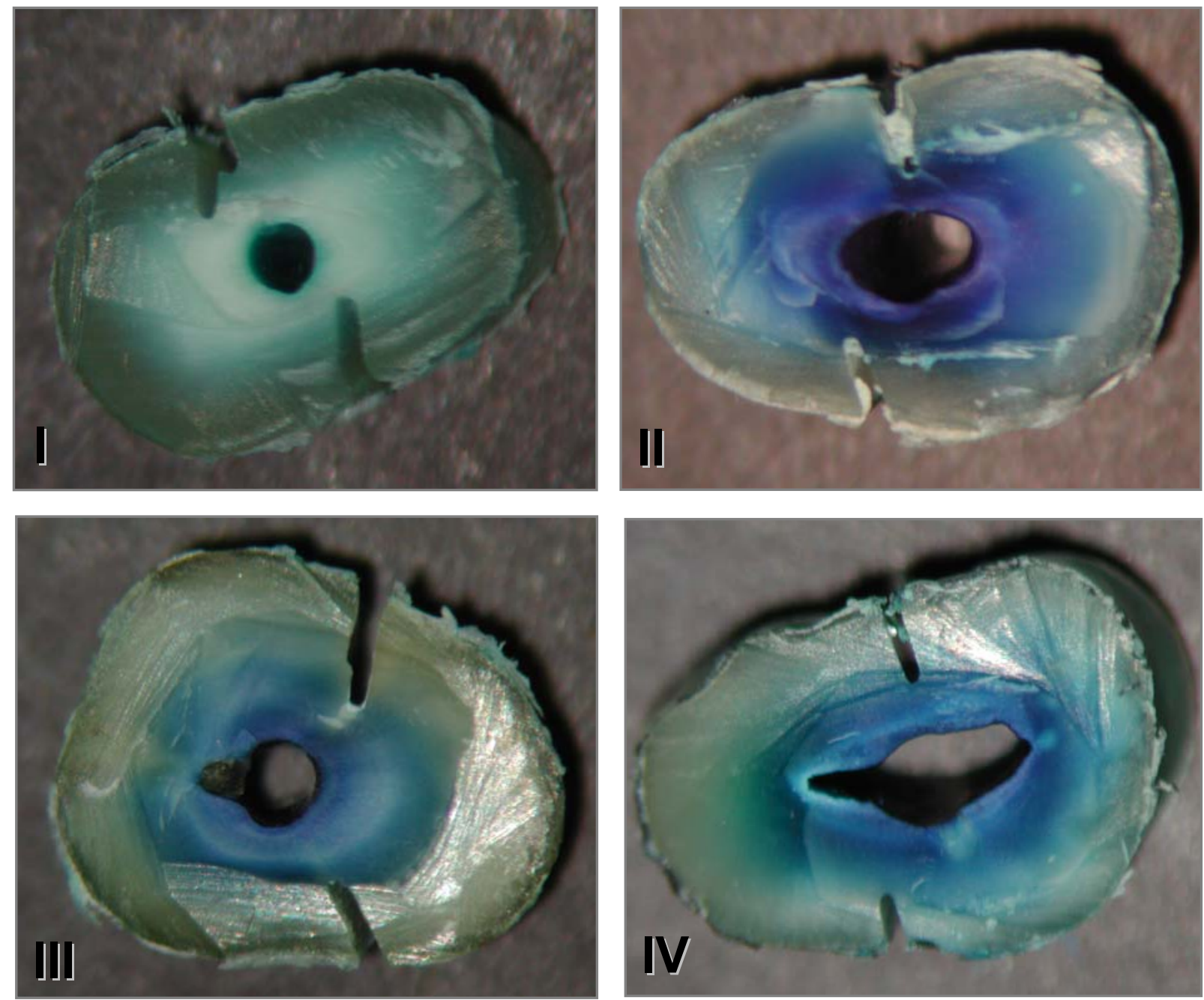

Figura 5.2 - Terços médios dos espécimes dos grupos submetidos ao estudo da permeabilidade dentinária - I (NaOCI); II (EDTA); III (EDTA-T); e, IV $\left(\mathrm{MTAD}^{\circledR}\right)$. Observa-se que em todos os espécimes houve grande penetração do corante na dentina com maior concentração em torno da luz do canal. Verifica-se em todos os grupos o adequado isolamento do cemento radicular propiciado pelo cianoacrilato de etila, impedindo a contaminação eventual do corante no sentido cemento-canal 

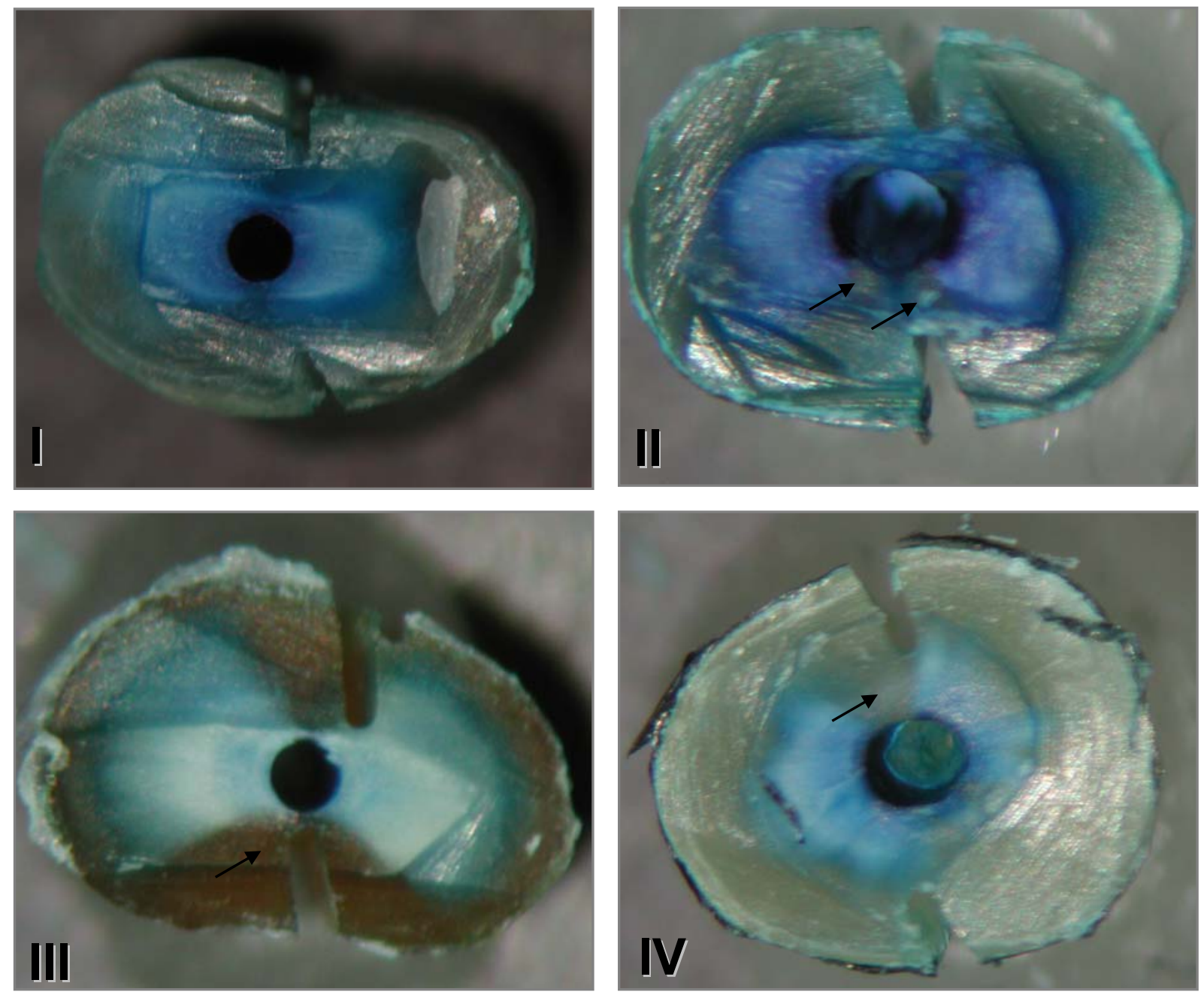

Figura 5.3 - Terços apicais dos espécimes dos grupos submetidos ao estudo da permeabilidade dentinária - I (NaOCl); II (EDTA); III (EDTA-T); e, IV $\left(M^{2}{ }^{\circledR}{ }^{\circledR}\right)$. Observa-se que em todos os espécimes houve maior penetração do corante em torno da luz do canal. Nota-se nos espécimes dos grupos II, III e IV que não houve penetração do corante em algumas áreas centrais, sugerindo-se presença de dentina esclerótica ou atubular (setas). Verifica-se em todos os grupos o adequado isolamento do cemento radicular propiciado pelo cianoacrilato de etila, impedindo a contaminação eventual do corante no sentido cemento-canal 


\subsection{Estudo da remoção do magma dentinário}

Os valores individuais originais dos escores obtidos nos grupos testados apresentam-se no Apêndice E. Os valores submetidos ao teste de normalidade mostram que a distribuição amostral não é normal (Apêndice F), optando-se então, pelo teste não-paramétrico de Kruskal-Wallis com nível de significância de $\alpha=0,05$. As médias e os resultados estatísticos dos escores da remoção da camada de magma para os grupos testados estão expressos na Tabela 5.3.

Tabela 5.3 - Médias dos escores de remoção do magma dentinário nos grupos avaliados e nos diferentes terços do canal radicular e níveis de significância de $5 \%$ entre si

\begin{tabular}{c|c|c|c|c}
\hline \hline Terços & cervical & médio & apical & TOTAL \\
\hline I & $3,00^{\mathrm{a} \Delta}$ & $2,83^{\mathrm{a} \Delta}$ & $2,94^{\mathrm{a} \Delta}$ & $2,92^{\Delta}$ \\
\hline II & $1,12^{\mathrm{a}}$ & $1,25^{\mathrm{a}}$ & $1,92^{\mathrm{b}}$ & $1,43^{\star}$ \\
\hline III & $1,17^{\mathrm{a}}$ & $1,22^{\mathrm{a}}$ & $1,39^{\mathrm{a}}$ & $1,26^{\star}$ \\
\hline IV & $1,00^{\mathrm{a}}$ & $1,08^{\mathrm{a}}$ & $1,25^{\mathrm{a}}$ & $1,11^{\star}$ \\
\hline TOTAL & $1,57^{\mathrm{a}}$ & $1,60^{\mathrm{a}}$ & $1,88^{\mathrm{a}}$ & 1,68 \\
\hline \hline
\end{tabular}

Letras iguais na mesma linha indicam grupos homogêneos estatisticamente não significantes $(p=0,05)$

Símbolos iguais na mesma coluna indicam grupos homogêneos estatisticamente não significantes $(p=0,05)$

Quando os grupos experimentais são comparados ao grupo controle há diferença estatística significante $(p<0,05)$. Os canais radiculares irrigados somente com $\mathrm{NaOCl}$ a $1 \%$ apresentam uma camada de magma cobrindo as paredes dentinárias, 
enquanto os canais irrigados com EDTA, EDTA-T ou MTAD ${ }^{\circledR}$ apresentam, na grande maioria das vezes, paredes livres de debris e túbulos dentinários desobstruídos. Comparando os grupos experimentais entre si, não há diferença estatística significante, ou seja, as soluções irrigadoras experimentais empregadas para irrigação final proporcionaram um grau similar de remoção do magma dentinário (Coluna Total da Tabela 5.3).

Quando nos diferentes terços do canal (cervical, médio e apical) são confrontados os grupos entre si, há diferenças estatísticas significantes, ou seja, as paredes dos canais apresentam distintos graus de limpeza após a irrigação final. Verifica-se que o $\mathrm{NaOCl}$ (grupo I) sempre mantém maior quantidade de magma dentinário com diferença significante em relação às demais substâncias irrigadoras em todos os terços. Porém, nos terços radiculares dos grupos II, III e IV, a quantidade de magma nas paredes dentinárias não apresenta diferenças estatisticamente significantes (Colunas da Tabela 5.3).

Quando a comparação é feita entre os terços cervical, médio e apical de cada grupo separadamente, isto é, para cada substância irrigadora, não são encontradas diferenças estatisticamente significantes nos grupos I, III e IV, ou seja, níveis semelhantes de remoção de debris foram encontrados. Somente o grupo II apresenta diferenças entre os terços cervical e médio em relação ao terço apical, sendo que este último apresenta paredes com maior quantidade de magma dentinário em relação aos demais terços (Linhas da Tabela 5.3). 
O teste de Kruskal-Wallis confirma as semelhanças e as diferenças da médias estatisticamente significantes e não significantes (Tabela 5.4). As Figuras 5.4 a 5.6 mostram eletromicrografias dos grupos avaliados segundo os terços do canal radicular. 
Tabela 5.4 - Valores absolutos das diferenças entre os postos médios dos tratamentos de acordo com os terços radiculares e níveis de significância estatística de Kruskal-Wallis segundo o método de Dunn ${ }_{5 \%}$

\begin{tabular}{|c|c|c|c|c|c|c|c|c|c|c|c|c|c|}
\hline \multirow{2}{*}{\multicolumn{2}{|c|}{$\begin{array}{l}\text { Grupos } \\
\text { e Terços } \\
\text { Grupos } \\
\text { Terços }\end{array}$}} & \multicolumn{3}{|c|}{ Grupo I } & \multicolumn{3}{|c|}{ Grupo II } & \multicolumn{3}{|c|}{ Grupo III } & \multicolumn{3}{|c|}{ Grupo IV } \\
\hline & & C & $\mathbf{M}$ & A & C & $\mathbf{M}$ & A & C & M & A & C & $\mathbf{M}$ & A \\
\hline \multirow{3}{*}{$\begin{array}{c}\text { Grupo } \\
\text { I }\end{array}$} & C & - & - & - & - & - & - & - & - & - & - & - & - \\
\hline & $\mathbf{M}$ & $11,58^{\mathrm{ns}}$ & - & - & - & - & - & - & - & - & - & - & - \\
\hline & A & $3,86^{\mathrm{ns}}$ & $7,72^{\mathrm{ns}}$ & - & - & - & - & - & - & - & - & - & - \\
\hline \multirow{3}{*}{ Grupo II } & C & $199,87^{s}$ & - & - & - & - & - & - & - & - & - & - & - \\
\hline & $\mathbf{M}$ & - & $169,67^{s}$ & - & $18,62^{\text {ns }}$ & - & - & - & - & - & - & - & - \\
\hline & A & - & - & $98,20^{s}$ & $101,67^{s}$ & $83,05^{s}$ & - & - & - & - & - & - & - \\
\hline \multirow{3}{*}{$\begin{array}{c}\text { Grupo } \\
\text { III }\end{array}$} & C & $193,67^{s}$ & - & - & $6,21^{\mathrm{ns}}$ & - & - & - & - & - & - & - & - \\
\hline & $\mathbf{M}$ & - & $173,80^{s}$ & - & - & $4,14^{\text {ns }}$ & - & $8,28^{\text {ns }}$ & - & - & - & - & - \\
\hline & A & - & - & $\begin{array}{c}167,18 \\
\text { s }\end{array}$ & - & - & $68,98^{\text {ns }}$ & $26,49^{\text {ns }}$ & $18,21^{\mathrm{ns}}$ & - & - & - & - \\
\hline \multirow{3}{*}{$\begin{array}{c}\text { Grupo } \\
\text { IV }\end{array}$} & C & $218,50^{s}$ & - & - & $18,62^{\text {ns }}$ & - & - & $24,83^{\text {ns }}$ & - & - & - & - & - \\
\hline & $\mathbf{M}$ & - & $194,14^{s}$ & - & - & $24,48^{\text {ns }}$ & - & - & $20,34^{\mathrm{ns}}$ & - & $12,77^{\text {ns }}$ & - & - \\
\hline & A & - & - & $177,39^{s}$ & - & - & $83,05^{s}$ & - & - & $14,07^{\text {ns }}$ & $37,25^{\mathrm{ns}}$ & $24,48^{\text {ns }}$ & - \\
\hline
\end{tabular}



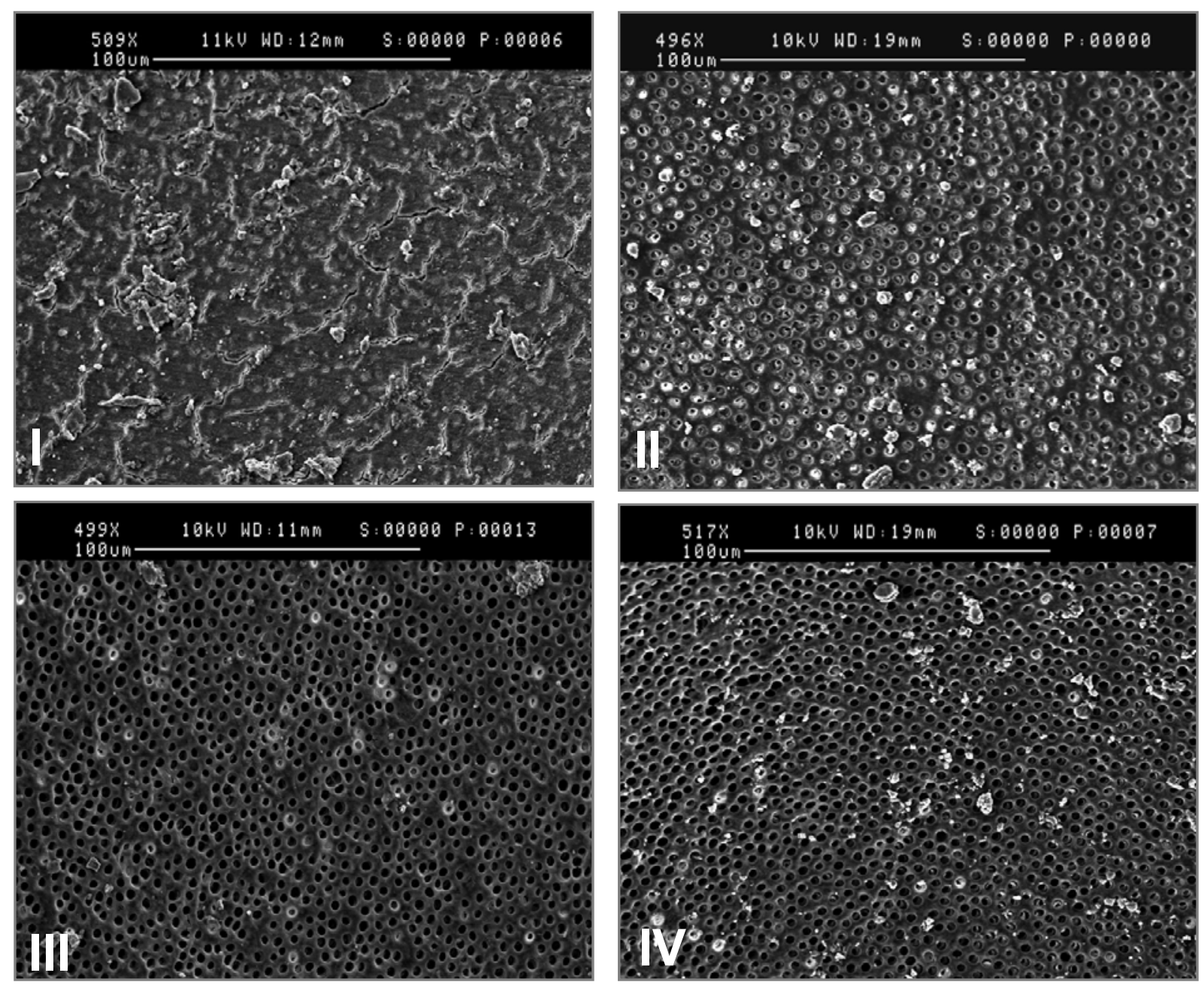

Figura 5.4 - Eletromicrografias dos terços cervicais dos espécimes dos grupos submetidos ao estudo da remoção do magma dentinário - I $(\mathrm{NaOCl})$ parede totalmente coberta por magma dentinário; II (EDTA) parede livre de magma dentinário e imagem sugestiva de presença de tampões de dentina (smear plug) no interior dos túbulos dentinários; III (EDTA-T) e IV (MTAD ${ }^{\circledR}$ ) paredes livres de magma dentinário e túbulos dentinários desobstruídos 

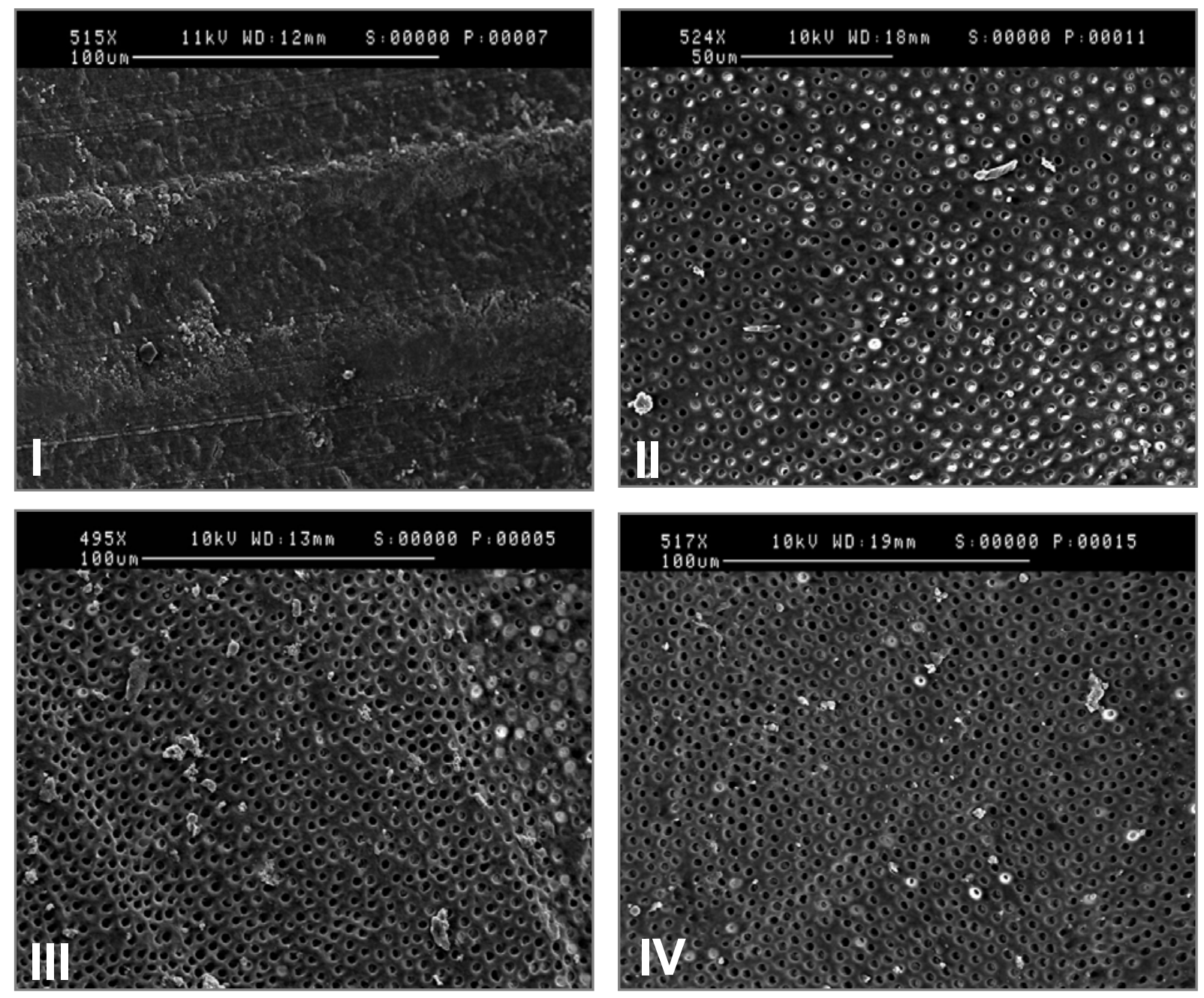

Figura 5.5 - Eletromicrografias dos terços médios dos espécimes dos grupos submetidos ao estudo da remoção do magma dentinário - I $(\mathrm{NaOCl})$ parede totalmente coberta por magma dentinário; II (EDTA), III (EDTA-T) e IV $\left(M_{T A D^{\circledR}}\right)$ paredes livres de magma dentinário e imagens sugestivas de presença de tampões de dentina (smear plug) no interior dos túbulos dentinários 

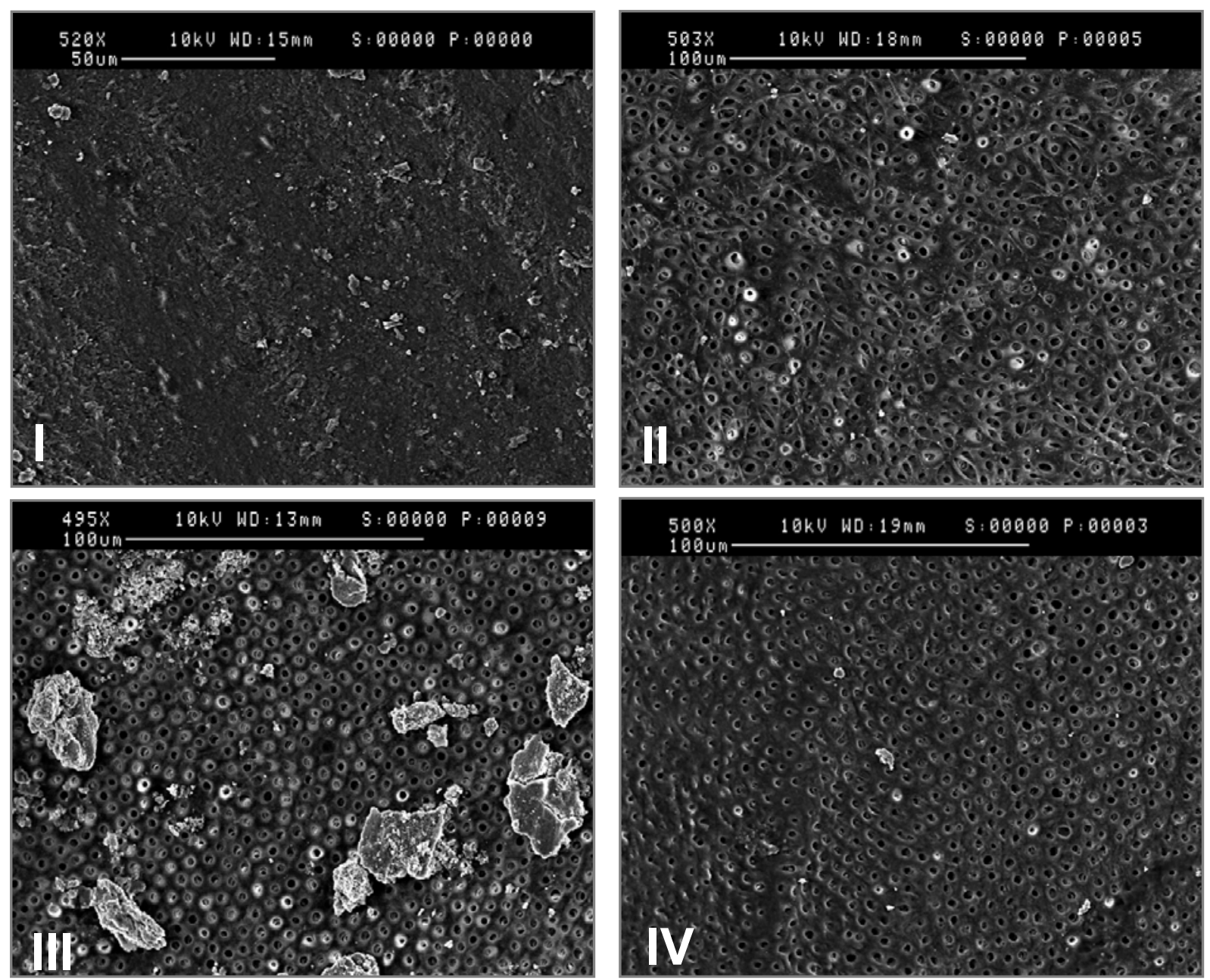

Figura 5.6 - Eletromicrografias dos terços apicais dos espécimes dos grupos submetidos ao estudo da remoção do magma dentinário - I (NaOCl) parede totalmente coberta por magma dentinário; II (EDTA), III (EDTA-T) e IV $\left(M_{T A D^{\circledR}}\right)$ paredes livre de magma dentinário e imagenes sugestivas de presença de tampões de dentina (smear plug) no interior dos túbulos dentinários 


\subsection{Inter-relações dos estudos da permeabilidade dentinária e da remoção do magma dentinário}

A inter-relação entre permeabilidade dentinária e remoção do magma dentinário está vinculada à comparações dos níveis de significância estatística, juntamente com a percepção visual gráfica e é finalizada pela aplicação do teste da correlação de Pearson utilizando os dados de cada um dos estudos realizados.

Quando os resultados estatísticos relacionados aos grupos ou substâncias testadas entre si nos estudos da permeabilidade dentinária e remoção do magma dentinário são confrontados nas mesmas condições ocorrem diferenças de interpretação, isto é não há coincidência do valor estatístico aferido entre os grupos em geral, os terços radiculares para cada substância irrigadora ou destas em cada um dos terços para ambos os estudos experimentais.

Nas comparações entre grupos II versus III, II versus IV e III versus IV não há diferença entre eles, tanto para o estudo da permeabilidade dentinária quanto para o estudo da remoção do magma dentinário. Em contrapartida, quando os grupos I versus II, I versus III e I versus IV são comparados, não ocorrem diferenças estatísticas para o estudo da permeabilidade, mas há para o teste da remoção do magma dentinário (Tabela 5.5).

Quando os terços radiculares são confrontados entre si com cada uma das substâncias irrigadoras, não há discrepância nos grupos I e IV, tanto para o aumento da permeabilidade dentinária quanto para a limpeza final da cavidade pulpar. Isto é, as 
diferenças não são estatisticamente significantes para ambos os estudos entre os terços do canal radicular.

Tabela 5.5 - Comparações dos níveis de significância estatística entre os estudos da permeabilidade dentinária e da remoção do magma dentinário para os grupos avaliados

\begin{tabular}{c|cc}
\hline ESTUDOS & $\begin{array}{c}\text { Permeabilidade } \\
\text { Dentinária }\end{array}$ & Magma Dentinário \\
I e III & ns & $\mathrm{s}$ \\
I e IV & ns & $\mathrm{s}$ \\
II e III & ns & $\mathrm{s}$ \\
II e IV & ns & $\mathrm{ns}$ \\
III e IV & ns & $\mathrm{ns}$ \\
\hline ns = não significante & $\mathrm{ns}$ & $\mathrm{ns}$ \\
\hline \hline
\end{tabular}

No grupo II, todos os terços apresentam infiltração semelhante ao corante azul de metileno, enquanto no estudo da remoção do magma dentinário, o terço apical apresenta paredes com debris com diferença estatisticamente significante em relação aos terços cervical e médio. Já no grupo III o terço apical apresenta menor permeabilidade da dentina quando comparado aos terços cervical e médio, sendo as diferenças significantes. Porém, as paredes dos canais apresentam aspecto semelhante quanto à limpeza da superfície em todos os terços cujas diferenças não são significantes (Tabela 5.6). 
Tabela 5.6 - Comparações dos níveis de significância estatística entre os estudos da permeabilidade dentinária e da remoção do magma dentinário para os terços de cada substância avaliada

\begin{tabular}{|c|c|c|c|}
\hline GRUPOS & $\begin{array}{c}\text { Terços do } \\
\text { Canal }\end{array}$ & $\begin{array}{c}\text { Permeabilidade } \\
\text { Dentinária }\end{array}$ & $\begin{array}{c}\text { Magma } \\
\text { Dentinário }\end{array}$ \\
\hline \multirow{3}{*}{ I } & C e M & ns & ns \\
\hline & C e A & ns & ns \\
\hline & M e A & ns & ns \\
\hline \multirow{3}{*}{ II } & $C$ e $M$ & ns & ns \\
\hline & $C$ e $A$ & ns & $s$ \\
\hline & M e A & ns & $\mathrm{s}$ \\
\hline \multirow{3}{*}{ III } & C e M & ns & ns \\
\hline & C e A & $\mathrm{s}$ & ns \\
\hline & Me A & $s$ & ns \\
\hline \multirow{3}{*}{ IV } & C e M & ns & ns \\
\hline & C e A & ns & ns \\
\hline & M e A & ns & ns \\
\hline
\end{tabular}

Quando as substâncias irrigadoras são confrontadas em cada terço radicular analisado, há diferenças nos resultados estatísticos. Nos três terços do canal (cervical, médio e apical) não há concordância dos resultados estatísticos da permeabilidade dentinária e da remoção do magma quando se compara o grupo controle (grupo I) aos grupos experimentais II, III e IV. Assim, não são identificadas diferenças quando 
comparados no estudo da permeabilidade dentinária, mas são encontradas no estudo da remoção do magma dentinário.

Quando se comparam os grupos experimentais II, III e IV entre si, em todos os terços radiculares, as interpretações estatísticas são idênticas para a permeabilidade dentinária e limpeza do magma dentinário, representados por semelhantes percentuais de penetração do corante e de qualidade e de ausência de magma dentinário (Tabela $5.7)$.

Para melhor visualização da inter-relação da permeabilidade dentinária e presença de magma dentinário, os valores em escores do estudo sobre a remoção do magma dentinário foram convertidos em percentuais (Figura 5.7). 
Tabela 5.7 - Comparações dos níveis de significância estatística entre os estudos da permeabilidade dentinária e da remoção do magma dentinário das substâncias avaliadas em cada terço

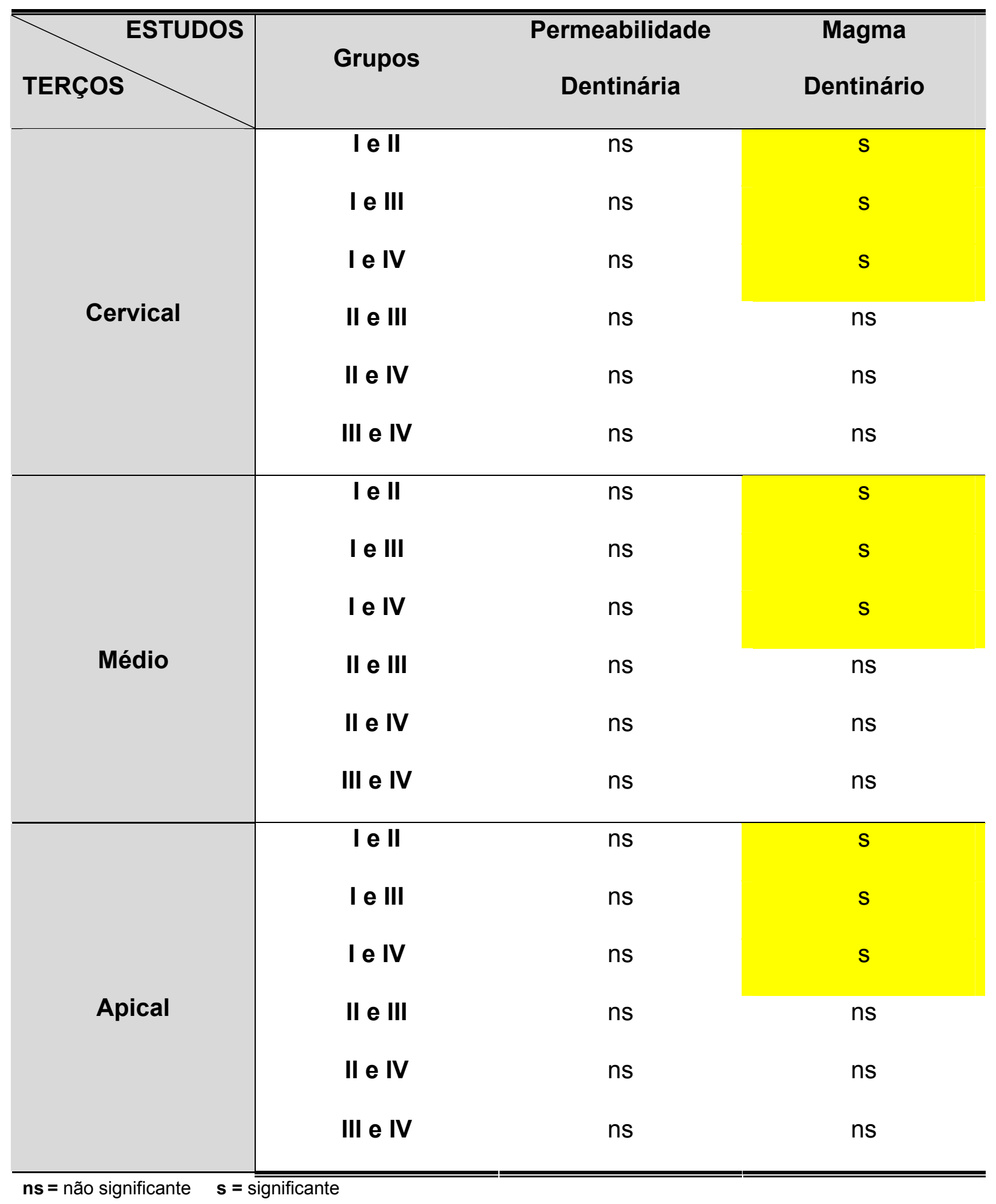



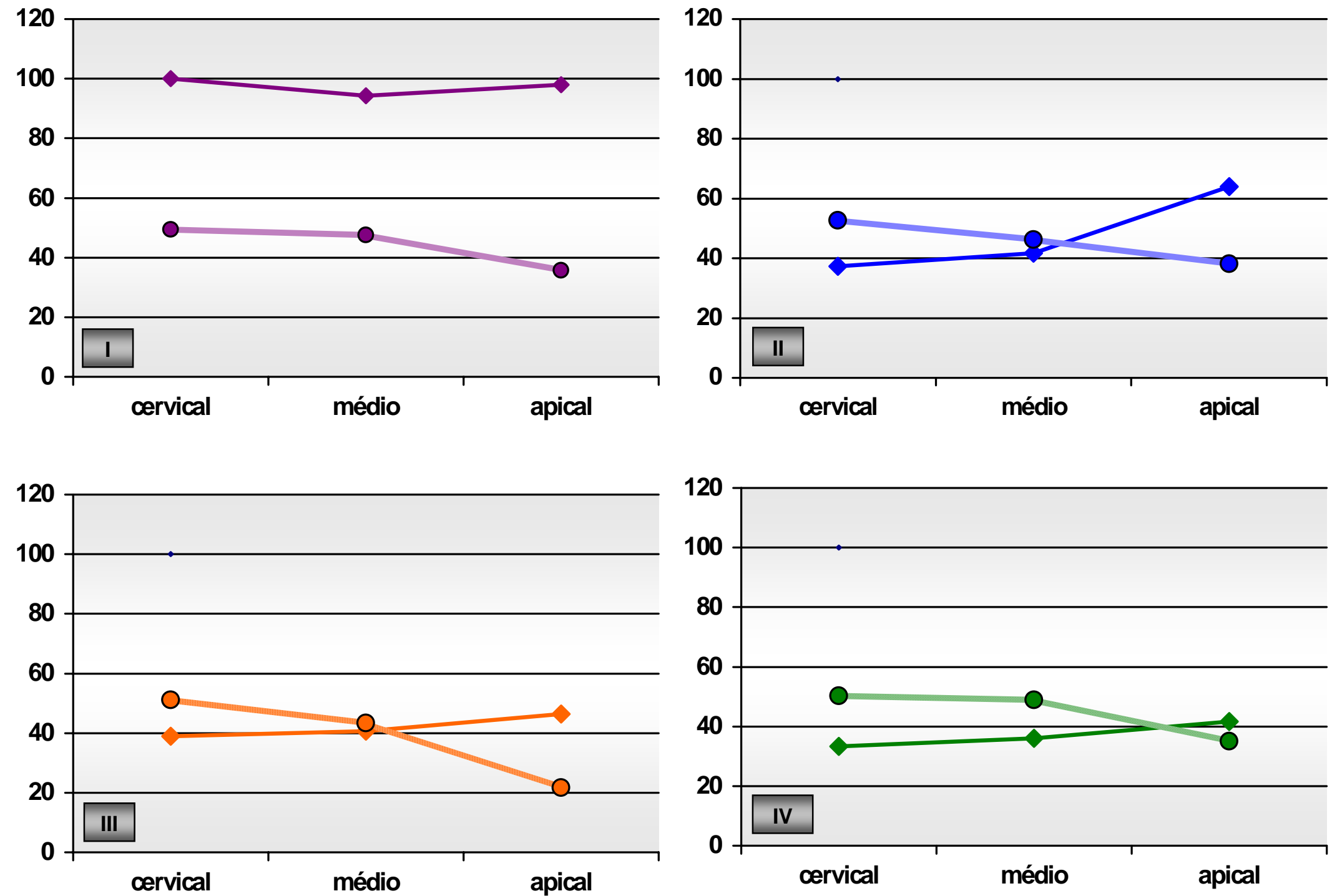

Figura 5.7 - Conversão dos resultados de permeabilidade dentinária $(\bullet)$ e remoção de magma dentinário $(\bullet)$ em porcentagens de ocorrência e sua correspondente relação segundo os terços radiculares em cada grupo experimental. 
Além das comparações dos níveis de significância estatística e gráficas, foi realizado o teste de correlação de Pearson para comparar a relação entre os estudos sobre a permeabilidade dentinária e remoção do magma dentinário. Verifica-se que a correlação é negativa para os terços e positiva para os resultados como um todo, sendo ambas as correlações médias não significantes (Tabela 5.8). Este resultado confirma que não há uniformidade de correlação como o comprovado anteriormente na comparação das significâncias estatísticas das diferenças entre grupos e terços, quer na infiltração do corante, quer na presença de magma dentinário. Os resultados podem ser melhor visualizados nas Figuras 5.8 e 5.9.

Tabela 5.8 - Correlação entre a infiltração e magma dentinário com nível de significância de $\alpha=0,05$

\begin{tabular}{c|ccccc}
\hline \hline & pares & $\mathbf{r}$-Pearson & $\mathbf{G L}$ & $\mathbf{( p )}$ & Signif. \\
\hline Terços & 12 & $-0,4249$ & 10 & 0,1684 & $\mathrm{~ns}$ \\
Todo & 4 & 0.4207 & 2 & 0,5793 & $\mathrm{~ns}$ \\
\hline \hline
\end{tabular}




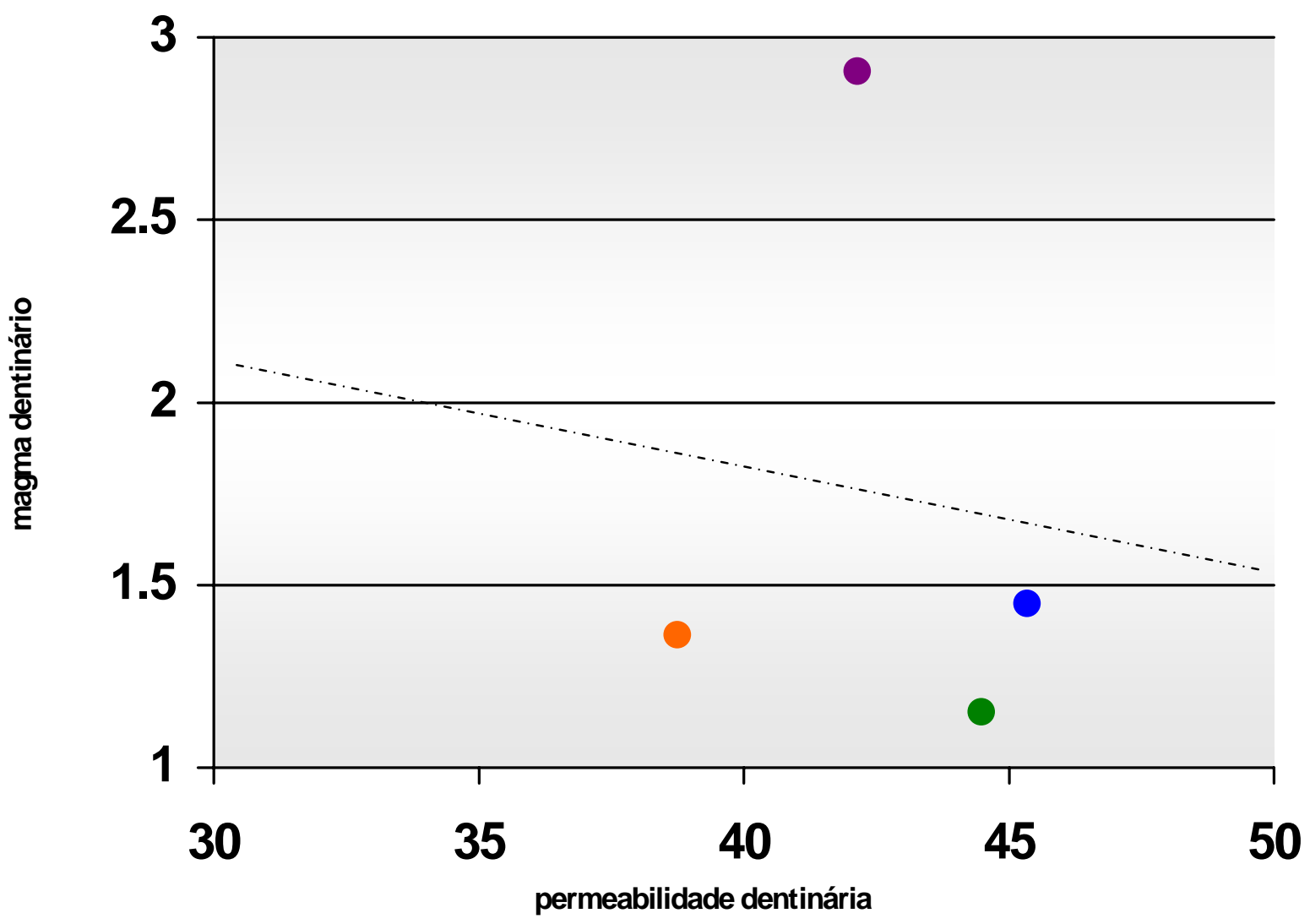

grupo I; $\quad$ grupo II; $\quad$ grupo III; $\quad$ grupo IV

Figura 5.8 - Coeficiente de correlação de Pearson para os grupos testados segundo as médias de permeabilidade dentinária e de magma dentinário 


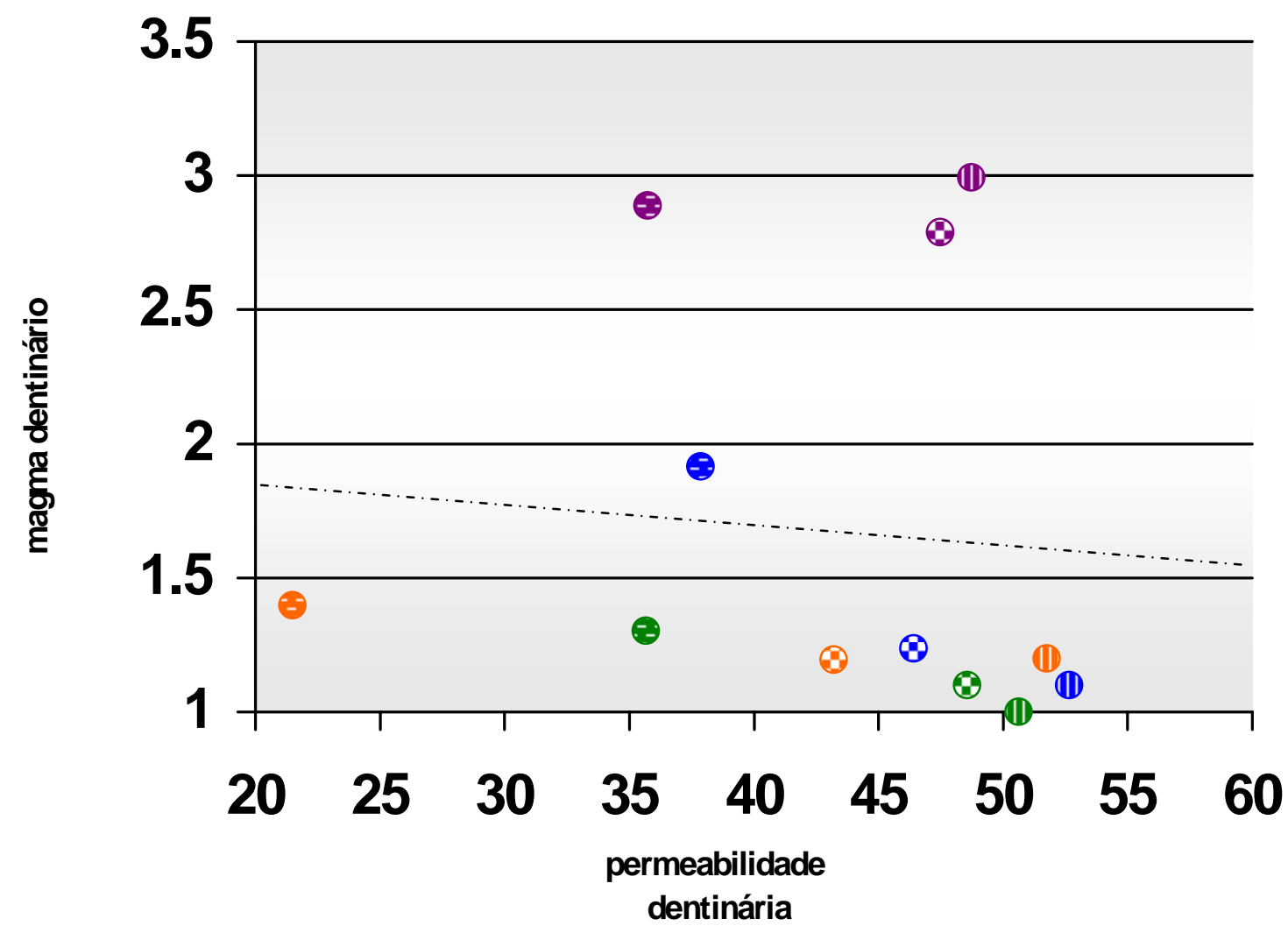

grupo I; $\quad$ grupo II; $\quad$ grupo III; $\quad$ grupo IV

(1) terço cervical;

(1) terço médio;

$\Theta$ terço apical

Figura 5.9 - Coeficiente de correlação de Pearson para os terços radiculares dos grupos testados segundo as médias de permeabilidade dentinária e de magma dentinário 


\section{DISCUSSÃO}

No contexto da terapia endodôntica, a fase de preparo do canal ocupa um papel de destaque, pois, além de ser a etapa que demanda mais tempo e esforço do profissional, é nela que o canal principal é modelado e o sistema endodôntico é submetido à limpeza e desinfecção. Esta condição é obtida por meio da ação de instrumentos e substâncias químicas específicas.

Durante as manobras de execução do preparo do canal deseja-se que ocorram alterações estruturais no sistema endodôntico. A permeabilidade da dentina deve ser aumentada, facilitando a ação em profundidade dos fármacos. Findo o PQC, uma irrigação-aspiração final deve ser realizada para remover os detritos depositados sobre as paredes da dentina. Esta manobra finaliza o preparo do sistema endodôntico para receber a medicação e a sua ulterior obturação.

No presente estudo, todos os canais foram instrumentados até o comprimento de trabalho com série de instrumentos rotatórios ProTaper (de S1 a F3). O número de usos recomendado pelo fabricante é de seis vezes, sendo os instrumentos então descartados. A associação creme de Endo-PTC e NaOCl a 1\% foi empregada como auxiliar do PQC. Esta associação tem ação lubrificante, o que facilita a ação do instrumento, aumenta a permeabilidade natural da dentina, libera oxigênio nascente, auxilia na descontaminação do sistema endodôntico, entre outras vantagens (ROBAZZA, 1973; PAIVA; ANTONIAZZI, 1973; MOURA, 1985; PROKOPOWITSCH; 
MOURA; MUENCH, 1989; PAIVA; ANTONIAZZI, 1993; LAGE-MARQUES; ANTONIAZZI, 2002).

O NaOCl, nas mais diferentes concentrações, é a solução auxiliar do preparo do canal mais utilizada, atuando exclusivamente em matéria orgânica, dissolvendo-a. Além de ser um excelente agente bactericida, aumenta a permeabilidade dentinária (ROBAZZA, 1973; GOLDMAN et al., 1982; PÉCORA, 1985; PÉCORA et al., 1993; SPANÓ et al., 2001; ESTRELA et al., 2002; CARDOSO DE MENEZES; ZANET; VALERA, 2003; HAAPASALO et al., 2005; MARENDING et al., 2007). O NaOCl ainda é mundialmente a solução de escolha para irrigação-aspiração final da cavidade pulpar. $\mathrm{O} \mathrm{NaOCl}$ a $1 \%$ foi aqui utilizado por apresentar baixa toxicidade e ainda assim, exercer suas propriedades químicas (UNIVERSIDADE DE SÃO PAULO, 2004; HAAPASALO et al., 2005; ZEHNDER, 2006). Além disso, a concentração de $\mathrm{NaOCl}$ ideal para uso em conjunto com o MTAD $^{\circledR}$ é de 1,3\% (TORABINEJAD et al., 2003a).

Posteriormente ao trabalho de McComb e Smith (1975), quando foi observada a presença de magma dentinário depositado nas paredes dos canais após seu preparo, a irrigação-aspiração com substâncias capazes de atuarem nos componentes inorgânicos do magma dentinário tornou-se uma condição imprescindível na busca do sucesso do tratamento endodôntico (LAGE-MARQUES; ANTONIAZZI, 2002; TORABINEJAD et al., 2002, 2003a, 2003b; HAAPASALO et al., 2005).

Ao se utilizar tanto $\mathrm{NaOCl}$, quanto solução salina ou água destilada como substância auxiliar do PQC, a formação e deposição do magma dentinário ocorre de maneira semelhante (BAKER et al., 1975; YANG; BAE, 2002; GUERISOLI et al., 2002; TORABINEJAD et al., 2003a; 2003b; CARDOSO DE MENESES; ZANET; VALERA, 2003; MELLO et al., 2007). Como a solução salina ou água destilada não são 
empregadas como substância auxiliar durante o PQC e nem como irrigante final do canal radicular, o $\mathrm{NaOCl}$ foi empregado no presente trabalho como grupo controle (TEIXEIRA; FELIPPE; FELIPPE, 2005; KHADEMI; YAZDIZADEH; FEIZIANFARD, 2006). Como citado acima, o $\mathrm{NaOCl}$ não atua em matéria inorgânica, fazendo-se necessária a complementação da irrigação final utilizando-se um irrigante específico com capacidade de ação na estrutura inorgânica do magma dentinário (GUERISOLI et al., 2002).

Após o PQC, os canais dos espécimes dos grupos experimentais foram irrigados com diferentes substâncias e concomitantemente aspirados para remover o magma dentinário.

O EDTA, o EDTA-T e o MTAD ${ }^{\circledR}$ foram selecionados por serem substâncias irrigadoras para limpeza final das paredes do canal radicular que atuam sobre os íons cálcio da dentina. Como o $\mathrm{MTAD}^{\circledR}$ é um produto novo, demanda pesquisas para avaliar suas propriedades. O protocolo utilizado para irrigação com EDTA e EDTA-T foi baseado em trabalhos na literatura que estabeleceram tanto o tempo quanto o volume da solução para irrigação (SCELZA et al., 2004; TEIXEIRA; FELIPPE; FELIPPE, 2005; MELLO et al., 2007). Para irrigação com MTAD ${ }^{\circledR}$ foi empregado o protocolo proposto por Torabinejad et al. (2003a), que é o mesmo adotado pelo fabricante.

A agulha de irrigação é um fator importante durante a irrigação final do canal e a profundidade que sua ponta alcança no interior do canal radicular pode influenciar na desinfecção do sistema de canais radiculares e também na qualidade da remoção do magma dentinário (GOLDMAN et al., 1976, 1981, 1982; TORABINEJAD et al., 2003a; SEDGLEY et al., 2005). O instrumento F3 da série ProTaper, último instrumento utilizado para o preparo do canal, possui um diâmetro de 0,30 mm em D1. O 
alargamento proporcionado pela sua ponta possibilitou que a agulha de irrigação de calibre 30 pudesse atuar facilmente a $2 \mathrm{~mm}$ do comprimento real de trabalho.

\subsection{Estudo da permeabilidade dentinária}

Inúmeros trabalhos têm sido desenvolvidos ao redor do tema permeabilidade ao longo dos anos, o que demonstra a sua importância dentro do contexto da terapia endodôntica (FISH, 1933; ROBAZZA, 1973; ROBAZZA; ANTONIAZZI, 1976; PASHLEY, 1984; MOURA, 1985; PROKOPOWITSCH; MOURA; MUENCH, 1989; PASCON; KANTOVITZ; PUPPIN-RONTANI, 2006). Há consenso entre os autores de que o aumento da permeabilidade é um fator de alta relevância para o tratamento endodôntico, pois permite tanto às soluções irrigadoras utilizadas durante o preparo do canal, quanto à medicação intracanal atuarem profundamente na dentina, quer dissolvendo tecido orgânico, quer contribuindo para a redução bacteriana (PASHLEY, 1984; PAIVA; ANTONIAZZI, 1993; LAGE-MARQUES; ANTONIAZZI, 2002; PASCON; KANTOVITZ; PUPPIN-RONTANI, 2006).

Primeiramente, observou-se a maneira que diferentes substâncias irrigadoras alteram a permeabilidade dentinária radicular. Não houve diferença estatística significante da porcentagem da área de penetração do corante entre todos os grupos avaliados. Apesar de acreditar-se que a irrigação-aspiração final com EDTA, EDTA-T ou $M T A D^{\circledR}$ aumentariam a permeabilidade dentinária em relação à irrigação-aspiração final com $\mathrm{NaOCl}$, o presente trabalho não comprova tal afirmação. Quando a dentina é 
imersa em corante após exposição a soluções de $\mathrm{NaOCl}$, não somente os túbulos ficam corados, mas também a dentina intertubular, comprovando a ação do $\mathrm{NaOCl}$ sobre a matéria orgânica e sobre a permeabilidade dentinária (MARENDING et al., 2007).

Outros autores também verificaram que o uso de $\mathrm{NaOCl}$ a $1 \%$ para irrigaçãoaspiração final afetou a permeabilidade da dentina radicular de forma semelhante ao EDTA e/ou ao ácido cítrico a 10\%, este último, componente do MTAD $^{\circledR}$ (PÉCORA, 1985; MOURA et al., 1988; RIBEIRO, 2001). Quando o EDTA a $15 \%$ e o $\mathrm{NaOCl}$ a $0,5 \%$ foram utilizados como coadjuvantes do PQC isoladamente, também permitiram graus similares de penetração do agente indicador (PÉCORA et al., 1993). Zuolo et al. (1987) tiveram resultados conflitantes, sendo que, dependendo da natureza do tensoativo adicionado à solução de EDTA, o mesmo permitia maior aumento da permeabilidade dentinária ou não, em relação ao grupo controle no qual o soro fisiológico foi empregado para irrigação final. Alguns autores observaram níveis inferiores de permeabilidade dentinária para o EDTA quando comparado à água, ao lauril dietilenoglicol sufonato éter de sódio, à água oxigenada e ao $\mathrm{NaOCl}$ (MARSHALL; MASSLER; DUTE, 1960; FRASER; LAWS, 1976; ROBAZZA; ANTONIAZZI, 1976). Em contrapartida, outros autores obtiveram maiores índices de permeabilidade dentinária quando utilizaram um agente descalcificante para irrigação-aspiração final do canal radicular em relação ao $\mathrm{NaOCl}$ (PROKOPOWITSCH; MOURA; MUENCH, 1989; FOGEL; PASHLEY, 1990; PÉCORA et al., 1993; GUIGNES; FAURE; MAURETTE, 1996).

$\mathrm{O} \mathrm{NaOCl}$ foi selecionado para o grupo controle por se tratar de uma substância que, comprovadamente, aumenta a permeabilidade dentinária, além de ser a solução mais utilizada como auxiliar da instrumentação de canais radiculares nas mais 
diferentes concentrações e também como irrigante final, atuando exclusivamente em matéria orgânica (ROBAZZA, 1973; PÉCORA, 1985, 1993; SPANÓ et al., 2001; ESTRELA et al., 2002; TORABINEJAD; SHABAHANG; BAHJRI, 2005; HAAPASALO et al., 2005; MARENDING et al., 2007).

A dentina é um tecido conjuntivo mineralizado, constituído basicamente por cerca de 50 a 70\% de material inorgânico, 18 a 30\% de parte orgânica e 12 a 20\% de água (RODE; PENNA; CAVALCANTI, 2000). O NaOCI dissolve a matéria orgânica da dentina por meio da reação de saponificação. Quando este degrada os lipídeos e os ácidos gordurosos, dá-se a formação de sabão e glicerol, que são facilmente eliminados pelo fluxo irrigante. Esta reação aumenta a permeabilidade dentinária (SPANÓ et al., 2001; ESTRELA et al., 2002).

O EDTA, o EDTA-T e o MTAD ${ }^{\circledR}$ foram utilizados para a irrigação-aspiração final dos grupos experimentais. Estes irrigantes atuam na porção inorgânica da parede da dentina e do magma, mais especificamente nos íons cálcio, auxiliando na remoção dos debris depositados nas paredes do canal. Os primeiros atuam pelo mecanismo físicoquímico da quelação e o último pela reação química ácido-base.

Quando os terços do canal radicular foram confrontados entre si com a mesma substância irrigadora, diferenças estatísticas foram encontradas. Embora os trabalhos na literatura mostrem que geralmente ocorrem diferenças de permeabilidade entre as diferentes regiões do canal radicular, isso não ocorreu nos grupos nos quais a irrigação foi realizada empregando-se $\mathrm{NaOCl}$, EDTA e $\mathrm{MTAD}^{\circledR}$. O tempo longo de irrigação e o calibre fino da agulha utilizada podem ter contribuído para homogeneização da permeabilidade alcançada nos diferentes terços do canal, já que a ponta da agulha alcançou as proximidades do forame apical (SEDGLEY et al., 2005). 
No grupo irrigado com EDTA-T houve diferença estatística significante quando se confrontaram os terços cervical e médio com o terço apical, sendo que o terço cervical apresentou maior penetração do corante quando comparado ao terço apical do canal radicular, assim como o terço médio apresentou maior infiltração do corante quando comparado ao terço apical. Outros autores também obtiveram maiores índices de permeabilidade dentinária nos terços cervical e às vezes médio e menores índices no terço apical, relacionando estes resultados ao maior diâmetro dos túbulos dentinários na região cervical do canal, que vai diminuindo à medida que se aproxima do ápice radicular, sendo que esta região também apresenta dentina mais esclerótica, o que dificulta a difusibilidade de substâncias (MARSHALL; MASSLER; DUTE, 1960; ROBAZZA, 1973; SELTZER; BENDER, 1975; ROBAZZA; ANTONIAZZI, 1976; FRASER; LAWS, 1976; WHITTAKER; KNEALE, 1979; PÉCORA, 1985; PASHLEY, 1984; MOURA, 1985; ZUOLO et al., 1987; GREMPEL; ANTONIAZZI; PAIVA, 1990; TAO; ANDERSON; PASHLEY, 1991; PÉCORA et al., 1993; FRÓIS, 1999; HARRÁN PONCE; CANALDA SAHLI; VILAR FERNANDEZ, 2001; RIBEIRO, 2001).

Variações inesperadas quanto ao índice de permeabilidade dentinária radicular podem ocorrer, sendo que alguns fatores interferem no fluxo de fluidos pela dentina como a presença ou ausência do tecido pulpar, a presença ou ausência de debris na superfície dos túbulos, doença periodontal prévia e, também, o grau de oclusão ou calcificação dos túbulos dentinários (FISH, 1933; PASHLEY; LINVINGSTON; GREENHILL, 1978; MJÖR, 1985; FRÓIS, 1999). Se durante um estudo, os dentes utilizados apresentam uma ou várias destas condições, variações podem ocorrer. Os dentes utilizados neste estudo foram extraídos por razões diversas, de pacientes entre 
18 e 50 anos. O fator idade também pode interferir no índice de permeabilidade natural dos dentes (GREMPEL; ANTONIAZZI; PAIVA, 1990).

A metodologia usada para avaliar a permeabilidade dentinária foi a injeção do corante azul de metileno no interior do canal principal. A utilização de corantes já foi empregada por outros autores e representa uma metodologia de simples reprodução (FISH, 1933; ANTONIAZZI; MJÖR; NYGAARD-ØSTBY, 1968; ROBAZZA, 1973; GOLDMAN et al., 1976; ROBAZZA; ANTONIAZZI, 1976; FRASER; LAWS, 1976; FOGEL; PASHLEY, 1990; ROBAZZA, 1991; TAO; ANDERSON; PASHLEY, 1991; FRÓIS, 1999; RALDI; LAGE-MARQUES, 2003; MARENDING et al., 2007). Para impedir que o corante penetrasse via cemento, os dentes foram primeiramente recobertos com cianoacrilato de etila (ROBAZZA, 1991). A utilização do clivador permitiu a obtenção de fragmentos limpos, sem perda de substância, que poderia ser causada pela ação de discos ou brocas (BOMBANA et al., 1993). Os fragmentos obtidos permitiram uma leitura da infiltração do corante no sentido transversal dirigindo-se para a profundidade da dentina (GOLDMAN et al., 1976; PÉCORA et al., 1993; FRÓIS, 1999; RALDI; LAGE-MARQUES, 2003). A mensuração da penetração do corante foi feita utilizandose o programa computadorizado Imagelab 2.3. Este programa foi selecionado por sua simplicidade de manipulação e acurácia, posto que, após a digitalização, o programa possui recursos que permitem adequar as imagens e delimitar exatamente a área corada para posterior cálculo do seu valor. 


\subsection{Estudo da remoção do magma dentinário}

Diante da necessidade da remoção do magma dentinário, diversas pesquisas vêm sendo desenvolvidas ao redor deste tema, quanto ao seu reconhecimento e as suas implicações no tratamento endodôntico (GOLDBERG; ABRAMOVICH, 1977; AKPATA; BLECHMAN, 1982; PASHLEY, 1984; MADER; BAUMGARTNER; PETERS, 1984, ØRSTAVIK; HAAPASALO, 1990; CZONSTKOWSKY; WILSON; HOLSTEIN, 1990; TORABINEJAD et al., 2002; MELLO, 2006). Outro objetivo deste estudo foi avaliar a atuação de diferentes substâncias irrigadoras sobre a remoção do magma dentinário durante a irrigação-aspiração. Os espécimes deste estudo foram divididos em grupos de dez raízes cada para testar quatro substâncias irrigadoras empregadas na irrigação-aspiração final do canal radicular. $\mathrm{O} \mathrm{NaOCl}$ foi utilizado por atuar sobre matéria orgânica do magma dentinário e como solução controle por ser a substância irrigadora mais utilizada mundialmente para irrigação final dos canais radiculares (CARDOSO DE MENEZES; ZANET; VALERA, 2005; TORABINEJAD; SHABAHANG; BAHJRI, 2005). O EDTA, o EDTA-T e o MTAD ${ }^{\circledR}$ foram selecionados por agirem sobre os componentes inorgânicos do magma dentinário, mais especificamente sobre os íons cálcio (NYGAARD-ØSTBY, 1957; GOLDMAN et al., 1981, 1982; TORABINEJAD et al., 2003b; HÜLSMANN; HECKENDORFF; LENNON, 2003).

Quando os grupos experimentais foram comparados ao grupo controle, houve diferença estatística significante. Os canais radiculares irrigados somente com $\mathrm{NaOCl}$ a 1\% apresentaram uma camada de magma cobrindo as paredes dentinárias, enquanto 
os canais irrigados com as substâncias experimentais descalcificantes apresentaram, na maioria das vezes, paredes livres de debris e túbulos dentinários desobstruídos. Este resultado era esperado, pois o $\mathrm{NaOCl}$ atua somente em matéria orgânica, que compõe pequena parte do magma dentinário (BAKER et al., 1975; McCOMB; SMITH, 1975; GOLDMAN et al., 1981, 1982; YAMADA et al., 1983; CENGIZ; AKTENER; PISKIN, 1990; GUERISOLI et al., 2002; CARDOSO DE MENEZES; ZANET; VALERA, 2003; TAY et al., 2006; YAMASHITA et al., 2003; TORABINEJAD et al., 2003a; KHADEMI; YAZDIZADEH; FEIZIANFARD, 2006). Quando os grupos experimentais foram comparados entre si, não houve diferença estatística significante, ou seja, as soluções irrigadoras experimentais empregadas para irrigação final do canal radicular tiveram eficácia similar na remoção do magma dentinário.

O EDTA age pelo fenômeno da quelação, que consiste no seqüestro de íons cálcio da dentina por meio de uma ligação de covalência, formando uma estrutura constituída por núcleos, que é chamada composto quelado. A eficiência do EDTA associado ao $\mathrm{NaOCl}$ na remoção do magma já foi comprovada em diversas pesquisas, sendo que esta combinação atua em ambos os componentes do magma dentinário (GOLDMAN et al., 1982; YAMADA et al., 1983; ØRSTAVIK: HAAPASALO, 1990; CENGIZ; AKTENER; PISKIN, 1990; YOSHIDA et al., 1995; SCELZA, 1998; SCELZA; ANTONIAZZI; SCELZA, 2000; YANG; BAE, 2002; CARDOSO DE MENEZES; ZANET; VALERA, 2003; YAMASHITA et al., 2003; TORABINJEAD et al., 2003a; 2003b; HÜLSMANN; HECKENDORFF; LENNON, 2003; TEIXEIRA; FELIPPE; FELIPPE, 2005; KHADEMI; YAZDIZADEH; FEIZIANFARD, 2006). 
O EDTA-T contém um tensoativo em sua formulação. Os detergentes, por serem tensoativos, auxiliam no processo de limpeza, diminuindo a tensão superficial, permitindo que a solução entre em contato mais rapidamente com as paredes do canal e penetre mais facilmente nos túbulos dentinários, além de auxiliar no processo de descontaminação do canal (PAIVA; ANTONIAZZI, 1973; PAIVA; ANTONIAZZI, 1993; LAGE-MARQUES; ANTONIAZZI, 2002; GUERISOLI et al., 2002; HÜLSMANN; HECKENDORFF; LENNON, 2003; SHABAHANG; TORABINEJAD, 2003). No presente estudo, a adição do detergente à fórmula original do EDTA não aumentou sua capacidade de remover o magma dentinário. Durante o tratamento endodôntico, o canal está preenchido com solução irrigante, a dentina encontra-se molhada e a tensão interfacial dos líquidos atuantes, segundo Zehnder (2006), desempenha um papel muito pequeno neste meio.

Existem poucos trabalhos comparando a eficiência destas duas formulações sobre a remoção do magma dentinário. Quanto ao poder de remoção de íons cálcio, o EDTA foi semelhante ao ácido cítrico (componente do $M T A D^{\circledR}$ ) e ambos superiores ao EDTA-T no tempo de 3 min (SCELZA; TEIXEIRA; SCELZA, 2003).

Diferentemente das duas soluções quelantes acima citadas, o MTAD ${ }^{\circledR}$ tem na sua fórmula o ácido cítrico a 4,5\%, que age sobre os íos cálcio pelo mecanismo da desmineralização, mais especificamente pela relação ácido-base, em que os íons hidrogênio do ácido cítrico se ligam aos íons hidroxila da dentina formando água e sal, sendo assim, eliminados pela sucção. Também a doxiciclina tem poder desmineralizante e possui comprovada ação sobre o magma dentinário (KRAUSE; LIEWEHR; HAHN, 2007). As tetraciclinas, incluindo a doxiciclina, ligam-se prontamente à dentina e são subseqüentemente liberadas sem perder sua atividade antibacteriana, 
propriedade denominada de substantividade. Tal propriedade cria um reservatório de agente antibacteriano, o qual é liberado da superfície dentinária de forma lenta. $\mathrm{O}$ tratamento prolongado com doxiciclina não facilita a mutação bacteriana que geraria microorganismos tetraciclina-resistentes (TUKUSUDA; GABLER, 1993; BARKHORDAR et al., 1997).

Torabinejad et al. (2003b) obtiveram paredes dentinárias mais limpas após irrigação com $\mathrm{MTAD}^{\circledR}$ em relação ao EDTA. García-Godoy et al. (2005) e Tay et al. (2006) não encontraram diferenças quanto à limpeza das paredes dentinárias após empregar MTAD $^{\circledR}$ ou EDTA para irrigação final. Já Scelza (1998) obteve melhores resultados quanto à limpeza das paredes do canal após irrigação final, com a associação $\mathrm{NaOCl}$ a 0,5\% e EDTA-T do que com $\mathrm{NaOCl}$ a 0,5\% associado ao ácido cítrico.

No que diz respeito ao poder de remoção de íons cálcio, o EDTA e o ácido cítrico foram semelhantes no tempo de 3 min (SCELZA; TEIXEIRA; SCELZA, 2003). Quanto à agressividade do $\mathrm{MTAD}^{\circledR}$ em relação à desmineralização da dentina, a literatura apresenta resultados controversos quando compara-o ao EDTA, sendo que alguns trabalhos mostram remoção dos íons cálcio da dentina pelo MTAD ${ }^{\circledR}$ sem causar danos estruturais a este tecido (MACHNICK et al., 2003), enquanto outros mostram que o MTAD $^{\circledR}$ desmineralizou mais a dentina do que o EDTA a 17\% (GARCíA-GODOY et al., 2005; TAY et al., 2006). Segundo Takeda et al. (1999) o ácido cítrico mesmo a uma concentração baixa de $6 \%$ foi mais agressivo do que o EDTA a $17 \%$ quanto à desmineralização da dentina.

Quando a comparação é feita entre os terços cervical, médio e apical de cada grupo separadamente, isto é para cada substância irrigadora, não são encontradas 
diferenças estatisticamente significantes nos grupos nos quais o $\mathrm{NaOCl}$, EDTA-T e $M T A D^{\circledR}$ foram empregados como irrigantes. Somente o grupo irrigado com EDTA apresenta diferenças entre os terços cervical e médio em relação ao terço apical, sendo que este apresenta paredes com maior quantidade de magma dentinário em relação aos demais terços. Outros autores também obtiveram paredes dentinárias mais limpas nos terços cervical e às vezes médio quando comparados ao terço apical (McCOMB; SMITH, 1975; ZINNG; SAKURA; MOURA, 1997; SCELZA, 1998; SCELZA; ANTONIAZZI; SCELZA, 2000). Estudos mais recentes têm mostrado todas as áreas do canal radicular com paredes livres de debris quando emprega-se um descalcificante (GUERISOLI et al., 2002; CARDOSO DE MENEZES; ZANET; VALERA, 2003; YAMASHITA et al., 2003; TEIXEIRA; FELIPPE; FELIPPE, 2005). Esses resultados homogêneos podem ter ocorrido pela utilização de agulhas de irrigação de fino calibre que introduzem as substâncias irrigadoras nas proximidades do comprimento de trabalho (SEDGLEY et al., 2005). Aliás, a importância do papel da agulha de irrigação na qualidade da limpeza foi abordada extensivamente nos trabalhos de Goldman et al. $(1976,1981,1982)$. No entanto, para que a agulha possa penetrar nas proximidades do comprimento de trabalho, existe a necessidade de um alargamento prévio desta região que permita sua atuação (KHADEMI; YAZDIZADEH; FEIZIANFARD, 2006). Todos os espécimes deste estudo foram alargados até o instrumento manual \# 35 no comprimento de trabalho, permitindo facilmente a ação da agulha de irrigação.

Do ponto de vista metodológico, foram utilizados dez espécimes para cada grupo, num total de quarenta espécimes. Estes quarenta dentes tiveram suas coroas removidas e foram primeiramente clivados no sentido transveral para análise da permeabilidade dentinária e então novamente clivados no sentido longitudinal, para 
análise da superfície dentinária em MEV. Durante esta segunda clivagem, alguns espécimes foram perdidos, o que resultou num número desigual de espécimes para cada grupo.

A MEV é o meio mais utilizado para análise em trabalhos sobre limpeza das paredes do canal radicular (McCOMB; SMITH, 1975; BAKER et al., 1975; GOLDBERG; ABRAMOVICH, 1977; PASHLEY; LIVINGSTON, 1978; PASHLEY et al., 1978; GOLDMAN et al., 1981, 1982; YAMADA et al., 1983; MADER; BAUMGARTNER; PETERS, 1984; ØRSTAVIK; HAAPASALO, 1990; CENGIZ; AKTENER; PISKIN, 1990; FOGEL; PASHLEY, 1990; BARKHORDAR et al., 1997; ZINNG; SAKURA; MOURA, 1997; TAKEDA et al., 1999; SCELZA; ANTONIAZZI; SCELZA, 2000; TORABINEJAD et al., 2002; YANG; BAE, 2002; GUERISOLI et al., 2002; CARDOSO DE MENEZES; ZANET; RALDI; LAGE-MARQUES, 2003; VALERA, 2003; YAMASHITA et al., 2003; TORABINEJAD et al., 2003a, 2003b; SCELZA; PIERRO; SCELZA, 2004; TEIXEIRA; FELIPPE; FELIPPE, 2005; TAY et al., 2006; KHADEMI; YAZDIZADEH; FEIZIANFARD, 2006; MELLO et al., 2007). As imagens obtidas em MEV foram examinadas por três diferentes avaliadores que utilizaram-se de escores para qualificar as imagens quanto à presença de magma dentinário. Esta metodologia de avaliação já foi utilizada em outros trabalhos do gênero e trata-se de um meio eficaz para ver a superfície dentinária e qualificar a limpeza obtida com as substâncias irrigadoras utilizadas (BAKER et al., 1975; CENGIZ; AKTENER; PISKIN, 1990; TAKEDA et al., 1999; GUERISOLI et al., 2002; CARDOSO DE MENEZES; ZANET; VALERA, 2003; YAMASHITA et al., 2003; TORABINEJAD et al., 2003a; 2003b; TEIXEIRA; FELIPPE; FELIPPE, 2005; KHADEMI; YAZDIZADEH; FEIZIANFARD, 2006; MELLO et al., 2007). 


\subsection{Inter-relação entre permeabilidade dentinária e remoção do magma dentinário}

A literatura deixa claro que a remoção do magma é aconselhável e que a ação conjunta do $\mathrm{NaOCl}$ e uma substância quelante ou desmineralizante é capaz de remover esta sujidade formada pela ação dos instrumentos (GOLDMAN et al., 1982; YAMADA et al., 1983; ØRSTAVIK: HAAPASALO, 1990; CENGIZ; AKTENER; PISKIN, 1990; YOSHIDA et al., 1995; GUIGNES; FAURE; MAURETTE, 1996; SCELZA, 1998; SCELZA; ANTONIAZZI; SCELZA, 2000; YANG; BAE, 2002; CARDOSO DE MENEZES; ZANET; VALERA, 2003; YAMASHITA et al., 2003; TORABINJEAD et al., 2003b; HÜLSMANN; HECKENDORFF; LENNON, 2003; TEIXEIRA, FELIPPE; FELIPPE, 2005; MELLO et al., 2007).

Alguns autores afirmam que a presença do magma dentinário tem grande influência na permeabilidade dentinária, uma vez que as substâncias se difundem por meio da dentina com mais facilidade quando a área de difusão é maior. A área disponível para difusão na dentina é determinada pela densidade dos túbulos dentinários, e quanto maior o número de túbulos expostos, maior o número de substâncias que podem difundir-se com mais facilidade (PASHLEY; MICHELICH; KEHL, 1981; PASHLEY, 1984; DIPPEL; BORGGREVEN; HOPPENBROUWERS, 1984). Na maioria dos estudos relacionando magma dentinário e permeabilidade dentinária, o magma foi criado pela ação de brocas ou outros instrumentos em alta ou baixa rotação (PASHLEY; LIVINGSTON, 1978; PASHLEY; MICHELICH; KEHL, 1981; DIPPEL; BORGGREVEN; HOPPENBROWERS, 1984). O magma criado durante a 
instrumentação do canal realizado com limas pode ser bem diferente daquele criado por brocas, que aquecem o tecido durante sua ação podendo derreter a dentina que irá impregnar ou aderir mais fortemente à parede dentinária (FOGEL; PASHLEY, 1990; CZONSTKOWSKY; WILSON; HOLSTEIN, 1990; TAO; ANDERSON; PASHLEY, 1991).

Entretanto, outros autores acreditam que o magma dentinário produzido durante o PQC altera muito pouco a permeabilidade dentinária (TAO; ANDERSON; PASHLEY, 1991). A instrumentação da dentina radicular resulta em diminuição da condutância hidráulica de um corante de 25 a 49\%, enquanto a condutância hidráulica da coroa após uso de brocas diminui entre 70 a 90\%. A redução superior da condutância hidráulica na coroa ocorre, provavelmente, devido ao aumento de calor provocado pelas brocas, mesmo sob refrigeração (FOGEL; PASHLEY, 1990).

A partir dos resultados obtidos nas duas avaliações deste estudo, foi realizada uma correlação entre os resultados para analisar a influência da remoção do magma dentinário sobre a permeabilidade dentinária.

Nas comparações entre EDTA versus EDTA-T, EDTA versus MTAD ${ }^{\circledR}$ e EDTA-T versus $M T A D^{\circledR}$, não houve diferença estatística tanto para o estudo da permeabilidade dentinária quanto para o estudo da remoção do magma dentinário, ou seja, o emprego de quelante ou desmineralizante foi fundamental para remover o magma dentinário e esta condição química não interferiu na permeabilidade da dentina.

Quando a irrigação final com $\mathrm{NaOCl}$ versus EDTA, $\mathrm{NaOCl}$ versus EDTA-T e $\mathrm{NaOCl}$ versus $\mathrm{MTAD}^{\circledR}$ foi comparada, não houve diferença estatística para o estudo da permeabilidade, mas ocorreu para o estudo da remoção do magma dentinário, ou seja, o uso de substância quelante ou desmineralizante não interferiu na permeabilidade dentinária, mas seu emprego foi fundamental para remover o magma dentinário. A 
presença ou ausência do magma dentinário não alterou os resultados da permeabilidade dentinária nos grupos testados.

Ao olhar-se para uma parede dentinária coberta de magma pode-se pensar que este é impermeável. No entanto, solutos isotópicos de vários tamanhos moleculares podem facilmente penetrar no magma dentinário, sendo que solutos com tamanho molecular menor penetram mais facilmente (PASHLEY; LIVINGSTON, 1978). O efeito do magma dentinário na permeabilidade dentinária não é causado primariamente pelo grau de cobertura dos túbulos dentinários, mas principalmente pelo grau de obstrução dos túbulos (PASHLEY et al., 1978; DIPPEL; BORGGREVEN; HOPPENBROUWERS, 1984). Quando a irrigação-aspiração final com uma substância quelante ou desmineralizante é realizada, pode somente remover a porção superficial do complexo smear layer/smear plug, não resultando em alteração da permeabilidade dentinária (TAO; ANDERSON; PASHLEY, 1991; GALVAN et al., 1994). Outra explicação seria que o irrigante usado para remover o magma dentinário pode produzir a precipitação de fosfato de cálcio no interior dos túbulos, dificultando a difusão de fluidos por meio da dentina (GUTIÉRREZ; GARCÍA, 1968; GALVAN et al., 1994).

O magma dentinário pode oferecer resistência à penetração de solutos, mas não impede o fluxo dos mesmos (PASHLEY; MICHELICH; KEHL, 1981). Fogel e Pashley (1990) constataram que o fluxo do corante utilizado continuou na presença de magma, porém, em menor velocidade. Possivelmente, o tempo de 48 h utilizado neste estudo tenha sido suficiente para o azul de metileno vencer a barreira representada pela smear layer e também pelo smear plug e difundir-se através da dentina, formando, desta forma, grupos homogêneos. Ørstavik e Haapasalo (1990) realizaram estudo semelhante, porém com diferentes medicações intracanal e verificaram que a presença 
do magma dentinário retardou, mas não impediu a penetrabilidade dos medicamentos. Raldi e Lage-Marques (2003) encontraram diferenças de penetração de corante associado à medicação intracanal nos terços cervical e médio de canais irrigados com EDTA-T e água destilada, porém, não encontraram diferença de penetração desta associação no terço apical dos canais dos diferentes grupos. As diferenças ocorridas nos terços cervical e médio podem dar-se devido ao fato da água destilada não possuir nenhuma ação nos componentes da dentina.

A presença do magma dentinário restringe a área disponível para que moléculas de diferentes tamanhos penetrem na dentina adjacente. No entanto, o magma dentinário foi permeável à albumina, uma molécula relativamente grande. A capacidade de uma substância permear a dentina também é dependente do tamanho da molécula. Moléculas pequenas, como as da água, por exemplo, permeam esta barreira formada pelo magma mais facilmente do que substâncias com moléculas maiores (PASHLEY; LIVINGSTON, 1978). É provavel que inflamações pulpares resultem de contaminação de dentina sadia por placa bacteriana pela penetração de produtos bacterianos através de magma dentinário depositado sobre a superfície da dentina (BERGENHOLTZ, 1977). Desta forma, fica claro que, apesar da presença do magma dentinário, a dentina é permeável a fluidos. A presença do magma dentinário pode retardar, mas não abole a ação de determinados medicamentos e fluidos ao longo dos túbulos dentinários (ØRSTAVIK; HAAPASALO, 1990).

Assim sendo, a irrigação final com um agente quelante ou desmineralizante pode não causar alteração na permeabilidade dentinária, como ocorreu quando comparou-se irrigação com $\mathrm{NaOCl}$ e EDTA, $\mathrm{NaOCl}$ e EDTA-T e $\mathrm{NaOCl}$ e MTAD ${ }^{\circledR}$. Outros autores também mostraram que a permeabilidade dentinária não é aumentada com a utilização 
de um agente descalcificante (ROBAZZA; ANTONIAZZI, 1976; MOURA et al., 1988; PROKOPOWISTCH; MOURA; MUENCH, 1989; TAO; ANDERSON; PASHLEY, 1991). Shabahang e Torabinejad (2003) não obtiveram desinfecção superior do sistema de canais radiculares após remoção do magma dentinário com EDTA a 17\% e irrigação final com $\mathrm{NaOCl}$ comparativamente aos espécimes nos quais o magma não foi removido. Os autores acreditam que a remoção do magma possa ter sido superficial dificultando a difusão do $\mathrm{NaOCl}$ no tecido dentinário ou até mesmo pela ineficiência do $\mathrm{NaOCl}$ em combater todas as bactérias. Diferentemente, Guignes, Faure e Maurette (1996) empregaram o EDTA para irrigação final do canal radicular e verificaram que quanto maior a quantidade do magma dentinário presente nas paredes dos canais radiculares, menor a permeabilidade dentinária, concluindo que o emprego do EDTA induz a um aumento considerável na permeabilidade radicular.

Apesar do grupo A ter apresentado paredes dentinárias cobertas de magma dentinário, esta camada não interferiu na sua permeabilidade dentinária. A instrumentação da dentina resulta em diminuição da condutância hidráulica em aproximadamente 50\% e a aplicação de $\mathrm{NaOCl}$ não afeta nem a condutância hidráulica do magma dentinário endodôntico nem seu aspecto quando observado sob MEV (FOGEL; PASHLEY, 1990).

Como as soluções de $\mathrm{NaOCl}$ não atuam em matéria inorgânica, não são capazes de remover a porção mineral do magma dentinário, que representa a maioria da sua massa (GOLDMAN et al., 1981; PAIVA; ANTONIAZZI, 1993; RODE; PENNA; CAVALCANTI, 2000). A dentina, no entanto, é composta de 18 a 30\% de parte orgânica e o $\mathrm{NaOCl}$ atua especificamente no componente orgânico, solubilizando o tecido. Esta ação solvente é devida à presença de ácido hipocloroso na solução, do fluxo durante o 
ato da irrigação e da superfície de contato (SPANÓ et al., 2001; UNIVERSIDADE DE SÃO PAULO, 2004). A solubilização do tecido explica porque a permeabilidade da dentina é aumentada quando o canal radicular é irrigado com soluções de $\mathrm{NaOCl}$, apesar do mesmo não remover a maioria dos componentes do magma quando comparado à água. Mais uma vez se faz clara a importância da associação de soluções irrigantes complementando a ação uma da outra e otimizando a remoção do magma dentinário (GOLDMAN et al., 1982; PÉCORA et al., 1993; SCELZA; ANTONIAZZI; SCELZA, 2000; PASCON; KANTOVITZ; PUPPIN-RONTANI, 2006). A concentração do $\mathrm{NaOCl}$ utilizada neste estudo foi de $1 \%$ por apresentar toxicidade relativamente baixa e bom poder antimicrobiano (ESTRELA et al., 2002; HAAPASALO et al., 2005). Além disso, a melhor concentração de $\mathrm{NaOCl}$ a ser utilizada em associação com o MTAD ${ }^{\circledR}$ é de 1,3\% (TORABINEJAD et al., 2003a), concentração bastante próxima à da solução de $\mathrm{NaOCl}$ empregada neste estudo.

As substâncias irrigadoras experimentais apresentaram, no geral, um comportamento semelhante entre si, tanto para o teste da permeabilidade dentinária, quanto para o teste de remoção do magma dentinário. O MTAD ${ }^{\circledR}$ apresenta em sua composição a doxiciclina, um antibiótico de largo espectro. Estudos in vitro têm demonstrado que a irrigação com tal substância é efetiva contra Enterococcus faecalis num espaço curto de tempo (SHABAHANG; TORABINEJAD, 2003; PORTENIER et al., 2006). Porém, não é rara a resistência de bactérias presentes em infecções endodônticas à tetraciclina (ROSSI-FEDELE; ROBERTS, 2007). O uso generalizado de antibióticos no lugar de antissépticos, tais como $\mathrm{NaOCl}$ ou clorexidina, parece inadvertido, já que os mesmos foram densenvolvidos para uso sistêmico ao invés de 
tópico (ZEHNDER, 2006). Como este irrigante teve um comportamento semelhante aos outros utilizados para a permeabilidade dentinária e também para a remoção do magma dentinário quando comparado aos outros agentes descalcificantes, talvez seja mais prudente empregá-los ao invés do MTAD ${ }^{\circledR}$.

Assim, como não houve uma relação direta em ambos os estudos para as substâncias irrigadoras, também não houve relação direta entre os terços do canal.

A metodologia de avaliação permitiu avaliar tanto as alterações na permeabilidade dentinária quanto a capacidade de remoção do magma dentinário de quatro diferentes irrigantes utilizando-se do mesmo grupo de espécimes. Esta metodologia foi utilizada pela primeira vez e os resultados estatísticos foram então confrontados. Um estudo piloto foi realizado para verificar a hipótese de que o corante azul de metileno não interfere na avaliação da superfície dentinária sob MEV e não foi identificada nenhuma alteração que inviabilizasse o estudo. Goldberg e Abramovich (1977) já apontavam a importância da utilização do mesmo espécime para efeitos comparativos mais fiéis.

\subsection{Considerações finais}

Embora o presente estudo mostre que a presença do magma dentinário não interfere na permeabilidade dentinária radicular, do ponto de vista clínico, ainda é necessário continuar pesquisando, já que a presença do magma dentinário pode 
interferir de outras formas no sucesso do tratamento endodôntico. No que concerne às associações e misturas de substâncias irrigadoras, outras alternativas ainda podem e devem ser investigadas, porém a necessidade de substâncias que atuem em todos os componentes da dentina é, sem dúvida, necessária. 


\section{CONCLUSÕES}

Diante do resultados in vitro obtidos conclui-se que:

1. as substâncias irrigadoras utilizadas tiveram efeito semelhante sobre a permeabilidade dentinária, independente do emprego de substâncias irrigadoras descalcificantes;

2. houve tendência dos terços cervical e médio apresentarem permeabilidade dentinária superior em relação ao terço apical apenas quando foram utilizados o EDTA e o MTAD;

3. o magma dentinário foi eficientemente removido por meio da irrigação final do canal radicular com as substâncias descalcificantes, o que não ocorreu com a irrigação somente de $\mathrm{NaOCl}$;

4. os três terços do canal radicular apresentaram o mesmo grau de limpeza das paredes da dentina, exceto para o EDTA-T, cujo terço apical mostrou maior quantidade de magma quando comparado às outras substâncias utilizadas;

5. a inter-relação da permeabilidade dentinária com o magma dentinário mostrou valores com tendência inversa sem, contudo, serem uniformes de acordo com os resultados estatísticos como um todo e para os terços radiculares;

6. a análise conjunta da permeabilidade dentinária e da remoção do magma dentinário mostrou-se viável nos mesmos espécimes radiculares, com 
aplicação inicial do corante seguido de fragmentação da raiz e processamento para MEV. 


\section{REFERÊNCIAS ${ }^{1}$}

Akpata ES, Blechman $\mathrm{H}$. Bacterial invasion of pulpal dentin wall in vitro. J Dent Res 1982;61(2):435-8.

Antoniazzi JH, Mjör IA, Nygaard-Østby B. Assessment of the sealing properties of root filling materials. Odontol Tidskr 1968;76(3):261-76.

Baker NA, Eleazer PD, Auerbach RE, Seltzer S. Scanning electron microscopic study of the efficacy of various irrigating solutions. J Endod 1975;1(4):127-35.

Barkhordar RA, Watanabe LG, Marshall GW, Hussain MZ. Removal of intracanal smear by doxycycline in vitro. Oral Surg Oral Med Oral Pathol Oral Radiol Endod 1997;84(4):420-3.

Bergenholtz G. Effect of bacterial products on inflammatory reactions in the dental pulp. Scand J Dent Res 1977;85(2):122-9.

Bombana AC, Zinet MPA, Antoniazzi JH. Avaliação do ponto de vista macroscópico da permanência de resíduos de hidróxido de cálcio após seu uso como medicação intracanal. In: Anais da $10^{\mathrm{a}}$. Reunião Anual da Sociedade Brasileira de Pesquisa Odontológica. Águas de São Pedro, 8-11 set. 1993. Águas de São Pedro: SBPqO, 1993. p. 70.

Cardoso de Menezes ACS, Zanet CG, Valera MC. Smear layer removal capacity of disinfectant solutions used with and without EDTA for the irrigation of canals: a SEM study. Pesqui Odontol Bras 2003;17(4):349-55.

Cengiz T, Aktener BO, Piskin B. Effect of dentinal tubule orientation on the removal of smear layer by root canal irrigants. A scanning electron microscopic study. Int Endod J 1990;23(3):163-71.

Cohen S, Stewart GG, Laster LL. The effects of acids, alkalies, and chelating agents on dentine permeability. Oral Surg Oral Med Oral Pathol 1970;29(4):631-4.

Czonstowsky M, Wilson EG, Holstein FA. The smear layer in Endodontics. Dent Clin North Am 1990;34(1):13-25.

\footnotetext{
${ }^{1}$ De acordo com estilo Vancouver. Abreviatura de periódicos segundo base de dados MEDLINE.
} 
Dippel HW, Borggreven JMPM, Hoppenbrouwers PMM. Morphology and permeability of the dental smear layer. J Prosthet Dent 1984;52(5):657-62.

Estrela C, Estrela CRA, Barbin EL, Spanó JCE, Marchesan MA, Pécora JD. Mechanism of action of sodium hypochlorite. Braz Dent J 2002;13(2):113-17.

Fish EW. An experimental investigation of enamel, dentine and pulp. London: John Bale, Sons and Danielsson Ltda; 1933.

Fogel HM, Pashley DH. Dentin permeability: effects of endodontic procedures on root slabs. J Endod 1990;16(9):442-5.

Fraser JG, Laws AJ. Chelating agents: their effect on the permeability of root canal dentin. Oral Surg Oral Med Oral Pathol 1976;41(4):534-40.

Fróis IM. Influência do conteúdo do sistema endodôntico na permeabilidade da dentina radicular, pós preparo do canal [Tese de Doutorado]. São Paulo: Faculdade de Odontologia da Universidade de São Paulo; 1999.

Galvan DA, Ciarlone AE, Pashley DH, Kulild JC, Primack PD, Simpson MD. Effect of smear layer removal on the diffusion permeability of human roots. $J$ Endod 1994;20(2):83-6.

García-Godoy F, Loushine RJ, Itthagarun A, Weller RN, Murray PE, Feilzer AJ, et al. Application of biologically-oriented dentin bonding principles to the use of endodontic irrigants. Am J Dent 2005;18(4):281-90.

Goldberg F, Abramovich A. Analysis of the effect of EDTA-C on the dentinal walls of the root canal. J Endod 1977;3(3):101-5.

Goldman M, Goldman L, Cavaleri R, Lin PS. The efficacy of several endodontic irrigating solutions: a scanning electron microscopic study: part 2. J Endod 1982;8(11):487-92.

Goldman LB, Goldman M, Kronman JH, Lin PS. The efficacy of several irrigating solutions for endodontics: a scanning electron microscopic study. Oral Surg Oral Med Oral Pathol 1981;52(2):197-204. 
Goldman M, Kronman JH, Goldman LB, Clausen H, Grady J. New method of irrigation during endodontic treatment. J Endod 1976;2(9):257-60.

Grempel M, Antoniazzi JH, Paiva JG. Determinação da permeabilidade dentinária radicular natural de dentes humanos anteriores, segundo a faixa etária e tipo de corante utilizado. Rev Paul Odontol 1990;12(1):4-14.

Guerisoli DM, Marchesan MA, Walmsley AD, Lumley PJ, Pécora JD. Evaluation of smear layer removal by EDTAC and sodium hypochlorite with ultrasonic agitation. Int Endod J 2002;35(5):418-21.

Guignes P, Faure J, Maurette A. Relationship between endodontic preparations and human dentin permeability measured in situ. J Endod 1996;22(2):60-7.

Gutiérrez JH, García J. Microscopic and macroscopic investigation on results of mechanical preparation of root canals. Oral Surg 1968;25(1):108-15.

Haapasalo M, Endal U, Zandi H, Coil JM. Eradication of endodontic infection by instrumentation and irrigation solutions. Endod Topics 2005;10:77-102.

Harrán Ponce E, Canalda Sahli C, Vilar Fernandes JA. Study of dentinal tubule architecture of permanent upper premolars: evaluation by SEM. Aust Endod J 2001;27(2):66-72.

Hulsmann M, Heckendorff M, Lennon A. Chelating agents in root canal treatment: mode of action and indications for their use. Int Endod J 2003;36(12):810-30.

Khademi A, Yazdizadeh M, Feizianfard M. Determination of the minimun instrumentation size for penetration of irrigants to the apical third of root canal systems. J Endod 2006;32(5):417-20.

Krause TA, Liewher FR, Hahn CL. The antimicrobial effect of MTAD, sodium hypochlorite, doxyxycline and citric acid on Enterococcus faecalis. J Endod 2007;33(1):28-30.

Lage-Marques JL, Antoniazzi JH. Versão eletrônica da Técnica Endodôntica da Faculdade de Odontologia da Universidade de São Paulo [CD-ROM]. São Paulo; 2002. 
Machnick TK, Torabinejad M, Munoz CA, Shabahang S. Effect of MTAD on flexural strength and modulus of elasticity of dentin. J Endod 2003;29(11):747-50.

Mader CL, Baumgartner JC, Peters DD. Scanning electron microscopic investigation of the smear layer on the root canals walls. J Endod 1984;10(10):477-83.

Marending M, Luder HU, Brunner TJ, Knecht S, Stark WJ, Zehnder M. Effect of sodium hypochlorite on human root dentine - mechanical, chemical and structural evaluation. Int Endod J 2007;40(10):786-93.

Marshall JF, Massler M, Dute HL. Effects of endodontic treatments on permeability of root dentine. Oral Surg 1960;13(2):208-23.

McComb D, Smith DC. A preliminary scanning electron microscopic study of root canals after endodontic procedures. J Endod 1975;1(7):238-42.

Mello I. Why should I remove smear layer after root canal instrumentation? How can I remove it? J Canad Dent Assoc 2006;72(8):713-14.

Mello I, Franco de Carvalho EMO, Ferreira MB, Robazza CRC. Análise qualitativa da limpeza da superfície dentinária de canais radiculares após irrigação com diferentes soluções. JBE 2007;7(27):266-71.

Mjör IA. Dentin-predentin complex and its permeability: pathology and treatment overview. J Dent Res 1985;64(nº espec):621-7.

Moura AAM. Análise in vitro da permeabilidade dentinária radicular quando do emprego de instrumentos endodônticos, tendo como fonte de variação o instrumento e o número de uso (contribuição ao estudo) [Tese de Doutorado]. São Paulo: Faculdade de Odontologia da USP; 1985.

Moura AAM, Prokopowitsch I, Aun CE, Lutfi Filho M. Análise in vitro da permeabilidade dentinária radicular em dentes instrumentados com e sem uso de EDTAC. Rev Paul Odontol 1988;10(6):18-24.

Nygaard-Østby B. Chelation in root canal therapy. Odontol Tidsk 1957;65:3-11. 
Ørstavik D, Haapasalo M. Disinfection by endodontic irrigants and dressings of experimentally infected dentinal tubules. Endod Dent Traumatol 1990;6(4):142-9.

Paiva JG, Antoniazzi JH. Endodontia - bases para a prática clínica. $2^{\mathrm{a}}$. ed. São Paulo: Artes Médicas; 1993.

Paiva JG, Antoniazzi JH. O uso de uma associação de peróxido de uréia e detergente (Tween 80 ) no preparo químico-mecânico dos canais radiculares. Rev Assoc Paul Cir Dent 1973;27(7):416-22.

Pascon FM, Kantovitz KR, Puppin-Rontani RM. Influence of cleansers and irrigation methods on primary and permanent root dentin permeability: a literature review. Braz J Oral Sci 2006;5(18):1063-9.

Pashley DH. Smear layer: Physiological considerations. Op Dent 1984;Suppl 3:1329.

Pashley DH, Livingston MJ. Effect of molecular size on permeability coefficients in human dentine. Arch Oral Biol 1978;23(5):391-5.

Pashley DH, Livingston MJ, Greenhill JD. Regional resistance of fluid flow in human dentine in vitro. Arch Oral Biol 1978;23(9):807-10.

Pashley DH, Michelich $\mathrm{V}$, Kehl T. Dentin permeability: effects of smear layer removal. J Prosthet Dent 1981;46(5): 531-7.

Pashley DH, Livingston MJ, Reeder OW, Horner J. Effect of the degree of tubules occlusion on the permeability of human dentin, in vitro. Arch Oral Biol 1978;23(12):1127-33.

Pécora JD. Contribuição ao estudo da permeabilidade dentinária radicular. Apresentação de um método histoquímico e análise morfométrica [Dissertação de Mestrado]. Ribeirão Preto: Faculdade de Odontologia de Ribeirão Preto da USP; 1985.

Pécora JD, Sousa Neto MD, Saquy PC, Silva RG, Cruz-Filho AM. Effect of Dakin's and EDTA solutions on dentin permeability of root canals. Braz Dent J 1993;4(2):7984. 
Portenier I, WaltimoT, Ørstavik D, Haapasalo M. Killing of Enterococcus faecalis by MTAD and chlorhexidine digluconate with or without Cetrimide in the Presence or Absence of Dentine Powder or BSA. J Endod 2006;32(2):138-41.

Prokopowitsch I, Moura AAM, Muench A. Análise in vitro da permeabilidade dentinária radicular do terço apical, tendo como fonte de variação a substância química auxiliar da instrumentação. Rev Odontol USP 1989;3(2):345-53.

Raldi DP, Lage-Marques JL. In vitro evaluation of the effects of the interaction between irrigating solutions, intracanal medication and Er:YAG laser in dentin permeability of the endodontic system. Pesqui Odontol Bras 2003;17(3):278-85.

Ribeiro RG. Estudo da permeabilidade dentinária das paredes dos canais radiculares instrumentados com diferentes soluções irrigantes, associadas ou não à irradiação de laser Er:YAG [Dissertação de Mestrado]. Ribeirão Preto: Faculdade de Odontologia de Ribeirão Preto da USP; 2001.

Robazza CRC. Avaliação in vitro da qualidade do selamento marginal apical segundo o tempo de aplicação da vibração intra-radicular ultrassônica durante a obturação dos canais radiculares [Tese de Titular]. Alfenas: Escola de Farmácia e Odontologia de Alfenas; 1991.

Robazza CRC. Contribuição in vitro da permeabilidade dentinária radicular quando do emprego de algumas substâncias de uso endodôntico [Tese de Doutorado]. Ribeirão Preto: Faculdade de Odontologia de Ribeirão Preto da USP; 1973.

Robazza CRC, Antoniazzi JH. Permeabilidade da dentina após o uso de substância de irrigação. Rev Fac Farm Odontol Rib Preto 1976;13(2):185-92.

Rode SM, Penna LAP, Cavalcanti BND. Desvendando os mistérios da polpa. In: Feller C; Gorab R. Atualização na clínica odontológica. São Paulo: Artes Médicas; 2000. v. 1. p.92-130.

Rossi-Fedele G, Roberts AP. A preliminary study investigating the survival of tetracycline resistant Enterococcus faecalis after root canal irrigation with high concentrations of tetracycline. Int Endod Journal 2007;40(10):772-77. 
Scelza, MFZ. Análise pela microscopia eletrônica de varredura da limpeza das paredes dos canais radiculares segundo as substâncias irrigadoras de acordo com três diferentes técnicas [Tese de Doutorado]. São Paulo: Faculdade de Odontologia da USP; 1998.

Scelza MF, Antoniazzi JH, Scelza P. Efficacy of final irrigation - a scanning electron microscopic evaluation. J Endod 2000;26(6):355-8.

Scelza MF, Teixeira AM, Scelza P. Decalcifying effect of EDTA-T, 10\% citric acid, and $17 \%$ EDTA on root canal dentin. Oral Surg Oral Med Oral Pathol Oral Radiol Endod 2003;95(2):234-6

Scelza MF, Pierro V, Scelza P. Effect of three different time periods of irrigation with EDTA-T, EDTA and citric acid on smear layer removal. Oral Surg Oral Med Oral Pathol Oral Radiol Endod 2004;98(4):499-503.

Sedgley CM, Nagel AC, Hall D, Applegate B. Influence of irrigant needle depth in removing bioluminescent bacteria inoculated into instrumented root canals using realtime imaging in vitro. Int Endod J 2005;38(2):97-104.

Seltzer S, Bender IB. The Dental Pulp: biological considerations in dental procedures. 2 ed. Philadelphia: Lippincot; 1975.

Shabahang S, Torabinejad M. Effect of MTAD on Enterococcus faecalis contaminated root canals of extracted human teeth. J Endod 2003;29(9):576-9.

Spanó JC, Barbin EL, Santos TC, Guimarães LF, Pécora JD. Solvent action of sodium hypochlorite on bovine pulp and physico-chemical properties of resulting liquid. Braz Dent J 2001;12(3):154-7.

Takeda FH, Harashima T, Kimura Y, Matsumoto K. A comparative study of the removal of smear layer by three endodontic irrigants and two types of laser. Int Endod J 1999;32(1):32-9.

Tao L, Anderson RW, Pashley DH. Effect of endodontic procedures on root dentin permeability. J Endod 1991;17(12):583-8.

Tay FR, Pashley DH, Loushine RJ, Doyle MD, Gillespie WT, Weller RN, et al. Ultrastructure of smear layer-covered intraradicular dentin after irrigation with BioPure MTAD. J Endod 2006;32(3):218-21. 
Teixeira CS, Felippe MC, Felippe WT. The effect of application time of EDTA and $\mathrm{NaOCl}$ on intracanal smear layer removal: an SEM analysis. Int Endod J 2005;38(5):285-90.

Torabinejad M, Handysides R, Khademi AA, Bakland LK. Clinical implications of the smear layer in Endodontics: a review. Oral Surg Oral Med Oral Pathol Oral Radiol Endod 2002;94(6):658-66.

Torabinejad M, Cho Y, Khademi AA, Bakland LK, Shabahang S. The effect of various concentrations of sodium hypochlorite on the ability of MTAD to remove the smear layer. J Endod 2003a;29(4):233-9.

Torabinejad M, Khademi AA, Babagoli J, Cho Y, Johnson WB, Bozhilov K, et al. A new solution for the removal of the smear layer. J Endod 2003b;29(3):170-5.

Torabinejad M, Shabahang S, Bahjri K. Effect of MTAD on postoperative discomfort: a randomized clinical trial. J Endod 2005;31(3):171-6.

Tsukuda N, Gabler WL. The influence of doxycycline on the attachment of fibroblasts to gelatin-coated surfaces and its cytotoxicity. J Periodontol 1993;64(12):1219-24.

Universidade de São Paulo. Faculdade de Odontologia de Ribeirão Preto. Departamento de Dentística Restauradora. Temas de Endodontia. Disponível em http://www.forp.usp.br/restauradora/temas_endo/solu/solu.htm [3 nov. 2004].

Whittaker DK, Kneale MJ. The dentine-predentine interface in human teeth. A scanning electron microscopy study. Br Dent J 1979;146(2):43-6.

Yamada RS, Armas A, Goldman M, Lin PS. A Scanning electron microscopic comparison of a high volume final flush with several irrigating solutions: part 3. J Endod 1983;9(4):137:42.

Yamashita JC, Tanomaru Filho M, Leonardo MR, Rossi MA, Silva LA. Scanning electron microscopic study of the chelating ability of chlorexidine as a root canal irrigant. Int Endod J 2003;36(6):391-4.

Yang SE, Bae KS. Scanning electron microscopy study of the adhesion of Prevotella nigrescens to the dentin of prepared root canals. J Endod 2002;28(6):433-7. 
Yoshida T, Shibata T, Shinohara T, Gomyo S, Sekine I. Clinical evaluation of the efficacy of EDTA solution as an endodontic irrigant. J Endod 1995;21(12):592-3.

Zehnder M. Root canal irrigants. J Endod 2006;32(5):389-98.

Zinng P, Sakura C, Moura AAM. Avaliação in vitro da eficiência na remoção do magma dentinário da parede radicular através de microscopia eletrônica de varredura, após irrigação com diferentes soluções ativadas por ultra-som. Rev Cienc Saúde 1997;15(1):15-22.

Zuolo M, Murgel CAF, Pécora JD, Antoniazzi JH, Costa WF. Ação do EDTA e suas associações com tensoativos na permeabilidade da dentina radicular. Rev Odontol USP 1987;1(4):18-23. 
APÊNDICE A - Dados originais e médias em percentual da penetração do corante na massa dentinária dos grupos testados e nos seus terços radiculares

\begin{tabular}{|c|c|c|c|c|c|}
\hline$\overbrace{\text { TERÇOS }}^{\text {GRUPOS }}$ & I & II & III & IV & MÉDIAS \\
\hline CERVICAL & $\begin{array}{l}36,35 \\
67,86 \\
53,54 \\
43,67 \\
56,43 \\
44,78 \\
40,11 \\
59,60 \\
42,96\end{array}$ & $\begin{array}{l}48,00 \\
44,41 \\
36,40 \\
51,05 \\
48,31 \\
74,41 \\
84,73 \\
48,01 \\
38,58\end{array}$ & $\begin{array}{l}26,84 \\
59,23 \\
69,21 \\
52,01 \\
44,66 \\
34,93 \\
52,65 \\
84,56 \\
35,30\end{array}$ & $\begin{array}{l}46,48 \\
61,24 \\
43,26 \\
44,23 \\
61,36 \\
47,33 \\
56,99 \\
47,51 \\
57,11 \\
36,85\end{array}$ & $\begin{array}{l}- \\
- \\
- \\
- \\
- \\
- \\
- \\
- \\
- \\
-\end{array}$ \\
\hline Médias do terço cervical & 49,48 & 52,65 & 51,04 & 50,24 & 50,85 \\
\hline MÉDIO & $\begin{array}{l}31,23 \\
52,33 \\
51,59 \\
14,52 \\
74,34 \\
35,28 \\
59,26 \\
55,57 \\
53,48\end{array}$ & $\begin{array}{l}34,28 \\
23,04 \\
56,90 \\
55,57 \\
46,35 \\
62,78 \\
50,24 \\
40,22 \\
46,45\end{array}$ & $\begin{array}{l}28,95 \\
39,03 \\
59,65 \\
40,83 \\
17,23 \\
41,37 \\
79,64 \\
44,52 \\
39,03\end{array}$ & $\begin{array}{l}61,70 \\
52,58 \\
56,32 \\
35,40 \\
47,81 \\
39,56\end{array}$ & $\begin{array}{l}- \\
- \\
- \\
- \\
- \\
- \\
- \\
- \\
-\end{array}$ \\
\hline Médias do terço médio & 47,51 & 46,20 & 43,36 & 48,89 & 46,49 \\
\hline APICAL & $\begin{array}{l}46,17 \\
46,54 \\
44,09 \\
30,85 \\
21,76 \\
41,02 \\
45,22 \\
32,11 \\
12,93\end{array}$ & $\begin{array}{l}24,09 \\
49,51 \\
29,06 \\
45,16 \\
56,93 \\
38,84 \\
34,32 \\
27,05\end{array}$ & $\begin{array}{l}10,86 \\
11,20 \\
13,52 \\
43,34 \\
26,90 \\
32,79 \\
11,34 \\
23,33\end{array}$ & $\begin{array}{l}38,65 \\
27,87 \\
26,64 \\
54,22 \\
23,04 \\
47,51 \\
33,07 \\
48,77 \\
15,95\end{array}$ & $\begin{array}{l}- \\
- \\
- \\
- \\
- \\
- \\
- \\
- \\
-\end{array}$ \\
\hline $\begin{array}{c}\text { Médias do terço apical } \\
\text { MÉDIAS }\end{array}$ & $\begin{array}{c}35,63 \\
44,210\end{array}$ & $\begin{array}{l}38,12 \\
45,95\end{array}$ & $\begin{array}{l}21,66 \\
39,34\end{array}$ & $\begin{array}{l}35,08 \\
44,46\end{array}$ & 32,62 \\
\hline
\end{tabular}


APÊNDICE B - Teste de aderência à curva normal (D'Agostino) dos grupos avaliados para o estudo da permeabilidade dentinária

\begin{tabular}{|c|c|c|c|c|}
\hline Resultados & $\bar{I}$ & II & III & IV \\
\hline Tamanho da amostra & 27 & 26 & 26 & 25 \\
\hline D (Desvio) & 0,2803 & 0,2723 & 0,2806 & 0,2813 \\
\hline $\begin{array}{r}\text { Valores críticos } 5 \% \\
P=\end{array}$ & $\begin{array}{c}0,2651 \text { a } 0,2866 \\
p>0,05^{\mathrm{ns}}\end{array}$ & $\begin{array}{c}0,2647 \text { a } 0,2866 \\
p>0,05^{\text {ns }}\end{array}$ & $\begin{array}{c}0,2647 \text { a } 0,2866 \\
p>0,05^{\text {ns }}\end{array}$ & $\begin{array}{c}0,2643 \text { a } 0,2866 \\
p>0,05^{\text {ns }}\end{array}$ \\
\hline
\end{tabular}

ns $=$ não significante 
APÊNDICE C - Parâmetros amostrais dos valores absolutos percentuais da penetração do corante segundo os grupos experimentais e os terços radiculares

\begin{tabular}{|c|c|c|c|c|c|c|c|c|c|c|c|c|}
\hline & GI cerv & GI méd & GI apic & GII cerv & GII méd & GII apic & GIII cerv & GIII méd & GIII apic & $\begin{array}{l}\text { GIV } \\
\text { cerv }\end{array}$ & $\begin{array}{l}\text { GIV } \\
\text { méd }\end{array}$ & GIV apic \\
\hline $\begin{array}{l}\text { Tamanho } \\
\text { da } \\
\text { amostra }\end{array}$ & 9 & 9 & 9 & 9 & 9 & 8 & 9 & 9 & 8 & 10 & 6 & 9 \\
\hline $\begin{array}{l}\text { Valor } \\
\text { Mínimo }\end{array}$ & 36,35 & 14,52 & 12,93 & 36,40 & 23,04 & 24,09 & 26,84 & 17,23 & 10,86 & 36,85 & 35,40 & 15,95 \\
\hline $\begin{array}{l}\text { Valor } \\
\text { Máximo }\end{array}$ & 67,86 & 74,34 & 46,54 & 84,73 & 62,78 & 56,93 & 84,56 & 79,64 & 43,34 & 61,36 & 61,70 & 54,22 \\
\hline $\begin{array}{l}\text { Amplitude } \\
\text { Total }\end{array}$ & 31,51 & 59,82 & 33,61 & 48,33 & 39,74 & 32,84 & 57,72 & 62,41 & 32,48 & 24,51 & 26,30 & 38,27 \\
\hline Mediana & 44,78 & 52,33 & 41,02 & 48,01 & 46,45 & 36,58 & 52,01 & 40,83 & 18,42 & 47,42 & 50,19 & 33,07 \\
\hline $\begin{array}{l}\text { Média } \\
\text { Aritmética }\end{array}$ & 49,48 & 47,51 & 35,63 & 52,65 & 46,20 & 38,12 & 51,04 & 43,36 & 21,66 & 50,24 & 48,89 & 35,08 \\
\hline Variância & 107,95 & 312,67 & 145,70 & 262,14 & 150,98 & 135,65 & 332,25 & 315,15 & 146,14 & 70,18 & 100,62 & 169,90 \\
\hline $\begin{array}{l}\text { Desvio } \\
\text { Padrão }\end{array}$ & 10,39 & 17,68 & 12,07 & 16,19 & 12,29 & 11,65 & 18,23 & 17,75 & 12,09 & 8,38 & 10,03 & 13,03 \\
\hline $\begin{array}{l}\text { Erro } \\
\text { Padrão } \\
\end{array}$ & 3,46 & 5,89 & 4,02 & 5,40 & 4,09 & 4,18 & 6,076 & 5,92 & 4,27 & 2,65 & 4,09 & 4,34 \\
\hline
\end{tabular}


APÊNDICE D - ANOVA e teste de Tukey para os grupos e diferentes terços avaliados, para o estudo da permeabilidade dentinária

\begin{tabular}{|c|c|c|c|}
\hline FONTES DE VARIAÇÃO & 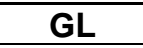 & SQ & QM \\
\hline Tratamentos & 11 & 7669,867 & 697,261 \\
\hline Erro & 92 & 17481,057 & 190,012 \\
\hline $\mathrm{F}=$ & 3,6696 & & \\
\hline$(p)=$ & 0,0004 & & \\
\hline Média grupo I - cervical = & 49,4778 & & \\
\hline Média grupo I - médio = & 47,5111 & & \\
\hline Média grupo I - apical = & 35,6322 & & \\
\hline Média grupo II - cervical = & 52,6556 & & \\
\hline Média grupo II - médio = & 46,2033 & & \\
\hline Média grupo II - apical = & 38,1200 & & \\
\hline Média grupo III - cervical = & 51,0433 & & \\
\hline Média grupo III - médio = & 43,3611 & & \\
\hline Média grupo III - apical = & 21,6600 & & \\
\hline Média grupo IV - cervical = & 50,2360 & & \\
\hline Média grupo IV - médio = & 48,8950 & & \\
\hline Média grupo IV - apical = & 35,0800 & & \\
\hline Tukey: & Q & (p) & \\
\hline Médias (I - cervical a I - médio) = & 0,4280 & $>0,05$ & ns \\
\hline Médias $(I-$ cervical a I - apical $)=$ & 3,0133 & $>0,05$ & ns \\
\hline Médias $(\mathrm{I}$ - cervical a $\mathrm{II}$ - cervical $)=$ & 0,6916 & $>0,05$ & ns \\
\hline Médias $(\mathrm{I}$ - cervical a III - cervical $)=$ & 0,3407 & $>0,05$ & ns \\
\hline Médias $(\mathrm{I}$ - cervical a IV - cervical) $=$ & 0,1693 & $>0,05$ & ns \\
\hline Médias $(\mathrm{I}-$ médio a $\mathrm{I}-$ apical $)=$ & 2,5853 & $>0,05$ & ns \\
\hline Médias (I - médio a II - médio) = & 0,2846 & $>0,05$ & ns \\
\hline Médias (I - médio a III - médio) = & 0,9032 & $>0,05$ & ns \\
\hline Médias (I - médio a IV - médio) = & 0,2694 & $>0,05$ & ns \\
\hline Médias (I - apical a II - apical) = & 0,5253 & $>0,05$ & ns \\
\hline Médias (I - apical a III - apical) = & 2,9501 & $>0,05$ & ns \\
\hline Médias (I - apical a IV - apical) = & 0,1202 & $>0,05$ & ns \\
\hline Médias (II - cervical a II - médio) = & 1,4042 & $>0,05$ & ns \\
\hline Médias (II - cervical a II - apical) = & 3,0690 & $>0,05$ & ns \\
\hline Médias $(\mathrm{II}$ - cervical a III - cervical) = & 0,3509 & $>0,05$ & ns \\
\hline Médias (II - cervical a IV - cervical) = & 0,5403 & $>0,05$ & ns \\
\hline Médias (II - médio a II - apical) = & 1,7067 & $>0,05$ & ns \\
\hline Médias (II - médio a III - médio) = & 0,6186 & $>0,05$ & ns \\
\hline Médias (II - médio a IV - médio) = & 0,5240 & $>0,05$ & ns \\
\hline Médias (II - apical a III - apical) = & 3,3774 & $>0,05$ & ns \\
\hline Médias (II - apical a IV - apical) = & 0,6419 & $>0,05$ & ns \\
\hline Médias (III - cervical a III - médio) = & 1,6719 & $>0,05$ & ns \\
\hline Médias (III - cervical a III - apical) = & 6,2039 & $<0,05$ & $\mathrm{~s}$ \\
\hline Médias (III - cervical a IV - cervical) = & 0,1803 & $>0,05$ & ns \\
\hline Médias (III - médio a III - apical) = & 4,5819 & $<0,05$ & $\mathrm{~s}$ \\
\hline Médias (III - médio a IV - médio) = & 1,0772 & $>0,05$ & ns \\
\hline Médias (III - apical a IV - apical) = & 2,8335 & $>0,05$ & ns \\
\hline Médias (IV - cervical a IV - médio) = & 0,2664 & $>0,05$ & ns \\
\hline Médias (IV - cervical a IV - apical) = & 3,3842 & $<0,05$ & $\mathrm{~s}$ \\
\hline Médias (IV - médio a IV - apical) = & 2,6892 & $>0,05$ & ns \\
\hline
\end{tabular}

ns = não significante $\mathbf{s}=$ significante 
APÊNDICE E - Dados originais dos escores obtidos quanto à remoção do magma dentinário dos grupos testados

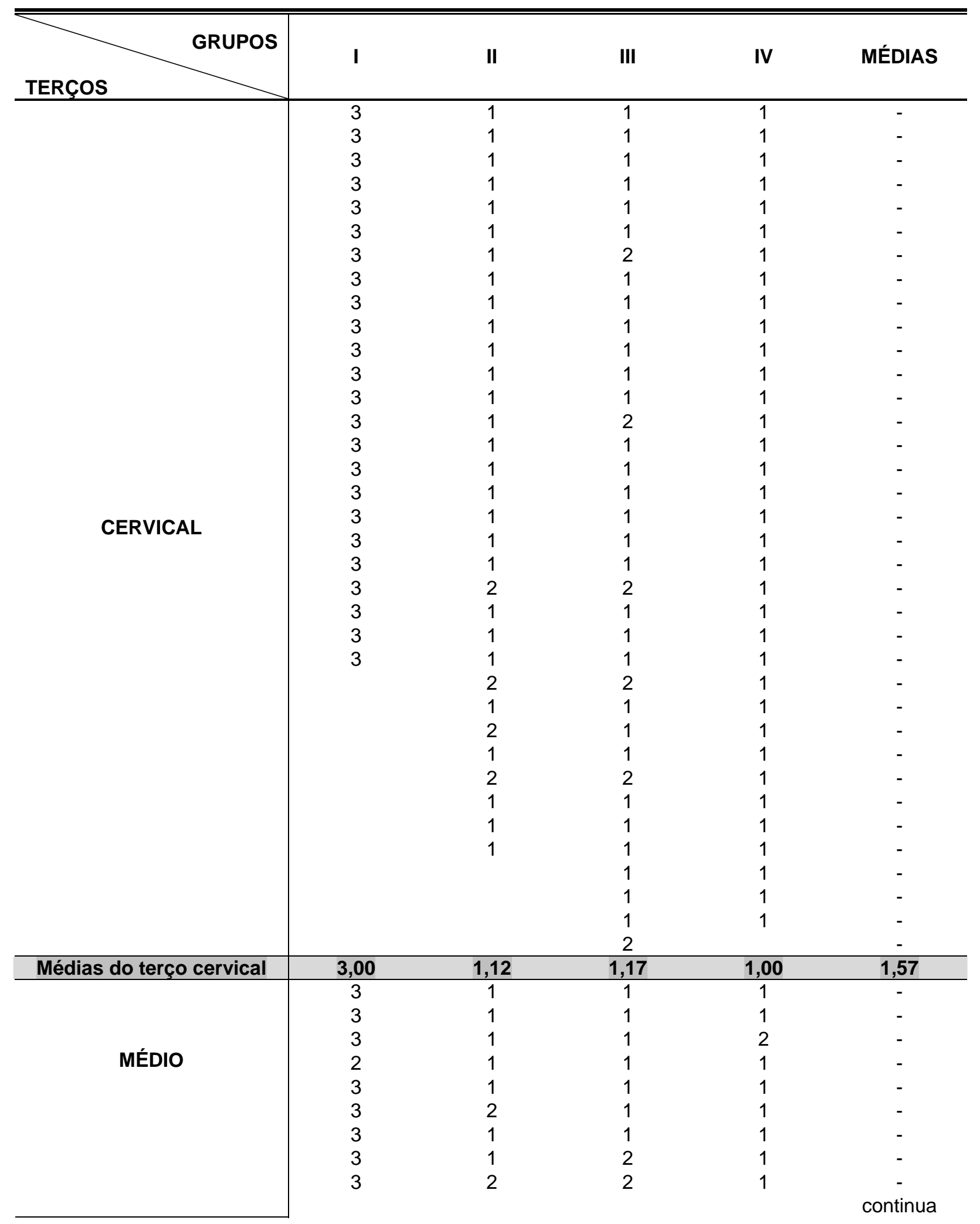




\begin{tabular}{|c|c|c|c|c|c|}
\hline continuação & $\begin{array}{l}3 \\
2 \\
3 \\
3 \\
2 \\
3 \\
3 \\
3 \\
3 \\
3 \\
3 \\
2 \\
3 \\
3 \\
2 \\
3 \\
3 \\
3 \\
3 \\
3 \\
3\end{array}$ & $\begin{array}{l}1 \\
2 \\
1 \\
1 \\
1 \\
2 \\
1 \\
1 \\
1 \\
1 \\
1 \\
1 \\
1 \\
2 \\
1 \\
2 \\
1 \\
2 \\
1 \\
1 \\
1 \\
2 \\
1\end{array}$ & $\begin{array}{l}2 \\
1 \\
1 \\
1 \\
1 \\
1 \\
1 \\
2 \\
1 \\
1 \\
2 \\
1 \\
1 \\
1 \\
1 \\
1 \\
1 \\
1 \\
2 \\
2 \\
2 \\
1 \\
1 \\
1 \\
1 \\
1 \\
1\end{array}$ & $\begin{array}{l}1 \\
1 \\
1 \\
1 \\
1 \\
2 \\
1 \\
1 \\
1 \\
1 \\
1 \\
1 \\
1 \\
1 \\
1 \\
1 \\
1 \\
2 \\
1 \\
1 \\
1 \\
1 \\
1 \\
1 \\
1 \\
1\end{array}$ & $\begin{array}{l}- \\
- \\
- \\
- \\
- \\
- \\
- \\
- \\
- \\
- \\
- \\
- \\
- \\
- \\
- \\
- \\
- \\
- \\
- \\
- \\
- \\
- \\
- \\
- \\
- \\
-\end{array}$ \\
\hline Médias do terço médio & 2,83 & 1,25 & 1,22 & 1,08 & 1,60 \\
\hline APICAL & $\begin{array}{l}2 \\
3 \\
3 \\
3 \\
3 \\
3 \\
3 \\
3 \\
3 \\
3 \\
3 \\
3 \\
3 \\
3 \\
3 \\
3 \\
3 \\
3\end{array}$ & $\begin{array}{l}2 \\
2 \\
1 \\
2 \\
1 \\
3 \\
2 \\
2 \\
2 \\
1 \\
1 \\
1 \\
3 \\
2 \\
2 \\
3 \\
2 \\
1 \\
1 \\
3 \\
3 \\
2 \\
2 \\
2 \\
1\end{array}$ & $\begin{array}{l}1 \\
1 \\
2 \\
1 \\
1 \\
1 \\
3 \\
2 \\
2 \\
2 \\
2 \\
3\end{array}$ & $\begin{array}{l}1 \\
2 \\
1 \\
2 \\
2\end{array}$ & $\begin{array}{c}- \\
- \\
- \\
- \\
- \\
- \\
- \\
- \\
- \\
- \\
- \\
- \\
- \\
- \\
- \\
- \\
- \\
- \\
- \\
- \\
- \\
- \\
- \\
- \\
- \\
\text { continua }\end{array}$ \\
\hline
\end{tabular}




\begin{tabular}{c|ccccc} 
conclusão & & 3 & 1 & 2 & - \\
& & 2 & 1 & 1 & - \\
& & 2 & 2 & - \\
& & 2 & 2 & - \\
& & 1 & 1 & - \\
& & 1 & 2 & - \\
& & 1 & 2 & - \\
& & 1 & & - \\
\hline Médias do terço apical & & 1 & & 1,88 \\
\hline MÉDIAS & 2,94 & 1 & 1 & & 1,68 \\
\hline \hline
\end{tabular}


APÊNDICE F - Teste de aderência à curva normal (D'Agostino) dos grupos avaliados para o estudo da remoção do magma dentinário

\begin{tabular}{r|cccc}
\hline \hline Resultados & I & II & III & IV \\
\hline Tamanho da amostra & 72 & 69 & 108 & 94 \\
D (Desvio) & 0,1446 & 0,2227 & 0,2059 & 0,1222 \\
Valores críticos 5\% & 0,2728 a 0,28630 & 0,2725 a 0,2865 & 0,2748 a 0,2859 & 0,2742 a 0,2861 \\
$P=$ & $p<0,05^{\mathbf{s}^{\mathbf{s}}}$ & $\mathrm{p}<0,05^{\mathrm{s}}$ & $\mathrm{p}<0,05^{\mathrm{s}}$ & $\mathrm{p}<0,05^{\mathrm{s}}$ \\
\hline \hline
\end{tabular}

s = significante 
APÊNDICE G - Parâmetros amostrais dos escores absolutos da presença de magma dentinário segundo os terços radiculares e tratamentos realizados

\begin{tabular}{|c|c|c|c|c|c|c|c|c|c|c|c|c|}
\hline & GI cerv & GI méd & GI apic & $\begin{array}{c}\text { GII } \\
\text { cerv }\end{array}$ & $\begin{array}{c}\text { GII } \\
\text { méd }\end{array}$ & $\begin{array}{c}\text { GII } \\
\text { apic }\end{array}$ & $\begin{array}{l}\text { GIII } \\
\text { cerv }\end{array}$ & $\begin{array}{l}\text { GIII } \\
\text { méd }\end{array}$ & $\begin{array}{l}\text { GIII } \\
\text { apic }\end{array}$ & $\begin{array}{l}\text { GIV } \\
\text { cerv }\end{array}$ & $\begin{array}{l}\text { GIV } \\
\text { méd }\end{array}$ & $\begin{array}{l}\text { GIV } \\
\text { apic }\end{array}$ \\
\hline Tamanho da amostra & 24 & 30 & 18 & 32 & 32 & 27 & 36 & 36 & 47 & 47 & 44 & 32 \\
\hline Valor Mínimo & 3,00 & 2,00 & 2,00 & 1,00 & 1,00 & 1,00 & 1,00 & 1,00 & 1,00 & 1,00 & 1,00 & 1,00 \\
\hline Valor Máximo & 3,00 & 3,00 & 3,00 & 2,00 & 2,00 & 3,00 & 2,00 & 2,00 & 3,00 & 2,00 & 2,00 & 2,00 \\
\hline Amplitude Total & 0,00 & 1,00 & 1,00 & 1,00 & 1,00 & 2,00 & 1,00 & 1,00 & 2,00 & 1,00 & 1,00 & 1,00 \\
\hline Mediana & 3,00 & 3,00 & 3,00 & 1,00 & 1,00 & 2,00 & 1,00 & 1,00 & 1,00 & 1,00 & 1,00 & 1,00 \\
\hline Média Aritmética & 3,00 & 2,83 & 2,94 & 1,12 & 1,25 & 1,92 & 1,17 & 1,22 & 1,39 & 1,00 & 1,08 & 1,25 \\
\hline
\end{tabular}


APÊNDICE H - Teste de Kruskal-Wallis para os grupos e diferentes terços avaliados, para o estudo da remoção do magma dentinário

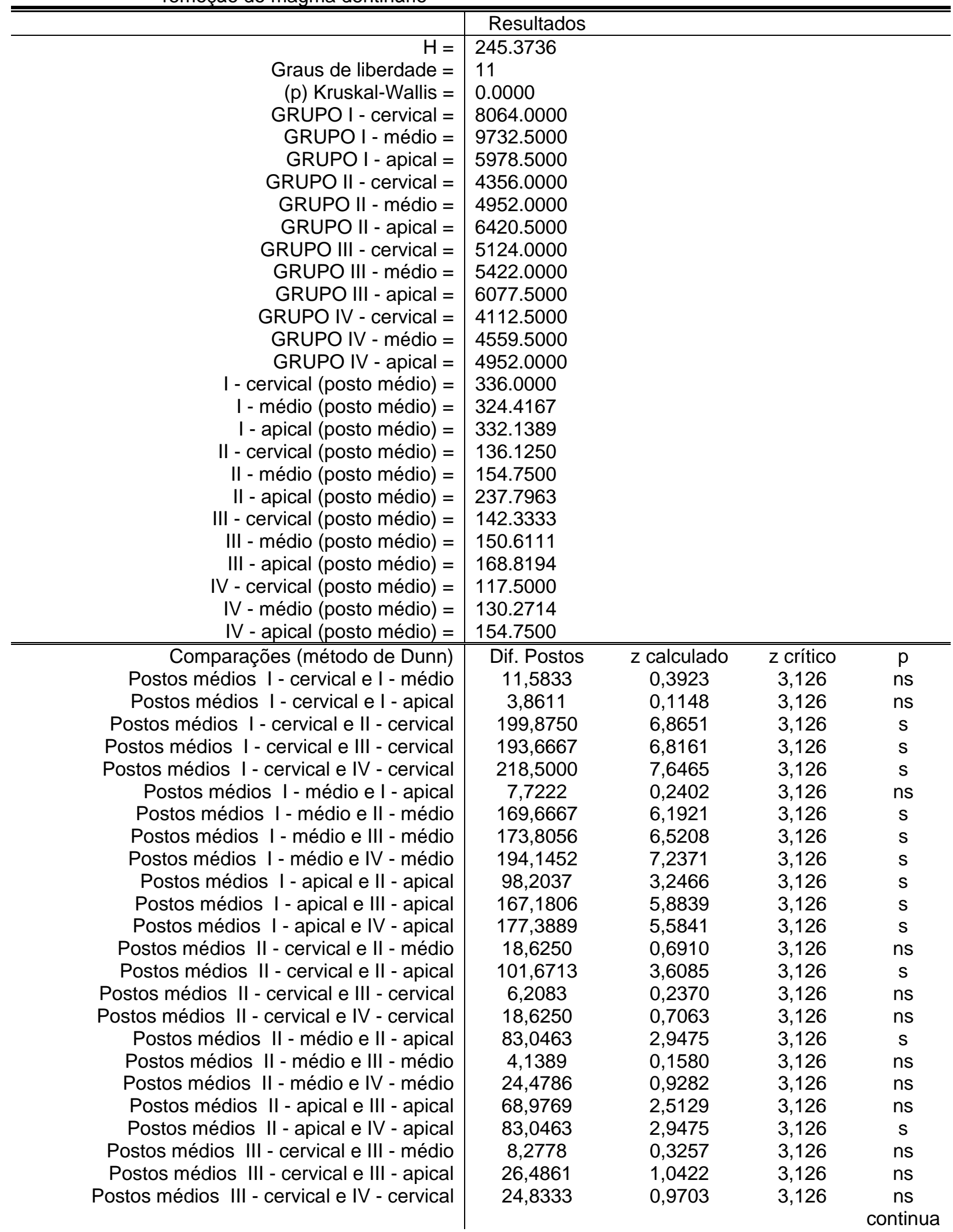




\begin{tabular}{r|rrrr} 
continuação & & & & \\
Postos médios III - médio e III - apical & 18,2083 & 0,7165 & 3,126 & $\mathrm{~ns}$ \\
Postos médios III - médio e IV - médio & 20,3397 & 0,7947 & 3,126 & $\mathrm{~ns}$ \\
Postos médios III - apical e IV - apical & 14,0694 & 0,5371 & 3,126 & $\mathrm{~ns}$ \\
Postos médios IV - cervical e IV - médio & 12,7714 & 0,4955 & 3,126 & $\mathrm{~ns}$ \\
Postos médios IV - cervical e IV - apical & 37,2500 & 1,4125 & 3,126 & $\mathrm{~ns}$ \\
Postos médios IV - médio e IV - apical & 24,4786 & 0,9282 & 3,126 & $\mathrm{~ns}$ \\
\hline \hline
\end{tabular}

ns = não significante $\mathbf{s}=$ significante 
APÊNDICE I - Estudo da correlação linear de Pearson para as médias dos grupos da infiltração do corante e da remoção do magma dentinário

\begin{tabular}{l|l}
\hline \hline $\mathrm{n}$ (pares) & 4 \\
$\mathrm{r}$ (Pearson) & $-0,10$ \\
IC 95\% & $-0,97$ a 0,95 \\
IC 99\% & $-0,99$ a 0,99 \\
R2 & 0,11 \\
$\mathrm{t}$ & $-0,15$ \\
$\mathrm{GL}$ & 2 \\
$(\mathrm{p})$ & 0,89 \\
\hline \hline
\end{tabular}

APÊNDICE J - Estudo da correlação linear de Pearson entre as médias dos terços para a infiltração do corante e da remoção do magma dentinário

\begin{tabular}{l|l}
\hline \hline $\mathrm{n}$ (pares) & 12 \\
$\mathrm{r}$ (Pearson) & $-0,08$ \\
IC 95\% & $-0,63$ a 0,51 \\
IC 99\% & $-0,74$ a 0,65 \\
R2 & 0,01 \\
$\mathrm{t}$ & $-0,27$ \\
$\mathrm{GL}$ & 10 \\
$(\mathrm{p})$ & 0,80 \\
\hline \hline
\end{tabular}


ANEXO A - Parecer do Comitê de Ética em Pesquisa

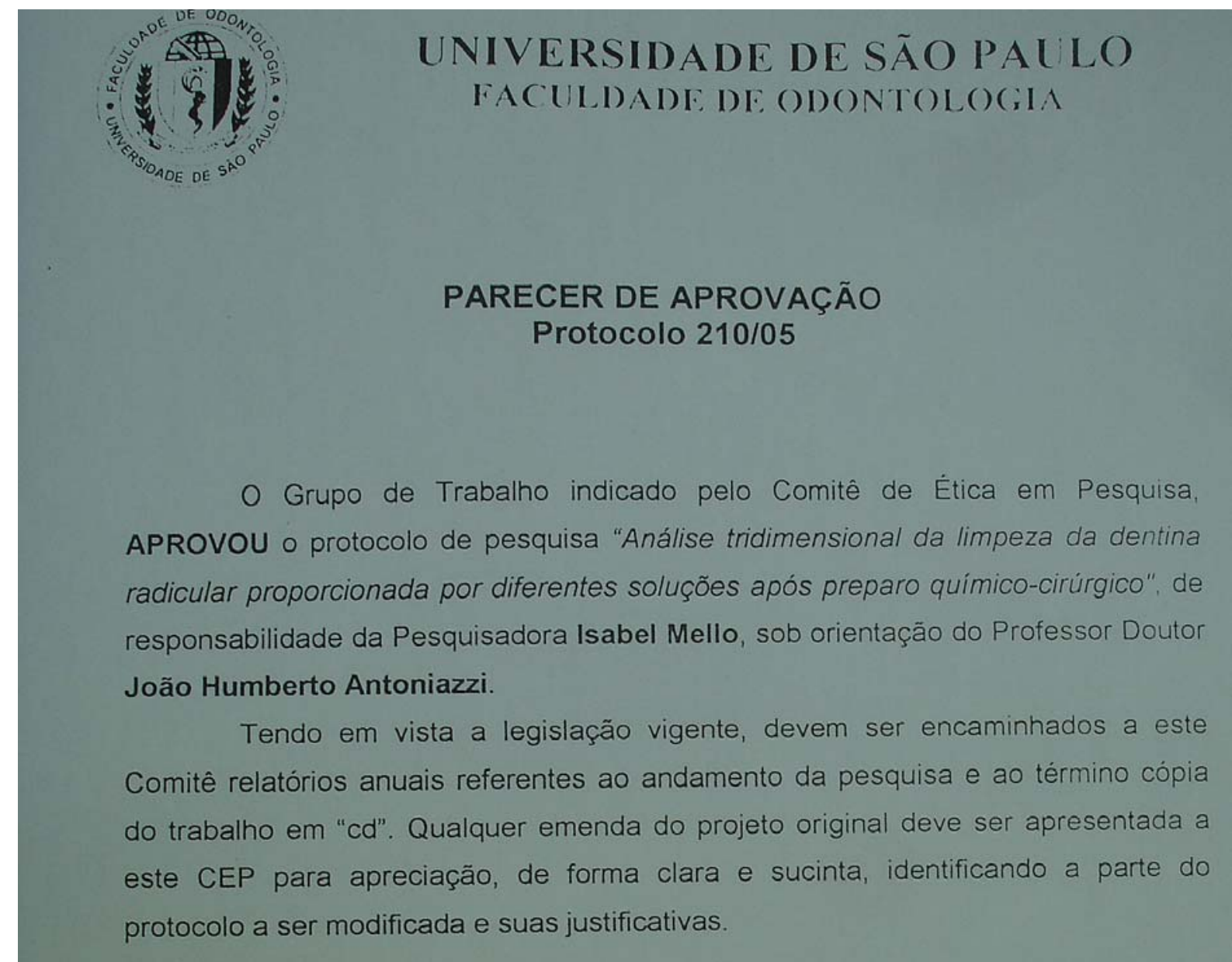

São Paulo, 07 de dezembro de 2005

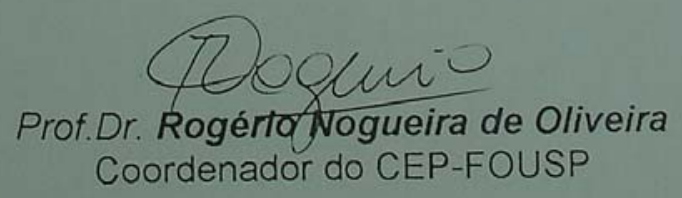

Av P'ot 1 meu Prestes. 2227 - Cidade Unversitana Ammando de Silles Olivena CFP 0550800 Sao Paulo Si' Diretoria Telefax $(011) 3091.006213091-7817 / 30917860$. Compras $(011,3091$ - 